\title{
PROBOSCIDEA-SANDERS
}

\section{Proboscidea from the Baynunah Formation}

\author{
William J. Sanders
}

Museum of Paleontology, University of Michigan, 1109 Geddes Avenue, Ann Arbor, Michigan 48109-1079, USA. wsanders@umich.edu

\begin{abstract}
The Baynunah Formation provides the only late Miocene record of fossil proboscideans from the Arabian Peninsula, identifiable as a deinothere, tetralophodont gomphothere(s), and stegotetrabelodont elephant. Ichnofossils show the oldest evidence for modern-type elephant herd structure. The elephant sample is particularly abundant, and newly-recovered fossils yield critical evidence about their systematics and biology. Comparative results show that the Baynunah stegotetrabelodont belongs in a new species, and that in many ways it is the most primitive of all elephants — supporting a geological age of 8.0-6.0 Ma—consistent with having evolved in Afro-Arabia from Tetralophodon between 9.0-8.0 Ma. Body size analyses reveal that these elephants were exceptionally tall and heavy, possibly exceeding 10,000 kg. Tooth emergence is reconstructed as dp2-dp3-dp4-p3-m1-p4$\mathrm{m} 2-\mathrm{m} 3$. The taxonomic composition and dietary preferences of the Baynunah proboscideans indicate the presence of heterogeneous local habitats in the region during the late Miocene, though the high abundance of the stegotetrabelodont, and the rarity of the deinothere and gomphothere(s) indicate a dominance of grassland habitats and a lesser representation of wooded areas.
\end{abstract}

Keywords - Baynunah Formation; United Arab Emirates; Arabian Peninsula; proboscideans; stegotetrabelodont elephants; tetralophodont gomphotheres; deinotheres; late Miocene

Running Head-Proboscidea 


\section{PROBOSCIDEA-SANDERS}

\section{INTRODUCTION}

Vertebrate fossils from Baynunah Formation localities in western Abu Dhabi Emirate, United Arab Emirates, recovered since the 1940s, include the only reported late Miocene terrestrial mammals from the Arabian Peninsula (Whybrow et al. 1990; Hill 1999; Whybrow and Clements 1999; Hill et al. 2012; Bibi et al. 2013). This taxonomically diverse mammalian assemblage, comprising rodents, soricids, carnivores, perissodactyls, cetartiodactyls, primates, and proboscideans, provides robust evidence for investigation of faunal evolution, biogeography, and paleoecology in the region during the time of its accumulation (Hill and Gundling 1999; Stewart 2005; Hill et al. 2012; Bibi et al. 2013; Gilbert et al. 2014). Localities of the Baynunah Formation are largely dated through biochronological correlation to 8.0-6.0 Ma—probably 7.7 -7.0 Ma (Peppe et al. this volume) — and the fauna is thought to indicate geographic connections with East Africa and, to a lesser extent, South Asia (Bibi et al. 2013; Bibi et al. this volume-a). Along with its extraordinary importance for comprehending the ancient ecology of the Arabian Peninsula, the Baynunah Formation has wider significance as one of only a handful of Afro-Arabian sedimentary sequences and sites preserving evidence of mammalian evolution during the 8.0-6.0 Ma interval. The late Miocene encompassed an especially dynamic episode of ecological change and faunal turnover that led to the establishment of many modern taxa (notably including hominins), documented at Lothagam, Tugen Hills, and Lemudong'o, Kenya, Toros-Menalla, Chad, Sahabi, Libya, and the western margin sites of the Middle Awash, Ethiopia (Hill et al. 1985; Cerling et al. 1993, 1997; Leakey et al. 1996; Hill 1999; Wolde-Gabriel et al. 2001; Kingston et al. 2002; Vignaud et al. 2002; Ambrose et al. 2003; Leakey and Harris 2003; Boaz et al. 2008). 


\section{PROBOSCIDEA-SANDERS}

Previous studies have been made of the individual mammalian groups occurring in the Baynunah Formation (e.g., de Bruijn and Whybrow 1994; Barry 1999; Bishop and Hill 1999; de Bruijn 1999; Eisenmann and Whybrow 1999; Gentry 1999a, b; Hill and Grundling 1999; Boisserie 2005; Kraatz et al. 2009; Gilbert et al. 2014; Boisserie et al. 2017; see also other chapters in this volume). Proboscidean fossils are particularly well represented in the mammalian assemblage and have been known since geological and paleontological survey of the area in the 1960s. The first proboscidean specimen from the Baynunah Formation, discovered during geological exploration at Jebel Barakah (Glennie and Evamy 1968; Whybrow 1989; Hill et al. 2012), is an isolated lower molar of a gomphotheriid originally designated as Stegotetrabelodon grandincisivus (Madden et al. 1982). Fragments of deinothere molar loph(id)s were subsequently recovered from the formation (Whybrow et al. 1990). The majority of the remaining proboscidean specimens from the Baynunah Formation belong to a new, primitive species of elephant, previously identified as Stegotetrabelodon syrticus (Tassy 1999). Stegotetrabelodonts are particularly well documented at the sites of Ruwais, Shuwaihat, Ras Dubay'ah, Jebel Mimiyah, Umm al Ishtan, and Hamra (Stewart 2005).

Current comparative study of the Baynunah proboscidean sample benefits contextually from recent taxonomic reorganization of Afro-Arabian fossil proboscideans (Sanders et al. 2010) and materially by the addition of new specimens, including related ichnofossils (Bibi et al. 2012; Bibi et al. this volume-b). These fossils permit interpretation of social structure and behavior, and provide a better understanding of morphology and body size, particularly of the elephants. Moreover, the fossil evidence indicates that the Baynunah elephants belong in their own species and co-occurred with 


\section{PROBOSCIDEA-SANDERS}

deinotheres as well as other elephantimorph proboscideans, including a species of Tetralophodon previously unrecognized in the Baynunah Formation. Archaic morphological aspects of the elephants and presence of the tetralophodont gomphothere in the proboscidean assemblage support an 8.0-6.0 Ma age for the Baynunah Formation. Inferred biology of the proboscidean assemblage from the formation correlates with diverse habitats and feeding preferences, from browsing in closed forest conditions to grazing in open woodlands and savannas. The composition of the proboscidean assemblage does not point to any special biogeographic connection outside of the AfroArabian region.

\section{Abbreviations and Definitions}

Standard abbreviations and definitions used in the chapter are summarized from Sanders et al. (2010): Accessory central conules, enamel covered pillars at the anterior or posterior faces of loph(id)s or plates, or in the transverse valleys, partially blocking them; cm, centimeter; dental formula, expresses number of teeth at each tooth position per dental quadrant; a dental formula of 1-0-2-3/1-0-2-3 indicates that in adults, the upper dental quadrant of a species has one incisor, no canines, two premolars, and three molars, and in the lower dental quadrant has the same formula for incisors, canine, premolars, and molars; $\mathbf{d P / d p}$, upper/lower deciduous premolar; elephant, refers to any representative of the family Elephantidae; ET, enamel thickness (in mm); H, height; HI, hypsodonty index, H x 100/W; I/i, upper or lower incisor; intermediate molars, dP4/dp4, M1/m1, M2/m2; kg, kilogram; L, length; l., left; LF, lamellar frequency, number of plates or loph(id)s in 100 mm; m, meter; m. or mm., muscle, muscles; $\mathbf{M} / \mathbf{m}$, upper/lower molar, for example, $\mathrm{m} 1$ refers to a lower first molar, M3 to an upper third 


\section{PROBOSCIDEA-SANDERS}

molar; Ma, mega annum, a million years; MC, metacarpal; mm, millimeter; MT, metatarsal; plate or loph(id) formula, for example " $\mathrm{x} 7 \mathrm{x}$ " refers to a cheek tooth with seven plates or loph(id)s along with a pre- and postcingulum/cingulid; P/p, upper/lower permanent premolar; posttrite, refers to the less worn half of each loph(id), lingual in lower and buccal in upper molars; pretrite, refers to the more worn half of each loph(id), buccal in lower and lingual in upper molars; trefoil, tripartite enamel wear figure of a half-loph(id) formed by the conelets and associated anterior and posterior accessory central conules; r., right; $\mathbf{W}$, width; $\mathbf{x}$, refers to an anterior or posterior cingulum/cingulid (an upper case $\mathbf{X}$ refers to a very large cingular ridge or incipient development of a plate or loph(id)); 1, 2, $3 \ldots$. plates or loph(id)s counted from the anterior end of a molar; I, II, III ...., plates or loph(id)s counted from the posterior end of a molar that is broken anteriorly; + , broken specimen, for example $+760+$ refers to a specimen that is $760 \mathrm{~mm}$ long as preserved and is broken at both anterior and posterior ends. Detailed information on fossil localities is provided by Bibi et al. (this volume-c).

\section{SYSTEMATIC PALEONTOLOGY}

PROBOSCIDEA Illiger, 1811

DEINOTHERIOIDEA Bonaparte, 1845

DEINOTHERIIDAE Bonaparte, 1845

DEINOTHERIUM Kaup, 1829

DEINOTHERIUM SP. AFF. D. BOZASI Arambourg, 1934

Referred Specimens-AUH 21, molar fragments; AUH 159, molar fragments. 


\section{PROBOSCIDEA-SANDERS}

Diagnosis - (Based in part on Harris 1978; Sanders et al. 2010) A large-bodied species of deinothere, with teeth similar in dimensions to those of $D$. giganteum of Europe, but limited to Afro-Arabia, and larger than those of Prodeinotherium hobleyi. Compared with $D$. giganteum, rostrum downturned steeply and external nares and rostral trough narrower. Postcingular development of M2-3 is greatly reduced or absent (in contrast to P. hobleyi). Preorbital swelling reduced and situated just anterior to P3. Mandibular symphysis relatively shorter than in P. hobleyi and flexed downward strongly and more abruptly than in D. giganteum and P. hobleyi. Lower tusks curved slightly under the symphysis. Reconstruction of manus and pes suggests greater digitigrady than in $P$. hobleyi. Molars are bilophodont, except for trilophodont M1/m1 and dP4/dp4, and develop subvertical planar wear surfaces that extend transversely across the crown. No upper incisors; dental formula is $0-0-2-3 / 1-0-2-3$ for permanent teeth, which are all in function at the same time in adults (no horizontal tooth displacement). Skull low, occipital planum steeply inclined, orbit low, occipital condyles high, cranial vault pneumatized, and paroccipital processes are prominent. Reconstructed as having a trunk (external nares retracted).

\section{Description}

AUH 21 and AUH 159-These specimens, from SHU (Shuwaihat) 1, are comprised of small numbers of molar fragments that cannot be diagnosed to tooth position, though are clearly identified as belonging to a deinothere and not an elephantimorph proboscidean by remnants of transverse loph(id)s with chisel-like wear features.

Remarks - With the exception of a few sites where deinotheres are common (e.g., early Miocene Buluk and Rusinga, Kenya, middle Miocene Gebel Zelten, Libya), these 


\section{PROBOSCIDEA-SANDERS}

proboscideans are usually rare members of Afro-Arabian faunas and often are documented as fragmentary voucher specimens, as are AUH 21 and AUH 159 from SHU 1. The locality also produced remains of the elephant Stegotetrabelodon. Deinotheres appear to have inhabited closed wooded areas such as gallery forest (Harris 1978). Dental isotopic analyses show that they largely remained committed browsers throughout their existence (Cerling et al. 2005). This is important for documenting habitats proximal to the late Miocene depositional environments of the Baynunah Formation. Deinotheres were present in Afro-Arabia from at least their origins in the late

Oligocene (Sanders et al. 2004; Rasmussen and Gutíerrez 2009; Abbate et al. 2014) until their demise near the end of the early Pleistocene (Sanders et al. 2010). Although the Shuwaihat deinothere specimens do not preserve many diagnostic features, late Miocene-early Pleistocene deinotheres in Afro-Arabia have all been placed in Deinotherium bozasi (Harris 1978; Sanders et al. 2010), making it reasonable to assume that they belong in this species.

[PLACE TABLE 10.1 ABOUT HERE]

ELEPHANTIMORPHA Tassy and Shoshani, 1997 in Shoshani et al., 1998 ELEPHANTIDA Tassy and Shoshani, 1997 in Shoshani et al., 1998

GOMPHOTHERIIDAE Hay, 1922

GEN. ET SP. INDET.

Synonymy — Stegotetrabelodon grandincisivus (Madden et al., 1982); Elephantoidea indet., cf. Amebelodontidae, ?"Mastodon" grandincisivus (Tassy, 1999); Amebelodon (Hill et al., 2012); cf. Amebelodon/?"Mastodon" grandicisivus (Bibi et al., 2013). 


\section{PROBOSCIDEA-SANDERS}

Referred Specimens_-1965 I 112, partial 1. m3 (Fig. 10.1a).

\section{Description}

1965 I 112-This specimen was collected in or prior to 1965 from an unknown locality at Jebel Barakah (Glennie \& Evamy 1968) and is housed at the Bayerische Staatssammlung für Paläontologie und Geologie in Munich. It is one of the few proboscidean specimens from the Baynunah Formation that does not belong to a stegotetrabelodont. It is identifiable as an $\mathrm{m} 3$ of a gomphotheriid; it is readily distinguishable from molars of deinotheres, mammutids, and stegodonts, and also lacks features of elephant molars (such as formation of plates). By process of elimination, it belongs in Gomphotheriidae. It does not have the offset half-lophid patterns of choerolophodonts or anancine gomphotheres, and has too many lophids for a typical Gomphotherium molar. Thus, it either belongs to an amebelodont, as Tassy (1999) hinted, or is a molar of a tetralophodontine gomphothere.

Specimen 1965 I 112 has at least five lophids, though because it is broken anteriorly it is difficult to know if the front of the molar constitutes remnants of a precingulid or of another plate (Fig. 10.1a). The last lophid is composed of three conelets, and is tightly appressed to a postcingulid formed of two low conelets. Other lophids appear to have two conelets each on the pretrite and posttrite sides, which are divided by a narrow median sulcus that inhibits completion of the enamel loop until the lophid is very worn. The pretrite half-lophids and conelets are larger than those of the posttrite side. Mesoconelets on each side are of equal size to their accompanying main conelets. Wear is heaviest on the buccal, pretrite side. Enamel is massively thick and the crown is relatively narrow (Table 10.1). Cementum is mostly worn away but still 


\section{PROBOSCIDEA-SANDERS}

perceptible in the transverse valleys between lophids I and II, and blankets the postcingulid. Lophids IV and V are set oblique to the long axis of the crown, lophid III is transverse to the long axis, and lophids I and II are slightly chevronned. In occlusal view, the crown is curved, concave to the buccal side.

Remarks - For the purposes of biogeography and biochronology, it is vital to identify the proboscidean species that co-occur with stegotetrabelodonts in the Baynunah Formation. In late Miocene-earliest Pliocene eastern African sites that have produced Stegotetrabelodon orbus fossils, anancine gomphotheres and/or the primitive elephant Primelephas korotorensis usually co-occur (e.g., Kanam, Lothagam, Lukeino, and Mpesida, Kenya (MacInnes 1942; Tassy 1986, 2003; Kingston et al. 2002), Manonga, Tanzania (Sanders 1997), and Nyabusosi, Uganda (Tassy 1999)). Rarer proboscidean taxa may also coincide with S. orbus, such as stegodonts (Sanders 1999; unpublished data for Manonga, Tanzania), tetrabelodonts (Tassy 1999), and deinotheres (MacInnes 1942; Hill et al. 1985, 1986; Harris 2003). A proboscidean m3 from the late Miocene of Chorora, Ethiopia, dated to between 9-7 Ma (Katoh et al. 2016), was originally thought to be a tetralophodont proboscidean approaching the structural condition of $\mathrm{m} 3 \mathrm{~s}$ in Stegotetrabelodontinae (Coppens and Tassy in Tiercelin et al. 1979), and later was placed in Stegotetrabelodon (Geraads et al. 2002). However, the development of trefoil patterns in its pretrite half-lophids and presence of diminutive posterior accessory conules associated with posttrite half-lophids suggests a possible affinity with Tetralophodon (Sanders et al. 2010). It has a small demi-precingulid, six lophids, and a narrow postcingulid of two conelets. Distinctly divided by a median sulcus, each halflophid has two conelets. Greatest width, $86.5 \mathrm{~mm}$ at the third lophid, is relatively narrow 


\section{PROBOSCIDEA-SANDERS}

(especially in comparison with Stegotetrabelodon m3s; Table 10.1). As in specimen 1965 I 112, its anterior lophids are angled relative to the long axis of the crown, the last

two lophids are chevronned, and the last lophid is composed of three conelets. This same morphology is observable in lower molars of Tetralophodon sp. nov. from the Samburu Hills. Thus, it is possible that the $\mathrm{m} 3$ from Jebel Barakah could belong to Tetralophodon.

At Sahabi, Libya, Stegotetrabelodon syrticus co-occurs with anancine gomphotheres and with amebelodonts now recognized as belonging to the species Konobelodon cyrenaicus (Lambert 2016). This species has trilophodont m1, tetralophodont $\mathrm{m} 2$, and $\mathrm{m} 3$ with six lophids. Its lower tusks are flattened, broad, and exhibit internal dentinal tubules and rods (Gaziry 1982, 1987). Specimen 1965 I 112 resembles a right $\mathrm{m} 3$ of $K$. cyrenaicus, 200P15A, in having three conelets in the last lophid, the last two lophids chevronned, anterior lophids set oblique to the long axis of the crown, mesoconelets of equivalent size to their accompanying outer, main conelets, a narrow crown (Table 10.1), trefoil wear patterns on the pretrite side and presence of small posterior accessory conules on the posttrite side of lophids. Moreover, Konidaris et al. (2014) resolved the identity of most specimens from western Asia and eastern Europe assigned to "Mastodon" grandincisivus as Konobelodon. It is unfortunate that there have been no shovel-shaped i2s with tubules and rods recovered from the Baynunah Formation, and that specimen 1965 I 112 is broken anteriorly and worn, limiting comparison with Sahabi Konobelodon. Nonetheless, it is alternatively possible that 1965 I 112 could be an m3 of Konobelodon. If this affinity is correct, it would point to a North African biogeographic connection for the proboscidean sample from the 


\title{
PROBOSCIDEA-SANDERS
}

Baynunah Formation. Otherwise, a biogeographic link with East or Central Africa would be more likely if 1965 I 112 is an m3 of Tetralophodon.

Results of isotopic analysis of 1965 I 112 suggests that the individual was a mixed feeder (Uno \& Bibi, this volume).

[PLACE FIGURE 10.1 ABOUT HERE; WIDTH = 2 COLUMNS]

\author{
TETRALOPHODONTINAE Van der Maarel, 1932 \\ TETRALOPHODON Falconer, 1857 \\ TETRALOPHODON SP. INDET.
}

Referred Specimens-AUH 899, palate with r., 1. M2-3 (Fig. 10.1b, c).

\section{Description}

AUH 899-This specimen, from HMR (Hamra) 5, is comprised of a fragmentary remnant of a cranium, mostly comprised of a weathered palate on its ventral aspect and complete right and left M2-M3 (Fig. 10.1b). Longitudinally, M2 is angled on M3 so that the narrowest spacing between tooth rows is at the anterior end of M2, and the widest spacing across the palate is at the anterior end of M3. The M2s have four lophs and a large posterior cingulum incorporated by wear into the enamel wear figure of the last loph; the M3s have five lophs and a low, broad posterior cingulum closely appressed on the last loph (Fig. 10.1c). Few cranial details can be ascertained because of its incompleteness, except that the palate is narrow, the left malar root is low on the maxilla and arises lateral to the anterior end of M3, and the left maxilla flares slightly laterally at its anteriormost preserved extent, suggesting outward angulation of the tusks at their bases. 


\section{PROBOSCIDEA-SANDERS}

Right and left M2 are heavily worn, with each loph forming an enamel loop around excavated dentine. Combined with the wear on the anterior lophs of right and left M3, this is reminiscent of the age-grade stage XIX of Tassy (2013), out of 23 stages documented in the ontogeny of the gomphotheriine Gomphotherium angustidens. Compared with similar wear stages of modern African elephant molars, the wear on M23 in AUH 899 is equivalent to age-grade stage XIX of Laws (1966), or individuals of about 32 years of age. Thus, AUH 899 was likely to have been a mature adult, but not senescent. On the pretrite side, especially in the right M2, strong anterior accessory conules are apparently incorporated into lophs 1-4, and posterior accessory conules are incorporated into the enamel wear figures of lophs 1-2. Lophs appear to be formed of four-five conelets. Enamel is very thick (Table 10.1) and unfolded or very coarsely undulated. Only minor traces of cementum remain in the floor of the transverse valleys. Loph spacing, measured as lamellar frequency, is anteroposteriorly broad (Table 10.1). Enamel wear figures form complete enamel loops but are reminiscent in their outline of wear figures in gomphotheriid molars, with the configuration of pretrite trefoils. There is a moderately steep wear gradient between half-lophs, with the pretrite (lingual) side of the crown more heavily worn. Heavy interproximal wear at the anterior end of the M2s indicates that earlier in life M1s had been present in front of them. Smooth maxillary bone preserved on the left side shows that this molar had been horizontally displaced and its alveolus resorbed or overriden (by the M2).

The M3s of this specimen have a complex crown formed of five lophs accompanied by insignificant remnants of anterior cingulae and more substantial postcingulae that are closely appressed to the last lophs (Fig. 10.1c). On the left side, the 


\section{PROBOSCIDEA-SANDERS}

postcingulum is composed of many small conelets or apical digitations and forms a nascent sixth loph. Wear is heaviest in these molars on the lingual (pretrite) side. Cementum is only present as a trace in the floors of the transverse valleys. Each loph appears to incorporate four conelets; mesoconelets are smaller than the main, outer conelets and are nearly the same height. Anterior and posterior accessory conules are present in association with lophs 1-4 on the pretrite side, contributing to trefoil enamel outlines in the more worn half-lophs (1 and 2). On the posttrite side of the crown, a strong posterior accessory conule is associated with loph 1 and a more diminutive anterior accessory is fused to loph 3.

Remarks - Taxonomic identification of AUH 899 is not straightforward. At a casual glance, the molars resemble M1-2 of Stegotetrabelodon individual AUH 502 (Fig.10.3a, b) in having anteriormost molars with four lophs and their more posterior counterparts with five lophs. Additionally, stegotetrabelodont fossils have been recovered from Hamra. However, the molars in AUH 899 are dimensionally a better fit with M2-3 than M1-2 (Table 10.1), and there is no evidence for development of additional molars behind the posteriormost molars of this individual. Moreover, the pre- to posttrite side wear gradient is much steeper in AUH 899 than in AUH 502, suggesting that the chewing mechanism was more like that of gomphotheres, with a phase II lateral motion of the molars, than that of the horizontal fore-aft shearing of elephants (von Koenigswald 2016), which may be inferred for AUH 502. In addition, the retention of anterior and posterior accessory conules throughout the pretrite side of the posteriormost molars, and presence of accessory conules on the posttrite side, as well, are more gomphotheriid-like and reminiscent of the condition in M3 in Tetralophodon sp. nov. 


\section{PROBOSCIDEA-SANDERS}

from the late Miocene Namurungule Fm. at Samburu Hills, Kenya (KNM-SH 15858; Fig. 10.1d; Nakaya et al. 1987). Although the M3s from the Samburu Hills have six full lophs and a small posterior cingulum, there are examples of late Miocene Tetralophodon from elsewhere with only five lophs in M3 (e.g., T. longirostris from Chalkidiki, Greece; Lazaridis and Tsoukala 2014). Aside from having only five lophs in M3, AUH 899 differs from KNM-SH 15858 (Fig. 10.1c, d) in exhibiting greater wear of its anterior lophs in M3, even though both individuals have the same degree of wear in their M2s. This suggests a steeper eruption angle of M3 in Tetralophodon sp. nov. than in the Baynunah Fm. tetralophodont gomphothere, which appears more comparable to $T$. longirostris from Europe in this regard. Angulation of the basicranium of KNM-SH 15858 is reported as $60^{\circ}$ versus a much lower $32^{\circ}$ calculated for T. longirostris (Nakaya 1994).

An M3 from the late Miocene Kakara Formation in the Kisegi-Nyabusosi area of Uganda (KI 64'92), referred to a primitive form of Elephantidae by Tassy (1995), is also more reasonably assigned to Tetralophodon sp. Primitively, as in the M3 of AUH 899, it has only five lophs, anterior and posterior accessory conules associated with pretrite half-lophs 1-3 (which form trefoil enamel figures with wear) and an anterior accessory conule on posttrite half-loph 3, and only four-five conelets per loph, whereas it also displays more advanced features such as abundant cementum in the transverse valleys and mesoconelets higher than and nearly as large as the main conelets. This combination of features overlaps with what is observed in AUH 899, and is typical of the intermediate condition between gomphotheriines and elephants that occurs in Tetralophodon. Hypertrophy of mesoconelets appears to be associated with a shift in 


\section{PROBOSCIDEA-SANDERS}

masticatory pattern, from a phase II lateral chewing component to horizontal shearing. This shift is evidenced in the Kakara Formation specimen, but incompletely in AUH 899, which has modestly enlarged mesoconelets and a steeper pre- to posttrite wear gradient.

There is no doubt, then, that the affinity of AUH 899 is with Tetralophodon. These are large gomphotheriids with tetralophodont intermediate molars (at least second molars) and third molars with five or six loph(id)s (Nakaya et al. 1984, 1987; Geraads 1989; Nakaya 1993; Sanders et al. 2010). Upper and lower third and fourth permanent premolars and lower tusks are retained, contributing to an adult dental formula of 1-0-2-

3/1-0-2-3. Molar enamel is massively thick, and molar crowns are very brachyodont and large. Lamellar frequency of molars is very low. Analysis of carbon isotopes in teeth of Tetralophodon sp. nov. from Samburu Hills, Kenya indicates a preference for possibly xeric browse with a small component of $\mathrm{C}_{4}$ vegetation in their diet (Cerling et al. 1999, 2003). This dietary regimen is consistent with the Tetralophodon-like morphology of the molars of AUH 899, including their steeper pre- to posttrite molar wear patterns.

ELEPHANTIDAE Gray, 1821

STEGOTETRABELODONTINAE Aguirre, 1969

STEGOTETRABELODON Petrocchi, 1941

STEGOTETRABELODON [sp. nov.] SP. NOV.

Synonymy_Stegotetrabelodon syrticus (Tassy, 1999); Stegotetrabelodon syrticus emiratus (Khalaf, 2010) [nomen nudum].

Holotype-AUH 456, r. m3 (Fig. 10.5; Table 10.1). 


\section{PROBOSCIDEA-SANDERS}

Referred Specimens - (Based in part on Tassy 1999) AUH 234, partial M2; AUH 240, r. navicular (Fig. 10.6 g, h; AUH 271, right magnum (Fig. 10.6 c-f); AUH 342, r. p4

(Fig. 10.2 e); AUH 475, left dentary with partial $\mathrm{m} 2$ in crypt and alveoli for $\mathrm{p} 4$ and $\mathrm{m} 1$ (Fig. 10.3 a, b), and associated right dentary with alveoli for p4 and m1; AUH 479, metapodial lacking distal epiphysis; AUH 500, distal epiphysis, r. radius; AUH 501, $504,505,535,536,545,550$, thoracic vertebrae; AUH 502, partial cranium with r., 1 . M1, M2, and M3 emerging from crypt, associated with r., 1. I2 (Fig. 10.4 a-d) (probably the same individual as mandible AUH 503); AUH 503, partial mandible with r. i2 and emerging m3 (Fig. 10.4 e) (probably same individual as cranium AUH 502); AUH 506, r. juvenile femur (possibly associated with skull AUH 502 and 503); AUH 524, 1. juvenile tibia (possibly associated with skull AUH 502 and 503); AUH 528, partial r. scapula (Fig. 10.6 i); AUH 532, 538, 542, ribs (and eight additional ribs [Tassy, 1999]); AUH 534, r. juvenile tibia (possibly associated with skull AUH 502 and 503); AUH 555, C1 (atlas) vertebra; AUH 560, 1. P4 (Fig. 10.2 h); AUH 563, lumbar vertebra; AUH 1171, mandible anteriorly broken with r., 1. p4, m1, and m2 in crypt (Fig. 10.2 f, g); AUH 1737, mandible lacking dentition (Fig. 10.3 c); AUH 1738, I2 (probably antimere to AUH 1739); AUH 1739, fragmentary skeletal elements including I2 (probably antimere to AUH 1738); AUH 1740, proximal end of 1. femur, 1. tibia, r. femur (Fig. 10.6 a, b); AUH 1779, r., 1. p3-dp4 and right dentary with m1 emerging (Fig. 10.2a-d). Type locality and age — Discovered by Dr. Walid Yasin Al-Tikriti in December, 1989 at RDB (Ras Dubay'ah) 2 (Beech and Hellyer 2005). Late Miocene in age, from within the interval 8.0-6.0 Ma, based on biochronological correlation (Whybrow \& Hill, 1999; Bibi et al. 2013). 


\section{PROBOSCIDEA-SANDERS}

Distribution - Only known from the Baynunah Formation in western Abu Dhabi Emirate, United Arab Emirates.

Etymology — From the Arabic "imārah" referring to the territory of an Emir, denoting and honoring the place of occurrence (United Arab Emirates).

Diagnosis - Tall, immense elephants with two upper and two lower tusks; tusks very elongate, oval in cross-section, straight, lack enamel bands, and are remarkably gracile for their length; adult dental formula 1-0-2-3/1-0-2-3, preceded by three deciduous premolars in each dental quadrant; postcranium similar morphologically to that of modern elephants; cranium high, very broad (especially across the occipital planum), and appears anteroposteriorly compressed, with an extremely elevated basicranium; mandible with deep corpora and extremely long, downturned symphysis; permanent premolars p3, p4, and P4 recovered and P3 inferred; plate formulae of some cheek teeth differentiated from $S$. orbus, $S$. syrticus, or both $(\mathrm{dp} 4=5, \mathrm{~m} 1=5, \mathrm{~m} 3=8)$; m3 lower crowned and molars with greater expression of anterior in addition to posterior accessory conules than in other stegotetrabelodonts.

Distinguished from Primelephas korotorensis by tetrabelodonty, more elongated and downturned symphysis, greater development of anterior and posterior accessory conules (particularly in dp4 and m3), fewer lophs in P4, M1, and p4, and generally much lower crowned molars with fewer conelets per plate and more massive construction of plates. Distinguished from Loxodonta cookei by smaller permanent premolars with fewer loph(id)s, fewer plates in M1, M2, and dp4, no tendency for anteroposterior midline expansion of plates by incorporation of anterior and posterior accessory conules, much thicker enamel, much lower molar crowns, and considerably more massive 


\section{PROBOSCIDEA-SANDERS}

construction of molar plates. Differs from Mammuthus subplanifrons by much lower molar crowns with greater distribution of accessory conules, thicker enamel, more robust plate construction, no marked spiraling of I2s, much longer, downturned mandibular symphysis, and presence of lower tusks.

\section{[PLACE FIGURE 10.2 ABOUT HERE; WIDTH = 2 COLUMNS]}

\section{Description}

AUH 560-This specimen is a nicely preserved left P4 (Fig. 10.2h) from SHU (Shuwaihat) 6 that compares well with stegotetrabelodont P4s from Sahabi, Libya and Lothagam, Kenya in size (Table 10.1; Sanders 2017) and morphology. It has an anteroposteriorly narrow precingulum formed of several diminutive conelets, two lophs, and a larger postcingulum composed of a low ribbon of conelets tightly appressed to the last loph. Each half-loph of the protoloph has one robust conelet; the half-lophs of the metaloph each have two nearly equal-sized conelets. In occlusal view, the crown is nearly square. In lateral view, the protoloph is larger and higher than the metaloph and postcingulum. The lophs are pyramidal in shape and separated by a very narrow transverse valley. Only minute traces of cementum remain. AUH 560 is distinguished from P4s of Primelephas korotorensis by having fewer lophs (two versus three), and is much smaller and has fewer lophs (two versus four) than P4 in Loxodonta cookei (Sanders 2007, 2017).

AUH 342 - This small right p4 from HMR (Hamra) 1 is a particularly valuable specimen because permanent premolars are absent in modern elephants and rare in assemblages of their early predecessors (Sanders 2017). It is longer than it is wide, has 


\section{PROBOSCIDEA-SANDERS}

an ecto- and smaller entoflexus behind lophid 1, and broadens considerably at lophid 2 (Fig. 10.2 e). The remnant of the precingulid has only a single, centrally located conelet and pieces of other conelets on each side of it. As pointed out by Tassy (1999), the lophids do not form true plates. Lophid 1 is composed of two conelets; the pretrite conelet has a posteriorly oriented lobe projecting toward lophid 2. Lophid 2 has two large conelets that are each superficially subdivided into two parts, with main conelets larger than mesoconelets. Each half-lophid has a posteriorly projecting lobe. Posttrite half-lophid 2 is dumbbell shaped. Posterior to lophid 2 is a row of at least three large conelets. Because these are less massive than the conelets in lophids 1 and 2, it is reasonable to consider this row a postcingulid and not a true lophid. Consequently, the lophid formula is $\mathrm{x} 2 \mathrm{X}$. A very narrow median sulcus subdivides the crown into halves, and cementum is present in traces in the transverse valleys and median sulcus. While similar to the $\mathrm{p} 4 \mathrm{~s}$ in $\mathrm{AUH} 1171$, it shares even greater resemblance to a larger $\mathrm{p} 4$ from the Mpesida Beds, Tugen Hills, Kenya, KNM-MP 47, assigned to Stegotetrabelodon sp. (see below). Lower p4s of the contemporaneous elephant Primelephas korotorensis have more fully formed third lophids. The p4s of Gomphotherium steinheimense have weaker postcingulids, a lesser tendency to develop mesoconelets in half-lophids, and greater expression of anterior and posterior accessory conules and corresponding pretrite trefoil enamel wear patterns (see Göhlich 1998), but p4s of G. angustidens are more similar, with 2-4 conelets per lophid and stronger postcingulids, though also have stronger trefoil pattern development than in AUH 342 (see Tassy 1985). 


\section{PROBOSCIDEA-SANDERS}

AUH 1171-This mandible, from the site of HMR (Hamra) 3-1, is a superb addition both to the elephant fossil sample from the Baynunah Fm. and the gnathodental assemblage of Afro-Arabian Stegotetrabelodon. Despite an extremely friable condition, it preserves a wealth of details about mandibular corpus morphology, occlusal features of cheek teeth, and pattern of tooth emergence. The rami are rooted posterior to the cheek teeth and are largely broken away, but the corpora are nearly complete and surprisingly deep for such a young individual, particularly at the anterior end of the cheek tooth row (>140 $\mathrm{mm}$ in its support cradle). On each side, $\mathrm{p} 4$ and $\mathrm{m} 1$ are present, and the first two or three plates of $\mathrm{m} 2$ are just emerging from their crypts (Fig. 10.2 $\mathrm{f}$ ). Although extant elephants lack permanent premolars, the presence of worn m1s with emerging $\mathrm{m} 2 \mathrm{~s}$ is similar to the condition in African elephants aged 14-16 years (age group XI; Laws 1966). Anterior to the p4s, the corpora are steeply angled downward and form sharp ridges that enclose a deep trough and symphyseal region. The symphysis is broken anteriorly and the incisive alveoli are missing. From its posterior margin to anterior extent, the surviving portion of the symphysis measures $200 \mathrm{~mm}$; between the trough ridges the symphysis is narrow, with anterior and posterior widths of $35 \mathrm{~mm}$ and $60 \mathrm{~mm}$, respectively. From the anteriormost point of the symphysis to each p4, the jaw measures $310 \mathrm{~mm}$, contributing to what was certainly an extensive gap between the cheek teeth and lower tusks. The m1s are much more heavily worn than the $\mathrm{p} 4 \mathrm{~s}$, and the $\mathrm{p} 4 \mathrm{~s}$ look as if they were still rotating into position, indicating that the tooth emergence pattern in the mandible is m1-p4-m2. The m1s of AUH 1171 are the first known for elephants from the Baynunah Fm., and its $\mathrm{p} 4 \mathrm{~s}$ are more complete than an isolated p4 (AUH 342; see above) previously recovered from the formation. 


\section{PROBOSCIDEA-SANDERS}

The left $\mathrm{p} 4$ is less damaged by step fracturing than its antimere. In occlusal outline, it is squat and rounded, narrowest anteriorly, and nearly as wide as it is long (Fig. 10.2 g). It has an ecto- and smaller entoflexus between lophids 1 and 2. The lophids do not comprise true plates. There are two lophids and a pre- and postcingulid. Lophid 1 is formed of two large conelets. The pretrite conelet is more worn and extends a lobe posteriorly that touches the second pretrite half-lophid, closing off the transverse valley on the buccal side. Lophid 1 is tightly appressed to the precingulid, which is tallest medially. The posttrite side of lophid 2 is formed of two subequal-sized conelets. It is separated by a very narrow median sulcus from its pretrite half-lophid, which is dominated buccally by a large main conelet that is paired with a diminutive, bilaterally compressed mesoconelet. The main buccal-side conelet of lophid 2 also has a posteriorly projecting lobe, which contacts the central conelet of the low, narrow postcingulid. Thus, plate or lophid formula is $\mathrm{x} 2 \mathrm{x}$, and conelet composition of each lophid varies from two to four.

The p4s of AUH 1171 compare with those of Gomphotherium spp. in the same manner as Baynunah Fm. p4 AUH 342 (see above). These p4s are primitively reminiscent of p4 in gomphotheres in having only two lophids and expression of a trefoil wear pattern in pretrite half-lophid 1. In contrast, a p4 from the Lukeino Fm. in the Tugen Hills, Kenya, KNM-LU 925, attributable to Primelephas korotorensis, is more derived than the Baynunah Fm. p4s in its development of three full lophids, the presence of four conelets in each lophid, greater amount of cementum in transverse valleys, and more open transverse valleys. A p4 from the Adu-Asa Fm. of the Middle Awash, Ethiopia, STD-VP-2/86 (Saegusa and Haile-Selassie 2009), attributable to $P$. 


\section{PROBOSCIDEA-SANDERS}

korotorensis, is also more derived, with three lophids (lophid formula of $\mathrm{x} 3 \mathrm{x}$ ) and an abundant covering of cementum, though its first lophid is only comprised of two conelets. Even more derived are p4s of late Miocene-early Pliocene Loxodonta cookei from Langebaanweg, South Africa (Sanders 2007, 2017). These specimens have four full lophids and pretrite trefoils throughout the crown, and are much larger and relatively more elongate.

The p4s of AUH 1171 compare more favorably with a larger but similarly shaped p4 from the Mpesida Formation, Tugen Hills, Kenya, KNM-MP 47 (see above), and with a posterior fragment of $\mathrm{p} 4$ from the Tinde $\mathrm{Mb}$. of the Mio-Pliocene WembereManonga Fm., Tanzania, only identifiable to Elephantidae gen. et sp. indet. (Sanders 1997). Similar to the AUH 1171 p4s, KNM-MP 47 has a first lophid formed of only two conelets and is composed of two main lophids with a low, narrow precingulid and a more prominent postcingulid, yielding a lophid formula of x2X. KNM-MP 47 differs from AUH 1171 in having a posttrite as well as a pretrite accessory conule projecting posteriorly from lophid 2 (giving its half-lophids each a figure- 8 shape), three conelets in posttrite half-lophid 2, and more distinct expression of (four) conelets in the postcingulid. Unfortunately, there are no elephant p4s known from late Miocene Sahabi, Libya, for comparison.

The m1s of AUH 1171 are heavily worn but nonetheless reveal a plate formula of $\mathrm{x} 5 \mathrm{x}$ and important details of occlusal morphology (Fig. $10.2 \mathrm{~g}$ ). Occlusally, plates are worn into complete enamel loops with evidence of the presence of accessory central conules throughout the crown that extend to the posterior side of plate 5 . The wear gradient is steep antero-posteriorly, associated with the horizontal molar replacement 


\section{PROBOSCIDEA-SANDERS}

mechanism of elephants, though the entire crown is heavily abraded occlusally. Enamel is undulated or coarsely folded, and thick. Each plate is composed of a simple posttrite (lingual) side apparently formed of two conelets in a simple loop that is connected to a more complex pretrite (buccal) side formed of a large, oval central conelet and two more laterally located conelets; in each plate, the posterior central accessory conule is fused to the more central of these conelets. Thus, plates are composed of as many as five conelets. Plates are widest at their bases, and are anteroposteriorly broad, yielding a low lamellar frequency. Greatest width occurs posteriorly, which is a typical feature for $\mathrm{m} 1 \mathrm{~s}$ of elephantiform proboscideans. The precingulid is obliterated by wear and to accommodate the emerging $\mathrm{p} 4$, which the $\mathrm{m} 1$ "embraces". Cementum is present only in trace amounts in the floor of the transverse valleys. In the mandible, the molars are slightly angled away from each other posteriorly.

If the default hypothesis is correct that all elephant specimens from the Baynunah Fm. belong to the same species, the presence of five plates in $\mathrm{m} 1$ of AUH 1171 is not surprising, given the occurrence of four plates in the M1s of AUH 502. These upper and lower molars are similar in size, and in elephants lower molars often have more plates than upper molars in the same individual or within the species. Features differentiating AUH 1171 from m1 of Stegotetrabelodon syrticus from Sahabi, Libya include: the Libyan molars are tetralophodont (Gaziry 1982, 1987), exhibit strong anterior central accessory conules (in two out of three specimens), and have relatively narrower, longer crowns (Table 10.1). In S. syrticus $\mathrm{m} 1$ specimen $475 \mathrm{P} 34 \mathrm{~A}$, there is a strong posterior accessory conule behind plate 1, possible diminutive anterior and posterior accessory conules incorporated into plates 2 and 3 , and a small but well 


\section{PROBOSCIDEA-SANDERS}

defined anterior accessory conule incorporated into plate 4 (Gaziry 1982). Though no complete m1s have been recovered for $S$. orbus from East Africa, m1 specimen KNMLT 26334, from the Lower Nawata Fm. at Lothagam, Kenya, with a plate formula of $\mathrm{x} 4+$, appears as if it could have had an additional plate(s). In this $\mathrm{m} 1$, posterior central accessory conules are limited to plates 1 and 2 .

AUH 1779_-This specimen, recently recovered from the site of MIM (Jebel Mimiyah) 1, preserves a damaged right dentary, right and left p3s emerging from their crypts, very worn $\mathrm{dp} 4 \mathrm{~s}$, and a right $\mathrm{m} 1$ just emerging anteriorly from its crypt. Both right and left $\mathrm{p} 3 \mathrm{~s}$ are well preserved (Fig. $10.2 \mathrm{a}, \mathrm{b}$ ) and with only a small amount of wear on the crown, primarily observed as vertical wear facets on the main posttrite conelets of lophids 1 and 2 and the outer face of the main pretrite conelet of lophid 2 in the specimen from the left side. These teeth certainly emerged after the heavily worn dp4s (Fig. $10.2 \mathrm{c}$ ) distal to them in the mandible. They are diminutive premolars (Table 10.1), composed of modest pre- and postcingulids and three lophids, yielding a lophid formula of x3x. Occlusal shape is relatively more elongate than in $\mathrm{p} 4$, and the crown is broadest at lophid 2 . The crown is notably highest at lophid 1 . The precingulid is tallest medially, anteroposteriorly narrow, and tightly appressed to lophid 1 . The postcingulid is low, formed of three tiny conelets and a ribbon of enamel on the buccal side, and is closely appressed to lophid 3. Lophid 1 is formed of two large conelets separated by a median sulcus; the pretrite and posttrite sides of lophid 2 are more tightly squeezed together and each has two conelets; lophid 3 has a large conelet on the pretrite side separated by a 


\section{PROBOSCIDEA-SANDERS}

median sulcus from two smaller conelets on the posttrite side. In the right $\mathrm{p} 3$, traces of cementum occur in the median sulci and transverse valleys.

The left dp4 is preserved better than its antimere, missing only the buccal edge of plate 3 and parts of the lingual margins of plates 4-5. Despite the lost fragments, it can be observed that the occlusal outline is broader posteriorly, widening at plate 3 . The crown is robustly built, with thick, coarsely folded enamel and massive, low plates that are pyramidal in antero-posterior cross-section. Transverse valleys are correspondingly V-shaped. As many as six conelets contribute to each plate. Plate formula is $\mathrm{x} 5 \mathrm{X}$.

The precingulid is nearly obliterated by wear, which has formed a vertical, concave face that must have "embraced" a heavily worn dp3, prior to the emergence of p3 (Fig. 10.2 d). A gomphothere-like subdivision into pre- and posttrite half-lophids and expression of pretrite trefoil enamel wear patterns can be ascertained. Plate 1 forms a continuous enamel loop except where the anterior accessory conule contacts the anterior face of the molar. A massive posterior accessory conule has been incorporated into the enamel wear figure of plate 1 on the pretrite side. This conule abuts the prominent anterior accessory conule of plate 2 , which also forms a complete loop, with a large posterior accessory conule on its pretrite side. This, in turn, contacts the large anterior accessory conule of plate 3 , which appears to have posterior accessory conules on both its pre- and posttrite sides. In plate 4, the anterior accessory conules are also doubled; the pretrite anterior conule touches the posterior accessory conule on the pretrite side of plate 3. A small accessory conule can be observed posterior to plate 4, closely appressed to a larger anterior accessory conule of plate 5 , which in the left dp4 also sports a posterior accessory conule. Despite the presence of strong anterior and posterior 


\section{PROBOSCIDEA-SANDERS}

accessory conules throughout the crown, there is no development of loxodont " $<>$ " wear figures.

Plate 5 is composed of six conelets and is the same height as plate 4 . The crown was likely widest at plate 3 or 4 , at the lowest point on the plate. Cementum is present in the floor of the third transverse valley and coats the walls of the fourth and fifth transverse valleys. The postcingulid has five conelets, but is much lower and narrower than plate 5. A single conelet occurs posterior to this row of conelets. This morphology is most reasonably interpreted as comprising a plate formula of $\mathrm{x} 5 \mathrm{X}$ - only five true plates. Plates 1-4 have been worn, more or less, into enamel loops enclosing dentinal pools, expanded anteriorly and posteriorly by accessory conules. Although the pretrite side is a bit more worn, plate height appears fairly constant transversely across the crown, evidence of horizontal fore-aft shearing during mastication.

The dp4 is readily distinguished from that of $S$. syrticus from Sahabi, Libya, which has a plate formula of $\mathrm{x} 4 \mathrm{x}$ and accessories conules limited to the posterior side of plates 1-3 (Gaziry 1987). This tooth position is not documented with certainty for $S$. orbus. The p3 of AUH 1779 is very similar to p3 specimen KNM-LT 26339 from Lothagam, Kenya in conelet composition of lophids, lophid number (x3x), and general size (Sanders 2017), though the crown of AUH 1779 is relatively narrower and the less worn apex of the crown appears more transversely compressed. There is no p3 known for S. syrticus.

[PLACE FIGURE 10.3 ABOUT HERE; WIDTH = 2 COLUMNS] 


\section{PROBOSCIDEA-SANDERS}

AUH 475-Despite its very weathered appearance, AUH 475 retains valuable information about Baynunah Formation stegotetrabelodont gnathodental morphology. The specimen was found at Jebel Barakah in 1992, though more specific site information is lacking. It is composed of a left dentary in several pieces, with alveoli or evidence for i2, p4, and m1 (Fig. 10.3 a), along with a partial m2 in crypt (Fig. 10.3 b), and less informative right dentary fragment. Evidence for $\mathrm{p} 4$ in function with $\mathrm{m} 1$ and $\mathrm{m} 2$ still in crypt suggests that this individual was about the same age as AUH 1171 at death, or similar age-grade status as modern African elephants between the ages of 1416 years, based on development of m1-2 (but not $\mathrm{p} 4$, which is absent in modern elephants) (Laws, 1966). The dentary is $+370+\mathrm{mm}$ in length, with a corpus height of $134.2 \mathrm{~mm}$ at the posterior alveolar socket for $\mathrm{m} 1$. In lateral view, there are three mental foramina; the anteriormost foramen is large and opens anteriorly, along the side of the symphysis, the middle one is smallest and is situated at mid-corpus height anterior to the alveoli for $\mathrm{p} 4$, and the third one is elongated and opens below the alveoli to $\mathrm{p} 4$. The symphysis is broken anteriorly but is strongly downturned and medially preserves a concavity that is the remnant of the alveolus for the left i2. Sediment infilling preserves the pathway of communication between the mandibular canal and the tusk alveolus, for passage of blood vessels and nerves. On the posterior aspect of the second segment of the dentary, it is possible to observe a plate of $\mathrm{m} 2$ in crypt (Fig. $10.3 \mathrm{~b}$ ). This plate is $85.5 \mathrm{~mm}$ wide at the base, and only $42.5 \mathrm{~mm}$ high. It exhibits four conelets and the lateral sides curve strongly to the apex, which characterizes the transverse shape of archaic elephant molar plates.

[PLACE FIGURE 10.4 ABOUT HERE; WIDTH = 2 COLUMNS] 


\section{PROBOSCIDEA-SANDERS}

AUH 502-This specimen, from SHU (Shuwaihat) 6, is comprised of a partial cranium with right and left M1-2 and emerging M3, along with associated right and left upper incisors (Fig. 10.4 a-d). Tooth emergence, with M1 heavily worn, M2 worn into loops anteriorly, and M3 with well-formed plates still in crypt (Fig. 10.4a, b), most closely matches Laws' (1966) age category of XVII, or about 28 years of age. It is paired with mandible AUH 503. Given the subadult status of the individual, the length of the tusks is extraordinary. The left tusk is broken at both ends, most severely distally, where it is shattered (Fig. 10.4d). It measures $+760+\mathrm{mm}$ in length, and at its thickest aspect is 84.5 $\mathrm{mm}$ wide and $76.4 \mathrm{~mm}$ in dorsoventral height. The right tusk is nearly complete at its distal tip, but is damaged proximally and must have been longer, as the pulp cavity is missing (Fig. 10.4c). It has a length of $+1030 \mathrm{~mm}$, measures $40.5 \times 55.5 \mathrm{~mm}$ at a point $70 \mathrm{~mm}$ from the tip, and at its greatest thickness is $82.4 \mathrm{~mm}$ wide and $70.0 \mathrm{~mm}$ high. Both tusks are rounded in cross-section, lack enamel bands and longitudinal sulci, and are nearly straight. By comparison, lower tusks of probably older individuals of $S$. syrticus range in length from 1340 to $2200 \mathrm{~mm}$; the largest of these, from excavation P87A at Sahabi, Libya, has a greatest width of $147 \mathrm{~mm}$ (Gaziry 1987), and an i2 collected by Petrocchi $(1943,1954)$, with a length of $1685 \mathrm{~mm}$, has a greatest width and height of $89.8 \mathrm{~mm}$ and $72.0 \mathrm{~mm}$, respectively. These lower tusks are equivalent in length and cross-sectional area to upper tusks of the species. I2s of tusks associated with a skull excavated at Sahabi in 1934 by Petrocchi $(1943,1954)$ are $2.23 \mathrm{~m}$ in length, including their alveolar portion, and relatively very slender: width of the right incisor alveolus is only $140 \mathrm{~mm}$. The largest $\mathrm{i} 2$ on record for $S$. orbus is from the type specimen, KNM-LT 


\section{PROBOSCIDEA-SANDERS}

354 from Lothagam, measuring $1000 \mathrm{~mm}$ in length and with cross-sectional dimensions of $58 \mathrm{~mm}$ x $70 \mathrm{~mm}$. A broken i2 from Lothagam, KNM-LT 24213, with a length of $825+\mathrm{mm}$, has cross-sectional dimensions of $62.7 \mathrm{~mm} \times 78.0 \mathrm{~mm}$.

The Sahabi stegotetrabelodont cranium is incomplete and was heavily reconstructed following its recovery. Its parieto-occipital margin lacks "bossing," or bony inflation producing expansions of the margin latero-superiorly (typical of the genus Elephas, for example). The occipital planum exhibits extensive median hollowing for the nuchal ligament, and appears widest just above the ear region (Petrocchi 1943, 1954). It is massive in size, with width across the occipital of $970 \mathrm{~mm}$ and overall length (including tusks) of $>3.5 \mathrm{~m}$. The basicranium is elevated well above the level of the palate. Compared with the great size of the cranium, the condyles are diminutive; on the left side, condylar width is $130 \mathrm{~mm}$ and length is $125 \mathrm{~mm}$. Where morphology is preserved, AUH 502 appears similar to the Sahabi cranium. The basicranium is raised well above the level of the plate, the condyles appear small, and the specimen is very broad, especially low on the occipital planum and inferred for the distance across the zygomatic arches. As with the Sahabi specimen, there is considerable damage to the dorsal aspect of AUH 502. M1 has four lophs worn into complete enamel loops, and a small, low postcingulum. M2 has five lophs, a small, low postcingulum, and anteriorly is worn and shows development of both pre- and posttrite accessory conules (Fig. 10.4a).

AUH 503-This mandible, from SHU (Shuwaihat) 6, is from the same individual as cranium AUH 502. It is in poor condition, missing its rami and much of the bone of the corpora, as well as having suffered a great amount of step fracturing. Nonetheless, the 


\section{PROBOSCIDEA-SANDERS}

right i2 is well preserved and socketed in its alveolus. It is currently on display in the Environment Agency in Abu Dhabi, and could not be measured, though Tassy (1999) estimated symphyseal length as $370 \mathrm{~mm}$. Dorsoventral crushing of the mandible has considerably flattened it out, preventing assessment of symphyseal angulation relative to the corpora. Anterior molars are broken away, but $\mathrm{m} 3 \mathrm{~s}$ are apparent on both sides in their crypts. There are at least seven very low, massive pyramidal plates visible in the lateral view of the left $\mathrm{m} 3$ (Fig. 10.4e). It is possible that the left side $\mathrm{m} 3$ has been glued on backward on its dentary, as the individual plates are angled posteriorly in their current placement. The right i2 appears to lack enamel and to be oval in cross-sectional shape, with a slight outward longitudinal torque. It exhibits a slight longitudinal sulcus along its dorsal surface, a feature sometimes present in tetralophodontine i2s (Osborn 1936: fig. 320). Tassy (1999: fig. 18.4) has provided a ventral view of AUH 503 that cannot currently be seen in display. In this view, compared with the breadth of the corpora, the tusk is relatively thin.

AUH 1737-Heavily worn and poorly preserved, nonetheless AUH 1737, a nearly complete mandible recently recovered from RUW C (Ruwais Central), offers valuable details about adult lower jaws in Stegotetrabelodon [sp. nov.] sp. nov. (Fig.10.3 c). All of the specimen's dentition is missing, but size of the distal alveolus (220 mm length $\mathrm{x}$ $200 \mathrm{~mm}$ width on the left side) indicates that it housed an $\mathrm{m} 3$; there is a smaller, more proximal alveolus on each side, presumably for right and left $\mathrm{m} 2$. In modern elephants, this configuration, with $\mathrm{m} 3$ completely emerged, correlates with age group XXIII individuals of about 43 years old (Laws 1966). Length of the mandible is an impressive 


\section{PROBOSCIDEA-SANDERS}

$1500 \mathrm{~mm} ; 700 \mathrm{~mm}$ of that length includes the symphysis and incisor alveoli. On the right side, the length of the i2 alveolus is $640 \mathrm{~mm}$, and maximum width across the alveolus is $110 \mathrm{~mm}$, consistent with accommodation of a long, slender tusk that is characteristic of stegotetrabelodonts. The symphyseal/incisor alveolar portion of the jaw is about $300 \mathrm{~mm}$ at its greatest width, but is not as broad as the homologous region in amebelodonts with shovel-tusks, and in dorsal view does not have the same bilateral flare as is common in those gomphotheres. The interalveolar space is relatively narrow, only $90 \mathrm{~mm}$ wide. Length of the interalveolar space from the distal edge of the symphysis to the posterior end of $\mathrm{m} 3$ is $350 \mathrm{~mm}$. Spacing between the condyles is 360 $\mathrm{mm}$; the condyles face posteriorly and on the left side the condyle measures $140 \mathrm{~mm}$ in width.

The best stegotetrabelodont mandible for comparison with the Baynunah mandibular specimens was recovered in association with a partial cranium at Sahabi, Libya by Petrocchi in 1934, who referred to its taxon as "Tetrabelodon" while formally identifying it as Stegotetrabelodon syrticus (Petrocchi, 1943, 1954). This specimen has an extremely elongate symphysis and incisor alveolus that is strongly downturned relative to the axis of the molar alveolus, relatively short, massive corpora, and low, anteroposteriorly broad $\operatorname{rami}(\mathrm{L}=332 \mathrm{~mm}$ on the left side) with low, slender coronoid processes and wide condyles. In ventral view, the portion of the symphysis housing the incisors is transversely narrow at its proximal end and broadens towards its distal end. These morphological features are shared in common between the Sahabi mandible and Baynunah specimens. The right and left i2s have a length of $1615 \mathrm{~mm}$ and $1685 \mathrm{~mm}$, respectively, and are characteristically relatively thin for their length, with greatest 


\section{PROBOSCIDEA-SANDERS}

dimensions for the left i2 of $100 \mathrm{~mm}$ x $98 \mathrm{~mm}$ (Petrocchi 1943, 1954). With an overall length of about $3 \mathrm{~m}$, including tusks, the Sahabi mandible and the preserved portion of AUH 1737 are of similar magnitude, though the Sahabi specimen appears to be much broader across the condyles.

AUH 1738 - This specimen is an upper tusk from the site of RUW C (Ruwais Central), and is on display in the Environment Agency in Abu Dhabi. It is probably the antimere of AUH 1739 (below). Although it suffered tremendously from weathering, plastic distortion and step-fracturing, as well as having been run over by a vehicle, extensive conservation efforts have preserved the specimen for study. It is $2.54 \mathrm{~m}$ long, relatively straight, and appears very slender for its length.

AUH 1739- This isolated upper tusk is probably from a much older individual than the tusks from individual AUH 502. It is poorly preserved, suffering both plastic distortion and step-fracturing. Despite this taphonomic damage, it is possible to calculate a length of $1930 \mathrm{~mm}$, which would have been even longer had the proximal, pulp cavity portion of the specimen been preserved. This tusk and AUH 1738 overlap and exceed the range of size for I2s of S. syrticus; Petrocchi $(1943,1954)$ reported an I2 of $2230 \mathrm{~mm}$, with a relatively thin greatest diameter of $140 \mathrm{~mm}$, and a second I2 from Sahabi, Libya has a length of $1300 \mathrm{~mm}$ (Gaziry 1987). There is no sign of an enamel band, and it appears straight and relatively very narrow for its length. Widths are $90 \mathrm{~mm}$ near the proximal end, $75 \mathrm{~mm}$ near mid length, and $90 \mathrm{~mm}$ near the distal end. The distal end is blunt and rounded. 


\section{PROBOSCIDEA-SANDERS}

AUH 234-This specimen is from SHU (Shuwaihat) 4 but does not belong to the same individual as the skull from the site. It appears to be a distal fragment of an M2, with parts of the last two plates and postcingulum. Broken across the midline, the crosssection reveals that plate shape is pyramidal, and that the crown is very brachyodont (height of penultimate plate $=+52.5 \mathrm{~mm}$ ). Enamel is massively thick, 7.2-7.5 mm. Wear is planar flat across the apices of the plates. There is abundant cementum in the transverse valleys, but not covering the plate apices.

[PLACE FIGURE 10.5 ABOUT HERE; WIDTH = 1 COLUMN]

AUH 456 (type specimen)-The combination of features present in this $\mathrm{m} 3$, from RDB (Ras Dubay'ah) 2, is unique among early elephants. Roots are not preserved and the lophids have become separated from one another, though they have been re-fit tightly together and are conserved as a single, complete molar crown (Fig. 10.5). The crown has a low, anteroposteriorly narrow precingulid followed by seven lophids and a nascent eighth lophid, with a pair of small conelets posterior to it. Consequently, lophid formula can be expressed as $\mathrm{x} 8 \mathrm{x}$. Lophids are formed of three-five massive conelets; mesoconelets or central conelets are nearly as large as the outer, main conelets. There are no traces of cementum. Crown height is exceptionally brachyodont (contra Tassy 1999), and lophids have a low lamellar frequency (Table 10.1). Greatest crown width occurs at lophid 4, and the crown narrows posteriorly. Pretrite accessory conules are located posterior to lophids 1-5 (doubled and exceptionally large behind lophid 1) and anterior to lophid 2; it is difficult to observe the anterior accessory conule of lophid 1 as 


\section{PROBOSCIDEA-SANDERS}

it is broken on its pretrite side. Pre- and posttrite mesoconelets contact in the midline across a very narrow and shallow median sulcus. Lophids 1-4 are transversely straight, while lophids 5-7 are chevroned (anteriorly >-shaped); lophids are convex-convex or rectilinear in shape. Lophids 1-2 exhibit moderate apical wear, which is slightly greater on their pretrite sides. Transverse valleys are V-shaped and anteroposterior crosssectional shape of lophids is correspondingly pyramidal. Lophids are transversely broadest at their bases. Enamel is very thick (Table 10.1).

Plesiomorphic features of AUH 456 include extreme brachyodonty, thick enamel, persistence of strong accessory central conules through much of the crown, retention of pretrite trefoils in lophids 1 and 2, few robust conelets per lophid, pyramidal lophid shape, and low lamellar frequency (Table 10.1). This morphology is reminiscent of the condition of m3s in the gomphotheriid Tetralophodon (e.g., Tobien 1978; Mazo and Montoya 2003); however, AUH 456 has more lophids, lacks the offset of anterior half-lophids and posttrite accessory conules seen in some specimens of Tetralophodon, and restricts development of trefoils to the anterior end of the crown. This comparison strengthens the hypothesis that elephants evolved from tetralophodont gomphotheres via reorganization of the skull and molars in association with a shift of masticatory mechanics from lateral grinding to fore-aft shearing (Maglio 1972; von Koenigswald 2016), with African Tetralophodon from the interval 11.0-9.5 Ma serving as a good ancestral candidate (Nakaya et al. 1987; Sanders et al. 2010).

[PLACE FIGURE 10.6 ABOUT HERE; WIDTH = 2 COLUMNS] 


\section{PROBOSCIDEA-SANDERS}

AUH 240-AUH 240 is a large navicular (greatest width=154 $\mathrm{mm}$ ) from the right pes, recovered from the site of KIH (Kihal) 1. Although abraded around its margins and on the distal articular surface, it is reasonably well preserved (Fig. 10.6 g, h). Proximally, it has an oblong, concave articular surface for the astragalus which measures $132 \mathrm{~mm}$ in width and $83 \mathrm{~mm}$ in height. On its posterior aspect, it exhibits a flat articulation for the calcaneum, $58 \mathrm{~mm}$ width $\times 23 \mathrm{~mm}$ height. The abraded facets for the cuneiforms are broadest anteriorly and triangular in shape, with widths and heights of $49 \mathrm{~mm}$ x $92 \mathrm{~mm}$ (external), $58 \mathrm{~mm}$ x $101 \mathrm{~mm}$ (middle), and $48 \mathrm{~mm}$ x $105 \mathrm{~mm}$ (internal), respectively. These correspond with cuneiforms whose inferred size suggests that they supported relatively large metatarsal bases MT I-III. A small flat facet for the cuboid occupies the lateral side of AUH 240.

AUH 271-One of the few proboscidean remains from the site of JDH (Jebel Dhanna) 4 is a well-preserved magnum from a right manus (Fig. $10.6 \mathrm{c}-\mathrm{f}$ ), presumed to belong to Stegotetrabelodon [sp. nov.] sp. nov. because of the overwhelming proportion of these elephants in the proboscidean sample from the Baynunah Formation. Given its position in the center of the distal row of carpals and role in weight bearing in such a largebodied species, it is appropriately a thick, block-like bone, more robust than is typical for modern elephants. From posterior to anterior aspect it measures $128 \mathrm{~mm}$, and has greatest articular surface dimensions on its proximal aspect of $102 \mathrm{~mm}$ in width and 108 $\mathrm{mm}$ in height. Dimensions of the articular surface for MC III, the main metapodial element with which the magnum articulates, are $\mathrm{W}=63 \mathrm{~mm}$ and $\mathrm{H}=93 \mathrm{~mm}$; its articular surface for $\mathrm{MC}$ II is $\mathrm{W}=47 \mathrm{~mm}$ and $\mathrm{H}=88 \mathrm{~mm}$. Its major facet for the unciform laterally 


\section{PROBOSCIDEA-SANDERS}

is $101 \mathrm{~mm}$ wide and $102 \mathrm{~mm}$ high, and its smaller articulation for the trapezoid medially is subdivided into two small facets, measuring $35 \mathrm{~mm}$ x $38 \mathrm{~mm}$ and $49 \mathrm{~mm}$ x $44 \mathrm{~mm}$, respectively.

AUH 528-Possibly associated with the skull from SHU (Shuwaihat) 6, AUH 528 is an incomplete right scapula of impressive size (Fig. 10.6 i). From the vertebral border to the glenoid it has a length of $730 \mathrm{~mm}$, and its width is $450+\mathrm{mm}$, which must have been considerably greater as much of the scapular blade is missing caudally; elephants usually have a very projecting caudal angle of the scapular blade. The scapular spine and acromion are broken away and missing. Blade thickness increases towards the vertebral border. The glenoid is typical for elephantimorph proboscideans (mammutids, gomphotheres, stegodonts, and elephants), shallowly concave and rectangular in shape $(\mathrm{H}=175 \mathrm{~mm}, \mathrm{~W}=90 \mathrm{~mm})$. It has, however, an unusual protuberance at the caudal end of the glenoid, rather than at the cranial end as is usual in elephantimorphs. The cranial margin of the scapular blade exhibits a distinctive concavity, medial to the glenoid, which is typical for elephantimorphs and is decisive in siding the specimen.

AUH 1740 - This specimen, from the site of UAI (Um al Ishtan), is comprised of a right femur and left tibia. Both elements are well preserved (Fig. 10.6 a, b). As in modern African elephants, the femur is long and relatively slender (Smuts and Bezuidenhout 1994). It is exceptionally long, measuring $1420 \mathrm{~mm}$ from head to distal condyle, and $1340 \mathrm{~mm}$ from greater trochanter to condyle. Conservatively, that correlates with a shoulder height of approximately $370 \mathrm{~cm}$ and body mass of about 10,000-11,000 kg, 


\section{PROBOSCIDEA-SANDERS}

heavier and much taller than the average bull African elephant (for reference, this is taller than the biggest modern Asian elephant on record; record-sized African elephant bulls may be around $400 \mathrm{~cm}$ in shoulder height; the famous captive African elephant "Jumbo" had a femur of $1258 \mathrm{~mm}$ in length, shoulder height of $323 \mathrm{~cm}$, and body mass of $6150 \mathrm{~kg}$ ) (Larramendi 2016). The great stature of the Baynunah stegotetrabelodonts is consistent with having downturned tusks reaching two and one-half meters in external length.

Transversely, the femoral head is about $203 \mathrm{~mm}$ in diameter, and $320 \mathrm{~mm}$ if measured on the curve. The neck is $380 \mathrm{~mm}$ wide and short. At midshaft, the diaphysis tapers down to $157 \mathrm{~mm}$ in width and is anteroposteriorly about $95 \mathrm{~mm}$ thick, revealing substantial flattening of the shaft from front to back. Distally, the shaft is $292 \mathrm{~mm}$ wide. Typical of elephants, the medial condyle is larger than the lateral condyle, $\mathrm{W}=156 \mathrm{~mm}$ versus $128 \mathrm{~mm}$, respectively. Placing these dimensions in regression formulae established from the measurements of extant elephants (Christiansen 2004) yields heavy but wildly disparate body mass estimates, from $6875 \mathrm{~kg}$ based on midshaft width, $10,033 \mathrm{~kg}$ on length, and up to $15,612 \mathrm{~kg}$ based on width of the medial condyle.

Compared with femora of extant elephants, in the AUH 1740 femur, the head is oriented more directly proximal than proximomedial. Consequently, the neck is shorter and less defined in the fossil element. The greater trochanter is modest in size and encloses a small but deep intertrochanteric fossa. The lesser trochanter is represented as a small rugose bulge medially placed on the lower aspect of the proximal third of the shaft, well below the head. Size disparity between the medial and lateral condyles is less pronounced, and the medial epicondyle is more protuberant, than in the femora of 


\section{PROBOSCIDEA-SANDERS}

modern elephants. In posterior view, the shaft is curved concavely on the medial side and convexly on the lateral side. On the distal third of the lateral side of the shaft, an extensive, shallowly excavated, rugose surface marks the origin of $\mathrm{mm}$. soleus and the lateral head of gastrocnemius.

Tibial length, $870 \mathrm{~mm}$, is 61 percent of femoral length, similar to proportions in modern African elephants (Larramendi 2016). The tibia is also relatively slender for its length, with a transverse midshaft width of $127 \mathrm{~mm}$. Proximally, it is $260 \mathrm{~mm}$ wide, and distally it is $210 \mathrm{~mm}$ in width. The distal articular surface is concave, $150 \mathrm{~mm}$ wide, and extends farther distally on the medial side. The incisura fibularis is $50 \mathrm{~mm}$ wide. The anterior ridge is less prominent and does not run to the medial side as strongly as in extant elephants, and appears more prominent proximally for $\mathrm{m}$. tibialis cranialis than distally for $\mathrm{m}$. semitendinosus. The medial intercondylar tubercle is very prominent at the proximal articular end of the tibia. Body mass calculated from a regression formula for tibial length in proboscideans (Christiansen 2004) is $8,413 \mathrm{~kg}$. A projecting flange on the proximolateral side of the shaft is unusual and may have provided increased surface area for mm. extensor digitorum or enhanced stability for the tibiofibular articulation.

$$
\text { [PLACE FIGURE 10.7 ABOUT HERE; WIDTH = } 2 \text { COLUMNS] }
$$

Trackways - The most remarkable evidence of proboscideans in the Baynunah Formation is comprised not of skeletal remains but rather of ichnofossils that reveal striking details about social behavior, herd composition, and body size (Bibi et al. 2012). Fossil footprints are documented from multiple sites (Bibi et al., this volume-b), but those at Mleisa 1 are the most extensive, forming at least 14 different narrow-gauge 


\section{PROBOSCIDEA-SANDERS}

trackways attributed to a minimum of 13 individuals, and were probably made by the most common proboscidean in the formation, Stegotetrabelodon [sp. nov.] sp. nov. These footprint series (see Fig. 7 a) are preserved in a silty to sandy carbonate level deposited in very shallow fresh to brackish water, as indicated by analysis of ostracod fossils (Mazzini et al. 2013; Mazzini \& Kovacova, this volume), and show evidence of microbial mat growth and desiccation polygons, suggesting that the elephant tracks were made in a very short period of time, after dehydration had started but prior to complete drying out of the microbial mats. This indicates that the main grouping of trackways represents a herd traveling together (Bibi et al. 2012). The herd trackways cover a distance of $190 \mathrm{~m}$ and are largely parallel within a transverse corridor of 20-30 m. These are interpreted as being made by eight to 11 medium-to-large individuals, along with footprints of a more diminutive individual. This group can be interpreted as being similar in social structure to modern elephant herds, composed of related adult females, juveniles, and possibly an infant. Footprints of a larger, solitary and presumably male individual cross these tracks and cover a distance of $260 \mathrm{~m}$. This is the oldest definitive evidence in the proboscidean fossil record for modern-type sex-segregation of adult males and females and complex herd structure.

Body mass estimates from inferred stride lengths of individual trackways, from over $500 \mathrm{~kg}$ to nearly $5500 \mathrm{~kg}$, show that the largest individuals in the herd exceed body size of extant adult female elephants and that body size of the solitary individual falls within the range of modern adult male elephants (Bibi et al. 2012). The size of the presumed adult male is smaller than estimated from postcrania from the formation, but 


\section{PROBOSCIDEA-SANDERS}

males may leave the herd well before they reach the magnitude and status of breeding bull elephants (e.g., Moss 2001).

Elephants bear 60 percent of body weight on their forelimbs (Hutchinson et al. 2006), which explains why the round impressions of the manus are larger than the oval impressions of the pes (Robert et al. 2008; de Carvalho 2009). In elephant trackways, the hindprints may overstep the foreprints, toe marks are frequently not discernable, and the deepest part of each impression is anterior and the impression of the hindfoot may leave a slight anterior bulge (such details are critical for determining direction of travel) (Roberts et al. 2008). It is theoretically possible to calculate body mass and shoulder height for fossil elephants from footprint dimensions (Western et al. 1983; Lee and Moss 1995; Roberts et al. 2008; Schanz et al. 2013); however, in considering the estimation of height, the size of some of the footprints in the Mleisa 1 trackways exceeds that of modern elephant sampled, making it difficult to accurately predict shoulder height of fossil individuals from footprint dimensions. Nonetheless, if the scaling relationship remained the same over a larger size range than in the modern sample, the Mleisa 1 stegotetrabelodonts must have been taller than modern elephants of the same sex and age grade, with some individuals reaching $\geq 350 \mathrm{~cm}$ in shoulder height. Variation in shape of these footprints, as well as evidence for muddy sediment having been displaced upward in places around the margins of prints (Fig. 10.7 b-d), suggests that further investigation of the trackways may yield additional information about the direction of travel and the identity of fore- and hindfoot impressions.

Remarks - Stegotetrabelodonts are the most primitive and geologically oldest elephants known, comprising a monogeneric group separated in the Stegotetrabelodontinae from 


\section{PROBOSCIDEA-SANDERS}

all other elephant taxa, which are placed in the Elephantinae. Aside from the assemblage from the Baynunah Formation, stegotetrabelodont fossil remains have been recovered from late Miocene-earliest Pliocene sites in Libya (Petrocchi 1943, 1954; Gaziry 1982, 1987; Sanders 2008), Uganda (Tassy 1995), Tanzania (Sanders 1997), and Kenya (MacInnes 1942; Maglio 1970, 1973; Maglio and Ricca 1977; Hill et al. 1985, 1986; Tassy 1986, 2003; Hill 2002; Saegusa and Hlusko 2007), and a stegotetrabelodont mandible is reported from Cessaniti, in southern Italy (Ferretti et al. 2003). Thus, the group appears to be largely Afro-Arabian, and there are compelling biogeographic, chronostratigraphic, and morphological reasons to hypothesize that stegotetrabelodonts (and Elephantidae) evolved in Afro-Arabia from tetralophodont gomphotheres in the interval 9-8 Ma (Sanders et al. 2010; Sanders 2017).

In East Africa, the oldest stegotetrabelodont fossils are of Stegotetrabelodon orbus from the Lower and Upper Members of the Nawata Formation at Lothagam, Kenya, dated to the interval 7.5-5.0 Ma (Tassy 2003); the species may have persisted at the site into the Apak Member of the Nachukui Formation, 5.0-4.2 Ma (Sanders et al. 2010). It does not, however, extend to $9.5 \mathrm{Ma}$ in the Samburu Hills, contra Cerling et al. (1999). Specimens of S. orbus are of similar antiquity in the Mpesida Beds and the Lukeino Formation, Tugen Hills, Kenya, dated to about 7.0 Ma, and 6.2-5.6 Ma, respectively (Hill et al. 1985, 1986; Kingston et al. 2002). In the Western Rift, stegotetrabelodonts, also placed in $S$. orbus, are less precisely dated. Nonetheless, in the Kakara Formation and Lower and Upper Oluka Formation at Nyabusosi, Uganda they appear to be late Miocene in age (Pickford et al. 1992; Tassy 1995). In North Africa, stegotetrabelodonts have been recovered only from the site of Sahabi, Libya. They are 


\section{PROBOSCIDEA-SANDERS}

placed in a different species, $S$. syrticus, and are now estimated to derive from the interval 6.8-5.3 Ma (Warny et al. 2003; Boaz et al. 2008; El Shawaihdi et al. 2016), though de Heinzelin and El-Arnauti (1982) earlier thought that the fossiliferous vertebrate units at the site were early-middle Pliocene in age. A mandible with $\mathrm{m} 3 \mathrm{~s}$ from Cessaniti, attributed to $S$. syrticus, is from a part of Italy thought to have been part of northern Africa during the late Miocene, and is dated to the late Tortonian, approximately coeval with the Lower Member of the Nawata Formation, $>7 \mathrm{Ma}$ (Ferretti et al. 2003). The Baynunah stegotetrabelodont, at 8.0-6.0 Ma, is therefore the oldest or among the most ancient elephants known.

In all aspects of gnathodental morphology, the Baynunah Formation elephants conform to belonging in the genus Stegotetrabelodon: primitively, they possess both lower and upper tusks; have elongate, downturned mandibular symphyses; extremely brachyodont molars composed of few, well-spaced plates covered by thick enamel and comprised of a small number of large, pyramidal-shaped conelets separated by V-shaped transverse valleys; exhibit numerous accessory conules between plates; and retain upper and lower permanent third and fourth premolars. Although Tassy (1999) placed these Baynunah Formation elephants into S. syrticus, a reasonable argument can be made that they belong in their own species. The Baynunah Formation elephants have dp4s, m1s, and $\mathrm{m} 3 \mathrm{~s}$ with more plates than those of S. syrticus; their m1s lack development of anterior accessory conules; and $\mathrm{m} 3$ is lower crowned, with more massive, squat construction of plates (low, anteroposteriorly broad in lateral view), and greater development of anterior accessory conules. Perhaps these differences influenced Khalaf (2010) to propose a new subspecies, "S. syrticus emiratus" for the Baynunah Formation 


\section{PROBOSCIDEA-SANDERS}

elephants, based on geographical and unspecified morphological distinctions from Libyan S. syrticus. "Emiratus," however, is a nomen nudum in this usage because no adequate diagnosis differentiating the taxon was offered, nor was a type specimen designated. It is more properly repurposed here as a species nomen.

Integration of partial dental series from different individuals of $S$. [sp. nov.] sp. nov. shows that the species primitively retained permanent premolars (inferred P3-P4 and p3-p4) as well as the gomphothere pattern of tooth emergence/displacement, dp2dp3-dp4-p3-m1-p4-m2-m3 (see Tassy 1996). Volumetric and allometric analyses of height and body mass, based on long bone proportions and inferred from dimensions of fossilized footprints, indicate that the Baynunah Formation elephants were exceptionally tall and heavy, ranging up to or exceeding the size of the largest recorded extant African elephants. This is consistent with having elongate (ranging up to $2.5 \mathrm{~m}$ ), straight, downturned upper and lower tusks. It is difficult to envision how effectively these relatively slender tusks would have fared in interindividual combat, but there is no question that they would have been impressive in threat and mating displays. The configuration of the femoral head relative to the shaft, and close transverse spacing of footprints within trackways correlates with a narrow-gauge stance.

Analyses of dental carbon isotope composition in stegotetrabelodonts from Lothagam, Kenya show that their dietary preferences ranged from mixed feeding with a strong graze component to dedicated grazing (Cerling et al. 1999, 2003; Uno et al. 2011), and these same results were previously obtained for Baynunah Formation stegotetrabelodonts (Kingston 1999). Such a dietary regimen would be consistent with the presence of open woodland or grasslands, and these types of habitats must have been 


\section{PROBOSCIDEA-SANDERS}

locally widespread to support herds of elephants as large in body size as $S$. [sp. nov.] sp. nov. Indeed, extensive ichnofossils indicate that, similar to modern elephants, the Baynunah Formation stegotetrabelodonts were organized in herds (Bibi et al. 2012; Bibi et al., this volume-c). The range of evidence now available for $S$. [sp. nov.] sp. nov. provides the most comprehensive view of the paleobiology of all elephants known from the late Miocene.

\section{SUMMARY DISCUSSION}

The late Miocene was a time of profound change in Afro-Arabian proboscidean taxa, evidenced by the winnowing of the tremendous taxonomic diversity of the order that had been present during the early and middle Miocene. Prodeinotherium evolved into Deinotherium, but appears to have inhabited a very narrow and specialized browsing niche and few substantial morphological changes occurred (Harris 1975; Cerling et al. 1999; Sanders et al. 2010). Mammutids, choerolophodonts, amebelodonts, and gomphotheriines largely disappeared from the continent, replaced by tetralophodontines, anancine gomphotheres, stegodonts, and elephants. Except for elephants, these newcomers all may have originated in Eurasia (Sanders et al. 2010). Because the circumstances of the Afro-Arabian origin of elephants are documented at only a few sites, the localities of the Baynunah Formation provide especially valuable information for understanding the context for the emergence of elephants, as well as their early paleobiology. Body size, social structure, dental composition, morphology, and development, and dietary preferences (along with inferred habitat) of 


\section{PROBOSCIDEA-SANDERS}

stegotetrabelodont elephants are all now clearly established, in no small part because of the rich nature of the fossil evidence from the Baynunah Formation.

The dental morphology of late Miocene examples of Afro-Arabian

Tetralophodon and the Baynunah Formation stegotetrabelodonts indicates a potential ancestral-descendant relationship, consistent with their biogeography and chronostratigraphy. In fact, the boundary between advanced tetralophodontines and stegotetrabelodonts is blurred and there is no consensus concerning whether advanced tetralophodontines are actually very primitive elephants, and about where the phylogenetic limits of these taxa should be placed (e.g., Tassy 1995; Sanders et al. 2010; Saegusa et al. 2014).

Tetralophodontines from the Samburu Hills, Kenya, dated to about 9.5 Ma, have M2s with four lophs and M3s with six lophs; the late surviving tetralophodontine from the Baynunah Formation has M2 with four lophs and M3 with five lophs. This differs slightly from the condition in stegotetrabelodonts, which have pentalophodont M2s and at least six lophs in M3. Similar to stegotetrabelodonts, tetralophodontines have enlarged medial conelets, critical for formation of true plates; however, they have greater development of posttrite trefoil wear patterns and appear to have a stronger lateral wear gradient, consistent with gomphothere-like chewing patterns rather than the more even wear across plates that is the hallmark of elephant-like horizontal shearing mastication (von Koenigswald 2016). As in tetralophodontines, the basicranium of $S$. [sp. nov.] sp. nov. is very raised above the occlusal plane, but its cranium appears to be even higher and more anteroposteriorly compressed, and its mandibular symphysis is more severely downturned. These differences provide a summary of possible changes involved in the 


\section{PROBOSCIDEA-SANDERS}

evolution of the first elephants: slight increase in number of molar plates, and greater emphasis on molar plate construction and concomitant increased effectiveness of cranial muscular orientation to drive horizontal shearing of molars.

The diversity of proboscidean taxa in the Baynunah Formation is modest and not unexpected for the late Miocene of Afro-Arabia. At least three different genera are present, including a deinothere, gomphothere(s), and an elephant. Given the age of the formation, the presence of a tetralophodontine gomphothere is surprising, as is the absence of anancine gomphotheres and the primitive elephant Primelephas. The unusual composition of the proboscidean cohort in the Baynunah Formation, and the specieslevel uniqueness of its stegotetrabelodont parallels evidence for regional endemism suggested by the hippopotamines from the formation (Boisserie et al. 2017; Boisserie \& Bibi, this volume), confounding attempts to establish biogeographic links with specific regions within Africa. It also indicates that there were distinctly different habitats available for multiple contemporaneous proboscidean lineages to exploit in the Baynunah region during the late Miocene, ranging from closed canopy to open savanna and featuring a wide spectrum of dietary choices.

In summary, the Baynunah Formation in western Abu Dhabi is especially important for the study of proboscidean evolution because it provides one of the few late Miocene occurrences of these mammals in Afro-Arabia (and the only one of its age on the Arabian Peninsula), and yields a unique cohort of taxa including a new species of stegotetrabelodont elephant, at least one species of tetralophodontine gomphothere, and deinotheres. Together, these taxa indicate the effects of regional endemism in the Baynunah area. Their diverse dietary preferences are useful for better understanding the 


\section{PROBOSCIDEA-SANDERS}

types of habitats present in the region during that time. The elephants are particularly well represented in the fauna and their remains have produced valuable information about their social structure, body size, diet, and dental development. Moerover, the very primitive dental morphology of the new elephant species is consistent with a biochronological age assessment of 8.0-6.0 Ma for the Baynunah Formation, though Tetralophodon is a late survivor in this temporal interval.

Acknowledgments - The late Andrew Hill had a positive influence on the scholastic achievements and research efforts of many colleagues, including my own career, made many significant contributions to the fields of paleontology and paleoanthropology through his work on several continents, inspired us with his kindness, competence, and humor, and used his extraordinary intellectual gifts to encourage and assist others. For those reasons, and lasting friendship, I dedicate this chapter in memory and admiration of Andrew. I am grateful to Faysal Bibi, Mark Beech, and the late Andrew Hill for inviting me to participate in study of the proboscideans from the Baynunah Formation. I thank the following individuals and institutions for access to fossil specimens in their care: Meave Leakey (National Museums of Kenya and Turkana Basin Institute, Ileret, Kenya), Emma Mbua and Fredrick Manthi (National Museums of Kenya, Nairobi, Kenya), Graham and Margaret Avery (Iziko South African Museum, Cape Town, South Africa), Amandus Kweka and the late Michael Mbago (Tanzanian National Museums, Dar es Salaam, Tanzania), Ezra Musiime (Ugandan Museum, Kampala, Uganda), Muluneh Miriam (National Museum of Ethiopia, Addis Ababa, Ethiopia), Gretrud Rössner (Bayerische Staatssammlung für Paläontologie und Geologie, Munich, 


\section{PROBOSCIDEA-SANDERS}

Germany) and Mark Beech (Coastal Heritage and Palaeontology Section of the Historic Environment Department, Abu Dhabi Department of Culture and Tourism, Abu Dhabi, United Arab Emirates). Special thanks to John Klausmeyer for assistance with the figures, and to Marilyn Fox for expert preparation and conservation of the proboscidean fossils. I am appreciative for the editorial advice of Brian Kraatz and Faysal Bibi and suggestions of Juha Saarinen, Dimila Mothé, and an anonymous reviewer to improve the manuscript.

The Coastal Heritage and Palaeontology Section of the Historic Environment Department at the Abu Dhabi Department of Culture and Tourism (DCT Abu Dhabi, formerly the Tourism and Culture Authority) generously supported my research and site visits, and participation in the Baynunah Palaeontology Conference in December 2014 in Abu Dhabi, United Arab Emirates. This research was also generously supported by several Scott Turner Grants from the Department of Earth and Environmental Sciences, University of Michigan, and through grants to Terry Harrison (New York University, New York, NSF Grant BCS-0309513), Carol Ward (University of Missouri, Missouri) and Fredrick Manthi (National Museums of Kenya) (NSF Grant BCS-1231749), and by Meave Leakey and the Turkana Basin Institute. 
PROBOSCIDEA-SANDERS

\subsection{REFERENCES}

Abbate, E., Bruni, P., Ferretti, M.P., Delmer, C., Laurenzi, M.A., Hagos, M., Bedri, O., Rook, L., Sagri, M., \& Libsekal, Y. (2014). The East African Oligocene intertrappean beds: Regional distribution, depositional environments and Afro/Arabian mammal dispersals. Journal of African Earth Sciences, 99, 463-489.

Ambrose, S.J., Hlusko, L.J., Kyule, D., Deino, A., \& Williams, M. (2003).

Lemundong'o: A new 6 Ma paleontological site near Narok, Kenya Rift Valley. Journal of Human Evolution, 44, 737-742.

Barry, J.C. (1999). Late Miocene carnivore from the Emirate of Abu Dhabi, United Arab Emirates. In P.J. Whybrow \& A. Hill (Eds.), Fossil vertebrates of Arabia. With emphasis on the late Miocene faunas, geology, and palaeoenvironments of the Emirate of Abu Dhabi, United Arab Emirates (pp. 203-208). New Haven: Yale University Press.

Beech, M., \& Hellyer, P. (Eds.). (2005). Abu Dhabi-8 million years ago. Abu Dhabi, United Arab Emirates: Abu Dhabi Islands Archaeological Survey.

Bibi, F., Hill, A., Beech, M., \& Yasin, W. (2013). Late Miocene fossils from the Baynunah Formation, United Arab Emirates. In X. Wang, L.J. Flynn, \& M. Fortelius (Eds.), Fossil mammals of Asia. Neogene biostratigraphy and chronology (pp. 583594). New York: Columbia University Press.

Bibi, F., Kraatz, B., Craig, N., Beech, M., Schuster, M., \& Hill, A. (2012). Early evidence for complex social structure in Proboscidea from a late Miocene trackway site in the United Arab Emirates. Biology Letters, 8, 670-673. 


\section{PROBOSCIDEA-SANDERS}

Bibi, F., Kaya, F., Varela, S. (this volume-a). Paleoecology and Paleobiogeography of the Baynunah Fauna. In F. Bibi, B. Kraatz, M. Beech, \& A. Hill (eds.) Sands of Time: Late Miocene Fossils from the Baynunah Formation, U.A.E. (pp. xxx). Cham: Springer.

Bibi, F., Kraatz, B., Beech, M., \& Hill., A. (this volume-b). Fossil Trackways of the Baynunah Formation. In F. Bibi, B. Kraatz, M. Beech, \& A. Hill (eds.) Sands of Time: Late Miocene Fossils from the Baynunah Formation, U.A.E. (pp. xxx). Cham: Springer.

Bibi, F., Beech, M., Hill., A, \& Kraatz, B. (this volume-c). Fossil Localities of the Baynunah Formation. In F. Bibi, B. Kraatz, M. Beech, \& A. Hill (eds.) Sands of Time: Late Miocene Fossils from the Baynunah Formation, U.A.E. (pp. xxx). Cham: Springer.

Bishop, L., \& Hill, A. (1999). Fossil Suidae from the Baynunah Formation, Emirate of Abu Dhabi, United Arab Emirates. In P.J. Whybrow \& A. Hill (Eds.), Fossil vertebrates of Arabia. With emphasis on the late Miocene faunas, geology, and palaeoenvironments of the Emirate of Abu Dhabi, United Arab Emirates (pp. 254270). New Haven: Yale University Press.

Boaz, N.T., El-Arnauti, A., Agusti, J., Bernor, R.L., Pavlakis, P., \& Rook, L. (2008). Temporal, lithostratigraphic, and biochronologic setting of the Sahabi Formation, North-Central Libya. Geology of East Libya, 3, 959-972.

Boisserie, J.-R. (2005). The phylogeny and taxonomy of Hippopotamidae (Mammalia: Artiodactyla): A review based on morphology and cladistics analysis. Zoological Journal of the Linnean Society, 143, 1-26. 


\section{PROBOSCIDEA-SANDERS}

Boisserie, J.-R., Schuster, M., Beech, M.J., Hill, A., \& Bibi, F. (2017). A new species of hippopotamine (Cetartiodactyla, Hippopotamidae) from the late Miocene Baynunah Formation, Abu Dhabi, United Arab Emirates. Palaeovertebrata, 41, 1-16.

Boisserie, J.-R. \& Bibi., F. (this volume). Hippopotamidae from the Baynunah Formation. In F. Bibi, B. Kraatz, M. Beech, \& A. Hill (eds.) Sands of Time: Late Miocene Fossils from the Baynunah Formation, U.A.E. (pp. xxx). Cham: Springer.

Cerling, T.E., Harris, J.M., \& Leakey, M.G. (1999). Browsing and grazing in elephants: The isotope record of modern and fossil proboscideans. Oecologia, 120, 364-374.

Cerling, T.E., Harris, J.M., \& Leakey, M.G. (2003). Isotope paleoecology of the Nawata and Nachukui Formations at Lothagam, Turkana Basin, Kenya. In M.G. Leakey \& J.M. Harris (Eds.), Lothagam: The dawn of humanity in eastern Africa (pp. 605624). New York: Columbia University Press.

Cerling, T.E., Harris, J.M., \& Leakey, M.G. (2005). Environmentally driven dietary adaptations in African mammals. In J.R. Ehleringer, M.D. Dearing, \& T.E. Cerling (Eds.), History of atmospheric $\mathrm{CO}_{2}$ and its effects on plants, animals, and ecosystems (pp. 258-272). New York: Springer.

Cerling, T.E., Harris, J.M., MacFadden, B.J., Leakey, M.G., Quade, J., Eisenmann, V., \& Ehleringer, J.R. (1997). Pattern and significance of global ecologic change in the late Neogene. Nature, 389, 153-158.

Cerling, T.E., Wang, Y., \& Quade, J. (1993). Expansion of $\mathrm{C}_{4}$ ecosystems as an indicator of global ecological change in the late Miocene. Nature, 361, 344-345.

Christiansen, P. (2004). Body size in proboscideans, with notes on elephant metabolism. Zoological Journal of the Linnean Society, 140, 523-549. 


\section{PROBOSCIDEA-SANDERS}

de Bruijn, H. (1999). A late Miocene insectivore and rodent fauna from the Baynunah Formation, Emirate of Abu Dhabi, United Arab Emirates. In P.J. Whybrow \& A. Hill (Eds.), Fossil vertebrates of Arabia. With emphasis on the late Miocene faunas, geology, and palaeoenvironments of the Emirate of Abu Dhabi, United Arab Emirates (pp. 186-197). New Haven: Yale University Press.

de Bruijn, H., \& Whybrow, P.J. (1994). A late Miocene rodent fauna from the Baynunah Formation, Emirate of Abu Dhabi, United Arab Emirates. Proceedings Koninklijke Nederlandse Akademie van Wetenschappen, 97, 407-422.

de Carvalho, C.N. (2009). Vertebrate tracksites from the mid-late Pleistocene eolianites of Portugal: The first record of elephant tracks in Europe. Geological Quarterly, 53, 407-414.

de Heinzelin, J., \& El-Arnauti, A. (1982). Geological history of the Sahabi and related formations. Garyounis Scientific Bulletin, 1982, 5-12.

Eisenmann, V., \& Whybrow, P.J. (1999). Hipparions from the late Miocene Baynunah Formation, Emirate of Abu Dhabi, United Arab Emirates. In P.J. Whybrow \& A. Hill (Eds.), Fossil vertebrates of Arabia. With emphasis on the late Miocene faunas, geology, and palaeoenvironments of the Emirate of Abu Dhabi, United Arab

Emirates (pp. 234-253). New Haven: Yale University Press.

El-Shawaihdi, M.H., Mozley, P.S., Boaz, N.T., Salloum, F., Pavlakis, P., Muftah, A., \& Triantaphyllou, M. (2016). Stratigraphy of the Neogene Sahabi units in the Sirt Basin, northeast Libya. Journal of African Earth Sciences, 118, 87-106. 


\section{PROBOSCIDEA-SANDERS}

Ferretti, M.P., Rook, L., \& Torre, D. (2003). Stegotetrabelodon (Proboscidea, Elephantidae) from the late Miocene of southern Italy. Journal of Vertebrate Paleontology, 23, 659-666.

Gaziry, A.W. (1982). Proboscidea from the Sahabi Formation. Garyounis Scientific Bulletin, Special Issue No. 4, 101-108.

Gaziry, A.W. (1987). Remains of Proboscidea from the early Pliocene of Sahabi, Libya. In N.T. Boaz, A. El-Arnauti, A.W. Gaziry, J. de Heinzelin \& D.D. Boaz (Eds.), Neogene Paleontology and Geology of Sahabi (pp. 183-203). New York: Liss.

Gentry, A.W. (1999a). A fossil hippopotamus from the Emirate of Abu Dhabi, United Arab Emirates. In P.J. Whybrow \& A. Hill (Eds.), Fossil vertebrates of Arabia. With emphasis on the late Miocene faunas, geology, and palaeoenvironments of the Emirate of Abu Dhabi, United Arab Emirates (pp. 271-289). New Haven: Yale University Press.

Gentry, A.W. (1999b). Fossil pecorans from the Baynunah Formation, Emirate of Abu Dhabi, United Arab Emirates. In P.J. Whybrow \& A. Hill (Eds.), Fossil vertebrates of Arabia. With emphasis on the late Miocene faunas, geology, and palaeoenvironments of the Emirate of Abu Dhabi, United Arab Emirates (pp. 290316). New Haven: Yale University Press.

Geraads, D. (1989). Vertébrés fossiles du Miocène supérieur du Djebel Krechem el Artsouma (Tunisie Centrale): Comparisons biostratigraphiques. Geobios, 22, 777801. 


\section{PROBOSCIDEA-SANDERS}

Geraads, D., Alemseged, Z., \& Bellon, H. (2002). The late Miocene mammalian fauna of Chorora, Awash Basin, Ethiopia: Systematics, biochronology and the ${ }^{40} \mathrm{~K}-{ }^{40} \mathrm{Ar}$ ages of the associated volcanics. Tertiary Research, 21, 113-122.

Gilbert, C.C., Bibi, F., Hill, A., \& Beech, M.J. (2014). Early guenon from the late Miocene Baynunah Formation, Abu Dhabi, with implications for cercopithecoid biogeography and evolution. Proceedings of the National Academy of Sciences, USA, 111, 10119-10124.

Glennie, K.W., \& Evamy, B.D. (1968). Dikaka: Plants and plant-root structures associated with aeolian sand. Palaeogeography, Palaeoclimatology, Palaeoecology, $4,77-87$.

Göhlich, U.B. (1998). Elephantoidea (Proboscidea, Mammalia) aus dem Mittel- und Obermiozän der Oberen Süßwassermolasse Süddeutschlands: Odontologie und Osteologie. Münchner schaftliche Abhandlungen A, 36, 1-245.

Harris, J.M. (1978). Deinotherioidea and Barytherioidea. In V.J. Maglio \& H.B.S. Cooke (Eds.), Evolution of African Mammals (pp. 315-332). Cambridge: Harvard University Press.

Harris, J.M. (2003). Deinotheriidae from Lothagam. In M.G. Leakey \& J.M. Harris (Eds.), Lothagam: The dawn of humanity in Africa (pp. 359-361). New York: Columbia University Press.

Hill, A. (1999). Late Miocene sub-Saharan African vertebrates, and their relation to the Baynunah fauna, Emirate of Abu Dhabi, United Arab Emirates. In P.J. Whybrow \& A. Hill (Eds.), Fossil vertebrates of Arabia. With emphasis on the late Miocene 


\section{PROBOSCIDEA-SANDERS}

faunas, geology, and palaeoenvironments of the Emirate of Abu Dhabi, United Arab Emirates (pp. 420-429). New Haven: Yale University Press.

Hill, A. (2002). Paleoanthropological research in the Tugen Hills, Kenya. Journal of Human Evolution, 42, 1-10.

Hill, A., \& Gundling, T. (1999). A monkey (Primates; Cercopithecidae) from the late Miocene of Abu Dhabi, United Arab Emirates. In P.J. Whybrow \& A. Hill. (Eds.), Fossil vertebrates of Arabia. With emphasis on the late Miocene faunas, geology, and palaeoenvironments of the Emirate of Abu Dhabi, United Arab Emirates (pp. 198-202). New Haven: Yale University Press.

Hill, A., Bibi, F., Beech, M., \& Yasin, W. (2012). Before archaeology: Life and environments in the Miocene of Abu Dhabi. In D.T. Potts \& P. Hellyer (Eds.), Proceedings of the second international conference on the archaeology of the United Arab Emirates, Emirate of Abu Dhabi (pp. 22-33). Abu Dhabi: Motivate Publishing. Hill, A., Curtis, G., \& Drake, R. (1986). Sedimentary stratigraphy of the Tugen Hills, Baringo, Kenya. In L.E. Frostick, R.W. Renaut, I. Reid, and J.-J. Tiercelin (Eds.), Sedimentation in the African Rifts (pp. 285-295). Oxford: Blackwell and Geological Society of London Special Publication 25.

Hill, A., Drake, R., Tauxe, L., Monaghan, M., Barry, J.C., Behrensmeyer, A.K., Curtis, G., Jacobs, B.F., Jacobs, L., Johnson, N., \& Pilbeam, D. (1985). Neogene palaeontology and geochronology of the Baringo Basin, Kenya. Journal of Human Evolution, 14, 759-773. 


\section{PROBOSCIDEA-SANDERS}

Hutchinson, J.R., Schwerda, D., Famini, D.J., Dale, R.H.I., Fischer, M.S., \& Kram, R. (2006). The locomotor kinematics of Asian and African elephants: Changes with speed and size. The Journal of Experimental Biology, 209, 3812-3827.

Katoh, S., Beyene, Y., Itaya, T., Hyodo, H., Hyodo, M., Yagi, K., Gouzu, C., WoldeGabriel, G., Hart, W.K., Ambrose, S.H., Nakaya, H., Bernor, R.L., Boisserie, J.-R., Bibi, F., Saegusa, H., Sasaki, T., Sano, K., Asfaw, B., \& Suwa, G. (2016). New geological and palaeontological age constraint for the gorilla-human lineage split. Nature, 530, 215-218.

Khalaf-Sakerfalke von Jaffa, N.A.B.A.T. (2010) Stegotetrabelodon syrticus emiratus Khalaf, 2010: A new fossil four-tusked elephant subspecies from the Emirate of Abu Dhabi, United Arab Emirates. Gazelle: The Palestinian Biological Bulletin, 98, 1-60. Kingston, J.D. (1999). Isotopes and environments of the Baynunah Formation, Emirate of Abu Dhabi, United Arab Emirates. In P.J. Whybrow \& A. Hill (Eds.), Fossil vertebrates of Arabia. With emphasis on the late Miocene faunas, geology, and palaeoenvironments of the Emirate of Abu Dhabi, United Arab Emirates (pp. 354372). New Haven: Yale University Press.

Kingston, J.D., Jacobs, B.F., Hill, A., \& Deino, A. (2002). Stratigraphy, age and environments of the late Miocene Mpesida Beds, Tugen Hills, Kenya. Journal of Human Evolution, 42, 95-116.

Konidaris, G.E., Roussiakis, S.J., Theodorou, G.E., \& Koufos, G.D. (2014). The Eurasian occurrence of the shovel-tusker Konobelodon (Mammalia, Proboscidea) as illuminated by its presence in the late Miocene of Pikermi (Greece). Journal of Vertebrate Paleontology, 34, 1437-1453. 


\section{PROBOSCIDEA-SANDERS}

Kraatz, B., Bibi, F., \& Hill, A. (2009). New rodents from the late Miocene of the United Arab Emirates. Journal of Vertebrate Paleontology, 29, 129A.

Lambert, W.D. (2016). The phylogenetic affinities of the shovel-tusked gomphothere Konobelodon (Mammalia, Proboscidea): Is its sister group Amebelodon or Platybelodon? Journal of Vertebrate Paleontology, Program and Abstracts 2016, 171-172.

Larramendi, A. (2016). Shoulder height, body mass, and shape of proboscideans. Acta Palaeontologica Polonica, 61, 537-574.

Laws, R.M. (1966). Age criteria for the African elephant. East African Wildlife Journal, $4,1-37$.

Lazaridis, G., \& Tsoukala, E. (2014). Tetralophodon longirostris (Kaup, 1832) from late Miocene of the Kassandra peninsula (Chalkidiki, Greece). Scientific Annals, School of Geology, Aristrotle University of Thessaloniki, Greece Special Volume 102, 101.

Leakey, M.G., \& Harris, J.M. (2003). Lothagam: Its significance and contributions. In M.G. Leakey \& J.M. Harris (Eds.), Lothagam: The dawn of humanity in eastern Africa (pp. 625-660). New York: Columbia University Press.

Leakey, M.G., Feibel, C.S., Bernor, R.L., Harris, J.M., Cerling, T.E., Stewart, K.M., Storrs, G.W., Walker, A., Werdelin, L., \& Winkler, A. J. (1996). Lothagam: A record of faunal change in the late Miocene of East Africa. Journal of Vertebrate Paleontology, 16, 556-570.

Lee, P.C., \& Moss, C.J. (1995). Statural growth in known-age African elephants (Loxodonta africana). Journal of Zoology, London, 236, 29-41. 


\section{PROBOSCIDEA-SANDERS}

MacInnes, D.G. (1942). Miocene and post-Miocene Proboscidia [sic] from East Africa. Transactions of the Zoological Society, London, 25, 33-106.

Madden, C.T., Glennie, K.W., Dehm, R., Whitmore, F.C., Schmidt, R.J., Ferfoglia, R.J., \& Whybrow, P.J. (1982). Stegotetrabelodon (Proboscidea, Gomphotheriidae) from the Miocene of Abu Dhabi. Jiddah: United States Geological Survey.

Maglio, V.J. (1970). Four new species of Elephantidae from the Plio-Pleistocene of northwestern Kenya. Breviora, 341, 1-43.

Maglio, V.J. (1972). Evolution of mastication in the Elephantidae. Evolution, 26, 638658.

Maglio, V.J. (1973) Origin and evolution of the Elephantidae. Transactions of the American Philosophical Society, 63, 1-149.

Maglio, V.J., \& Ricca, A.B. (1977). Dental and skeletal morphology of the earliest elephants. Verhandelingen der Koninklijke Nederlandse Akademie van Wetenschappen, Afd. Natuurkunde Eerste Reeks, Deel 29, 1-51.

Mazo, A.V., \& Montoya, P. (2003). Proboscidea (Mammalia) from the Upper Miocene of Crevillente (Alicante, Spain). Scripta Geologica, 126, 79-109.

Mazzini, I., Bibi, F., Schuster, M., Beech, M., \& Hill, A. (2013). The "elephants" and the ostracods: A 7 My old tale from the United Arab Emirates. Il Naturalista Siciliano, 37, 209-211.

Mazzini, I. \& Kovacova, M. (this volume). Ostracods, charophytes, and pollen from the Baynunah Formation. In F. Bibi, B. Kraatz, M. Beech, \& A. Hill (eds.) Sands of Time: Late Miocene Fossils from the Baynunah Formation, U.A.E. (pp. xxx). Cham: Springer.

Moss, C.J. (2001). The demography of an African elephant (Loxodonta africana) population in Amboseli, Kenya. Journal of Zoology, London, 255, 145-156. 


\section{PROBOSCIDEA-SANDERS}

Nakaya, H. (1993). Les Faunes de Mammifères du Miocène supérieur de Samburu Hills, Kenya, Afrique de l'est et l'environnement des Pré-Hominidés. L'Anthropologie (Paris), 97, 9-16.

Nakaya, H. (1994). Faunal change of late Miocene Africa and Eurasia: Mammalian fauna from the Namurungule Formation, Samburu Hills, northern Kenya. African Study Monographs, Supplementary Issue 20, 1-112.

Nakaya, H., Pickford, M., Yasui, K., \& Nakano, Y. (1984). The late Miocene large mammal fauna from the Namurungule Formation, Samburu Hills, northern Kenya. African Study Monographs, Supplementary Issue 2, 87-131.

Nakaya, H., Pickford, M., Yasui, K., \& Nakano, Y. (1987). Additional large mammalian fauna from the Namurungule Formation, Samburu Hills, northern Kenya. African Study Monographs. Supplementary Issue 5, 79-129.

Osborn, H.F. (1936). Proboscidea. A monograph of the discovery, evolution, migration, and extinction of the mastodonts and elephants of the world. Volume I. Moeritherioidea, Deinotherioidea, Mastodontoidea. New York: American Museum Press.

Peppe, D. J., Evans, D. A. D., Beech, M., Hill, A., \& Bibi, F. (this volume). Magnetostratigraphy of the Baynunah Formation. In F. Bibi, B. Kraatz, M. Beech, \& A. Hill (eds.) Sands of Time: Late Miocene Fossils from the Baynunah Formation, U.A.E. (pp. xxx). Cham: Springer.

Petrocchi, C. (1943). Il giacimento fossilifero di Sahabi. Collezione Scientifica e Documentaria a Cura del Ministero dell' Africa Italiana, Verbania, 12, 1-169. 


\section{PROBOSCIDEA-SANDERS}

Petrocchi, C. (1954). Paleontologia di Sahabi: Parte I. Proboscidati di Sahabi. Rendiconti Accademia nazionale dei XL, 4-5, 8-74.

Pickford, M., Senut, B., \& Hadoto, D. (1993). Geology and Palaeobiology of the Albertine Rift Valley, Uganda-Zaire. Volume I: Geology. Occasional Publication 24, Orleans: Centre International pour la Formation et les Echanges Geologiques, Orleans.

Rasmussen, D.T., \& Gutíerrez, M. (2009). A mammalian fauna from the late Oligocene of northwestern Kenya. Palaeontographica, Abt. A 288, 1-52.

Roberts, D.L., Bateman, M.D., Murray-Wallace, C.V., Carr, A.S., \& Holmes, P.J. (2008). Last interglacial fossil elephant trackways dated by OSL/AAR in coastal aeolianites, Still Bay, South Africa. Palaeogeography, Palaeoclimatology, Palaeoecology, 257, 261-279.

Saegusa, H., \& Haile-Selassie, Y. (2009). Proboscidea. In Y. Haile-Selassie (Ed.), Ardipithecus kadabba. Late Miocene evidence from the Middle Awash, Ethiopia (pp. 469-516). Berkeley: University of California Press.

Saegusa, H., \& Hlusko, L.J. (2007). New late Miocene elephantoid (Mammalia: Proboscidea) fossils from Lenudong'o, Kenya. Kirtlandia, 56, 140-147.

Saegusa, H., Nakaya, H., Kunimatsu, Y., Nakatsukasa, M., Tsujikawa, H., Sawada, Y., Saneyoshi, M., \& Sakai, T. (2014). Earliest elephantid remains from the late Miocene locality, Nakali, Kenya. Scientific Annals, School of Geology Aristotle University of Thessaloniki, Greece. VI International Conference on Mammoths and Their Relatives, Grevena-Siatista, Special Volume 102, 175. 


\section{PROBOSCIDEA-SANDERS}

Sanders, W.J. (1997). Fossil Proboscidea from the Wembere-Manonga Formation, Manonga Valley, Tanzania. In T. Harrison (Ed.), Neogene Paleontology of the Manonga Valley, Tanzania (pp. 265-310). New York: Plenum Press.

Sanders, W.J. (1999). Oldest record of Stegodon (Mammalia: Proboscidea). Journal of Vertebrate Paleontology, 19, 793-797.

Sanders, W.J. (2007). Taxonomic review of fossil Proboscidea (Mammalia) from Langebaanweg, South Africa. Transactions of the Royal Society of South Africa, 62, $1-16$.

Sanders, W.J. (2008). Review of fossil Proboscidea from the late Miocene-early Pliocene site of As Sahabi, Libya. Garyounis Scientific Bulletin, 2008, 241-256.

Sanders, W.J. (2017). Horizontal tooth displacement and premolar occurrence in elephants and other elephantiform proboscideans. Historical Biology, doi.org/10.1080/80912963.2017.1297436.

Sanders, W.J., Kappelman, J., \& Rasmussen, D.T. (2004). New large-bodied mammals from the late Oligocene site of Chilga, Ethiopia. Acta Palaeontologica Polonica, 49, 365-392.

Sanders, W.J., Gheerbrant, E., Harris, J.M., Saegusa, H., \& Delmer, C. (2010). Proboscidea. In L. Werdelin \& W.J. Sanders (Eds), Cenozoic mammals of Africa (pp. 163-251). Berkeley: University of California Press.

Schanz, T., Lins, Y., Viefhaus, H., Barciaga, T., Läbe, S., Preuschoft, H., Witzel, U., \& Sander, P.M. (2013). Quantitative interpretation of tracks for determination of body mass. PloS ONE, 8(10), e77606. 


\section{PROBOSCIDEA-SANDERS}

Smuts, M.M.S., \& Bezuidenhout, A.J. (1994) Osteology of the pelvic limb of the African elephant (Loxodonta africana). Onderstepoort Journal of Veterinary Research, 61, 51-66.

Stewart, J.R. (2005). Miocene geology and fossils of Abu Dhabi. In M. Beech \& P. Hellyer (Eds.), Abu Dhabi--8 million years ago. Late Miocene fossils from the western region (pp. 17-42). Abu Dhabi, United Arab Emirates, Abu Dhabi Islands Archaeological Survey.

Tassy, P. (1985). La place des mastodontes miocènes de l'ancien monde dans la phylogénie des Proboscidea (Mammalia): Hypothèses et conjectures. Ph.D. Dissertation, Université Pierre et Marie Curie, Paris.

Tassy, P. (1986). Nouveaux Elephantoidea (Mammalia) dans le Miocène du Kenya. Paris: Cahiers de Paleontologie, Éditions du Centre de la Recherche Scientifique.

Tassy, P. (1995). Les Proboscidiens (Mammalia) Fossiles du Rift Occidental, Ouganda. In M. Pickford \& B. Senut (Eds.), Geology and palaeobiology of the Albertine Rift Valley, Uganda-Zaïre. Volume II: Palaeobiology (pp. 217-257). Orleans: CIFEG Occasional Publications, 1994/29.

Tassy, P. (1996). Growth and sexual dimorphism among Miocene elephantoids: The example of Gomphotherium angustidens. In J. Shoshani \& P. Tassy (Eds.), The Proboscidea. Evolution and palaeoecology of elephants and their relatives (pp. 92100). Oxford: Oxford University Press.

Tassy, P. (1999). Miocene elephantids (Mammalia) from the Emirate of Abu Dhabi, United Arab Emirates: Palaeobiogeographic implications. In P.J. Whybrow \& A. Hill (Eds.), Fossil vertebrates of Arabia. With emphasis on the late Miocene faunas, 


\section{PROBOSCIDEA-SANDERS}

geology, and palaeoenvironments of the Emirate of Abu Dhabi, United Arab Emirates (pp. 209-233). New Haven: Yale University Press.

Tassy, P. (2003). Elephantoidea from Lothagam. In M.G. Leakey \& J. M. Harris (Eds.), Lothagam: The dawn of humanity in eastern Africa (pp. 331-358). New York: Columbia University Press.

Tassy, P. (2013). L'anatomie cranio-mandibulaire de Gomphotherium angustidens (Cuvier, 1817) (Proboscidea, Mammalia): données issues du gisement d'En Péjouan (Miocène moyen du Gers, France). Geodiversitas, 35, 377-445.

Tiercelin, J.-J., Michaux, J., \& Bandet, Y. (1979). Le Miocène supérieur du Sud de la Dépression de l'Afar, Éthiopie: sédiments, faunes, âges isotopiques. Bulletin de la Société géologique de France, 21, 255-258.

Tobien, H. (1978). On the evolution of mastodonts (Proboscidea, Mammalia). Geologisches Jahrbuch Hessen, 106, 159-208.

Uno, K.T., Cerling, T.E., Harris, J.M., Kunimatsu, Y., Leakey, M.G., Nakatsukasa, M., \& Nakaya, H. (2011). Late Miocene to Pliocene carbon isotope record of differential diet change among East African herbivores. Proceedings of the National Academy of Science, USA, 108, 6509-6514.

Uno, K. \& Bibi, F. (this volume). Stable isotope paleoecology of the Baynunah Formation. In F. Bibi, B. Kraatz, M. Beech, \& A. Hill (eds.) Sands of Time: Late Miocene Fossils from the Baynunah Formation, U.A.E. (pp. xxx). Cham: Springer.

Vignaud, P., Duringer, P., Mackaye, H.T., Likius, A., Blondel, C., Boisserie, J.-R., de Bonis, L., Eisenmann, V., Etienne, M.-E., Geraads, D., Guy, F., Lehmann, T., Lihoreau, F., Lopez-Martinez, N., Mourer-Chauviré, C., Otero, O., Rage, J.-C., 


\section{PROBOSCIDEA-SANDERS}

Schuster, M., Viriot, L., Zazzo, A., \& Brunet, M. (2002). Geology and palaeontology of the Upper Miocene Toros-Menalla hominid locality, Chad. Nature, 418, 152-155. von Koenigswald, W. (2016). The diversity of mastication patterns in Neogene and Quaternary proboscideans. Palaeontographica, Abteilung A 307, 1-41.

Warny, S.A., Bart, P.J., \& Suc, J.-P. (2003). Timing and progression of climatic, tectonic and glacioeustatic influences on the Messinian Salinity Crisis. Palaeogeography, Palaeoclimatology, Palaeoecology, 202, 59-66.

Western, D., Moss, C., \& Georgiadis, N. (1983). Age estimation and population age structure of elephants from footprint dimensions. The Journal of Wildlife Management, 47, 1192-1197.

Whybrow, P.J. (1989). New stratotype; the Baynunah Formation (late Miocene), United Arab Emirates: Lithology and palaeontology. Newsletters on Stratigraphy, 21,1-9.

Whybrow, P.J., Hill, A., al-Tikriti, W.Y., \& Hailwood, E.A. (1990). Late Miocene primate fauna, flora and initial palaeomagnetic data from the Emirate of Abu Dhabi, United Arab Emirates. Journal of Human Evolution, 19, 583-588.

WoldeGabriel, G., Haile-Selassie, Y., Renne, P.R., Hart, W.K., Ambrose, S.J., Asfaw, B., Helken, G., \& White, T.D. (2001). Geology and palaeontology of the late Miocene Middle Awash Valley, Afar Rift, Ethiopia. Nature, 412, 175-178. 
PROBOSCIDEA - SANDERS

\section{FIGURE TITLES}

Fig. 10.1. Gnathodental remains of gomphotheres from the Baynunah Formation in comparison with molars of Tetralophodon sp. nov. from the Samburu Hills, Kenya. Abbreviations: ac, pretrite anterior accessory conule; cm, centimeter; M2, M3, upper second, third molar; pc, pretrite posterior accessory conule; poa, posttrite anterior accessory conule; pop, posttrite posterior accessory conule; $1,2,3, \ldots$, loph number counted from the anterior of the molar crown; I, II, III . . ., lophid number counted from the posterior of the molar crown; $\mathrm{x}$, anterior or posterior cingulum/cingulid. $\mathrm{c}, \mathrm{d}$ are to the same scale. (a) 1965 I 112, partial left m3 of Gomphotheriidae, gen. et sp. indet. Image courtesy of G. Rössner. (b) AUH 899, palate with right and left M2-3, Tetralophodon sp. indet. Image by F. Bibi. (c) Enlarged view, AUH 899, left M2-3. Image by F. Bibi. (d) Enlarged view, KNM-SH 15858, left M2-3, Tetralophodon sp. nov. from the Samburu Hills, Kenya.

Fig. 10.2. Premolars and associated gnathodental specimens of Stegotetrabelodon [sp. nov.] from the Baynunah Formation. Abbreviations: ac, pretrite anterior accessory conule; cm, centimeter; dp3, lower third deciduous premolar; m1, m2, lower first, second molar; $1,2,3, \ldots$, loph number counted from the anterior of the molar crown; $\mathrm{x}$, anterior or posterior cingulum/cingulid. $a, b$, e to the same scale; $c, d$ to the same scale; g, h to the same scale. (a) AUH 1779, occlusal (top) and lateral views, right p3. Anterior is to the right. Image by F. Bibi. (b) AUH 1779, occlusal and lateral views, left p3. Anterior is to the left. Image by F. Bibi. (c) AUH 1779, occlusal view, left dp4. Anterior is to the left. Image by F. Bibi. (d) AUH 1779, anterior view, left dp4. Image by F. Bibi. 


\section{PROBOSCIDEA-SANDERS}

Note extensive excavation of interproximal facet for the dp3. (e) AUH 342, occlusal (top) and lateral views, right p4. Anterior is to the right. (f) AUH 1171, mandible with right and left p4, m1, and m2 emerging from crypt. (g) AUH 1171, occlusal view, left p4-m1. Anterior is to the right. (h) AUH 560, occlusal (top) and lateral views, left P4.

Fig. 10.3. Mandibular remains of Stegotetrabelodon [sp. nov.] from the Baynunah Formation. Abbreviations: cm, centimenter; i2, lower incisor (tusk) alveolus; m.f., mental foramina; $\mathrm{m} 1, \mathrm{~m} 2, \mathrm{~m} 3$, alveoli and crypt for lower molars; $\mathrm{p} 4$, alveolus for permanent lower fourth premolar. (a) AUH 475, lateral view, left dentary, anterior to the left. (b) AUH 475, anterior view, cross-section of posterior left dentary fragment, with $\mathrm{m} 2$ plate visible in crypt. In both views, the dentary is to the same scale. (c) AUH 1737 , heavily weathered mandible. Line with arrows indicates the width of the right i2 alveolus, the most proximal end of which is medial to the mandibular canal.

Fig. 10.4. Skull remains of Stegotetrabelodon [sp. nov.] from the Baynunah Formation. Abbreviations: cm, centimeter; M1, M2, M3, upper molars; pc, pretrite posterior accessory conule; poa, posttrite anterior accessory conule; pop, posttrite posterior accessory conule; $1,2, \ldots$, plate number counted from the anterior end of the crown; $\mathrm{x}$, pre- or postcingulum. (a) Enlarged view, AUH 502, right M1-2. (b) Ventral view, AUH 502, partial cranium. The right M1 is $119 \mathrm{~mm}$ in length, for scale. (c) AUH 502, right I2, proximal end to the left. (d) AUH 502, left I2, proximal end to the left. Both tusks are to the same scale. (e) AUH 503, buccal view of the left $\mathrm{m} 3$ in crypt, from the mandible 


\section{PROBOSCIDEA-SANDERS}

associated with cranium AUH 502. Note the low, bulbous morphology of the plates in lateral view, and that seven plates are visible.

Fig. 10.5. Specimen AUH 456, right m3, Stegotetrabelodon [sp. nov.] from the Baynunah Formation. Abbreviations: ac, pretrite anterior accessory conule; cm, centimeter; pc, pretrite posterior accessory conule; $1,2, \ldots$, plate number counted from the anterior end of the crown; $\mathrm{x}$, pre- or postcingulum. Anterior is to the bottom.

Fig. 10.6. Selected postcranial elements of Stegotetrabelodon [sp. nov.] from the Baynunah Formation. Abbreviations: ast, astragalus; calc, calcaneum; cd, cuboid; cm, centimeter; gld, glenoid; ltroch, lesser trochanter; lun, lunate; mc, metacarpal; mt, metatarsal (corresponding to cuneiform bones that articulate with metatarsals); td, trapezoid; unc, unciform. a, b, i to the same scale; c-h to the same scale. (a) AUH 1740, right femur, posterior view; (b) AUH 1740, left tibia, anterior view; (c) AUH 271, right magnum, proximal view (anterior is to the bottom in c-f); (d) AUH 271, right magnum, lateral view; (e) AUH 271, right magnum, medial view; (f) AUH 271, right magnum, distal view; (g) AUH 240, right navicular, proximal view (anterior is to the bottom in $\mathrm{g}$, h); (h) AUH 240, right navicular, distal view; (i) AUH 528, right scapula, outer (lateral) view.

Fig. 10.7. Proboscidean footprints and trackway at the site of Mleisa 1, attributed to Stegotetrabelodon [sp. nov.]. (a) Elephant footprint series, part of the herd grouping of trackways. There are 14 proboscidean trackways at the site, from a minimum of 13 


\section{PROBOSCIDEA-SANDERS}

individuals. (b-d) Shape variation in footprint impressions. The compass used for scale is $7.5 \mathrm{~cm}$ in length. (b) Note the displacement of sediment on both sides of the impression(s). (c) Note that the impression is deeper to the left and sediment is displaced more prominently at that side of the print, indicating direction of movement may have been to the left. (d) Impression shape is oval, possibly indicating a hindfoot print. The impression is deeper to the left and sediment is displaced more prominently at that side of the print, suggesting direction of movement was to the left.

[TYPESETTER: TABLE 10.1 PROVIDED AS SEPARATE DOC FILE, TO BE INSERTED IN LANDSCAPE FORMAT] 
Table 10.1. Comparative dimensions, indices, and composition of Baynunah Formation and other late Miocene proboscidean cheek teeth. All linear dimensions are in mm. Baynunah Formation specimens are in bold type. Abbreviations: ac, pretrite anterior accessory conule; dp, lower deciduous premolar; e., estimated; ET, enamel thickness; H, height; HI, hypsodonty index, H x 100/W; L, length; LF, lamellar frequency, number of plate/loph(id)s per 100 mm; M/m, upper or lower molar; P/p, upper or lower permanent premolar; pc, pretrite posterior accessory conule; PF, plate formula; poa, posttrite anterior accessory conule; pop, posttrite posterior accessory conule; W, width; WI, width index, W x 100/L; x, pre- or postcingulum(cingulid); X, large pre- or postcingulum(cingulid) that forms an incipient plate or loph(id); $\mathbf{1}, \mathbf{2}, \mathbf{3}, \ldots$, plate or loph(id) counted from the anterior end of the crown; (1), (2), (3), .., indicates plate or loph(id) of greatest crown width; I, II, III, . . , plate or loph(id) counted from the posterior end of the crown; +, indicates missing part of tooth and that the original dimension was greater.

\begin{tabular}{|c|c|c|c|c|c|c|c|c|c|c|c|}
\hline $\begin{array}{l}\text { Site/Taxon/Accession } \\
\text { Number }\end{array}$ & Tooth & $\mathbf{P F}$ & $\mathbf{L}$ & $\mathbf{W}$ & $\mathbf{H}$ & ET & HI & $\mathbf{L F}$ & WI & $\begin{array}{l}\text { Accessory } \\
\text { Conules }\end{array}$ & $\begin{array}{l}\text { Apical } \\
\text { Digitations }\end{array}$ \\
\hline $\begin{array}{l}\text { Shuwaihat, Abu Dahbi, } \\
\text { Baynunah Fm., }\end{array}$ & l. P4 & $\mathbf{x 2 x}$ & $\begin{array}{l}49.7 \\
\left(49.7^{k}\right)\end{array}$ & $\begin{array}{l}48.5(1) \\
\left(47.6^{k}\right)\end{array}$ & $\begin{array}{l}32.5 \\
\left(28.2^{k}\right)\end{array}$ & $\begin{array}{l}- \\
--\end{array}$ & $\begin{array}{l}67 \\
\left(59^{k}\right)\end{array}$ & $\begin{array}{l}-- \\
--\end{array}$ & $\begin{array}{l}98 \\
\left(96^{k}\right)\end{array}$ & $\begin{array}{l}- \\
--\end{array}$ & $\begin{array}{l}2-4 \\
--\end{array}$ \\
\hline $\begin{array}{l}\text { Stegotetrabelodon [sp. } \\
\text { nov], sp. nov., AUH } 560\end{array}$ & & & & & & & & & & & \\
\hline $\begin{array}{l}\text { Sahabi, Libya, } \\
\text { Stegotetrabelodon }\end{array}$ & 1. P4 & $x 2 x$ & 54.0 & $44.0(1)$ & -- & -- & -- & -- & 81 & -- & $2-4$ \\
\hline
\end{tabular}




\begin{tabular}{|c|c|c|c|c|c|c|c|c|c|c|c|}
\hline Sahabi, Libya, S. syrticus, & 1. P4 & $\mathrm{x} 2 \mathrm{x}$ & e. 46.0 & e. 41.0 & -- & -- & -- & -- & 89 & -- & -- \\
\hline $18 \mathrm{P} 21 \mathrm{~A}^{\mathrm{f}}$ & & & & (1) & & & & & & & \\
\hline Sahabi, Libya, S. syrticus, & 1. P4 & $x 2 x$ & e. 45.0 & e. 41.0 & -- & -- & -- & -- & 91 & -- & -- \\
\hline $421 \mathrm{P} 34 \mathrm{~A}^{\mathrm{f}}$ & & & & (1) & & & & & & & \\
\hline Lothagam, Kenya, Lower & r. P4 & $\mathrm{x} 2 \mathrm{X}$ & 50.4 & $52.0(2)$ & worn & 3.6 & -- & -- & 103 & -- & $2-4$ \\
\hline \multicolumn{12}{|l|}{ Nawata Fm., S. orbus, } \\
\hline \multicolumn{12}{|l|}{ KNM-LT 343} \\
\hline Tugen Hills, Kenya, & 1. P4 & $\mathrm{x} 3+$ & $47.4+$ & $40.9+$ & 25.0 & -- & -- & -- & -- & -- & 4 \\
\hline \multicolumn{12}{|l|}{ Lukeino Fm., } \\
\hline \multicolumn{12}{|l|}{ Primelephas } \\
\hline \multicolumn{12}{|l|}{ korotorensis, KNM-LU } \\
\hline \multicolumn{12}{|l|}{730} \\
\hline Lothagam, Kenya, Lower & 1. P4 & $+2 \mathrm{x}$ & +43.0 & 52.1 & $22.0+$ & 2.6 & $42.7+$ & -- & -- & -- & -- \\
\hline \multicolumn{12}{|l|}{ Nawata Fm., $P$. } \\
\hline \multicolumn{12}{|l|}{ korotorensis, KNM-LT } \\
\hline $23782^{\mathrm{n}}$ & & & & & & & & & & & \\
\hline
\end{tabular}




\begin{tabular}{|c|c|c|c|c|c|c|c|c|c|c|c|}
\hline $\begin{array}{l}\text { Kisegi-Nyabusosi Area, } \\
\text { Uganda, Lower Oluka }\end{array}$ & r. P4 & $\mathrm{x} 3 \mathrm{x}$ & $\begin{array}{l}\text { e. } 53.1 \\
(52.0)^{\mathrm{i}}\end{array}$ & $\begin{array}{l}51.9 \\
(46.8)^{\mathrm{i}}\end{array}$ & -- & $3.4-4.8$ & -- & -- & $\begin{array}{l}98 \\
(90)^{\mathrm{i}}\end{array}$ & -- & $2-5$ \\
\hline \multicolumn{12}{|l|}{ Fm., P. korotorensis, NY } \\
\hline \multicolumn{12}{|l|}{$46^{\prime} 92$} \\
\hline & 1. P4 & $x 3 x$ & $\begin{array}{l}54.4 \\
(57.3)^{\mathrm{i}}\end{array}$ & $\begin{array}{l}45.9 \\
(45.9)^{\mathrm{i}}\end{array}$ & -- & $3.4-4.8$ & -- & -- & $\begin{array}{l}84 \\
(80)^{\mathrm{i}}\end{array}$ & -- & $2-5$ \\
\hline Langebaanweg, South & r. P4 & $\mathrm{x} 4$ & 69.3 & $52.0(1)$ & worn & $2.6-3.0$ & -- & -- & 75 & ac1; pc1-3 & worn \\
\hline \multicolumn{12}{|l|}{ Africa, Pelletal Phosphate } \\
\hline \multicolumn{12}{|l|}{ Mb., Varswater Fm., } \\
\hline \multicolumn{12}{|l|}{ Loxodonta cookei, PQ-L } \\
\hline \multicolumn{12}{|l|}{$45616^{\circ}$} \\
\hline Shuwaihat, Abu Dhabi, & r. M1 & $4 x$ & $119.0^{\mathrm{k}}$ & $73.6(3)^{k}$ & worn & 4.0 & -- & $3.9^{\mathrm{k}}$ & 62 & -- & -- \\
\hline \multicolumn{12}{|l|}{ Baynunah Fm., } \\
\hline \multicolumn{12}{|l|}{ Stegotetrabelodon [sp. } \\
\hline novl, sp. nov., AUH 502 & & & & & & & & & & & \\
\hline & l. M1 & $4 x$ & $116.7^{\mathrm{k}}$ & $72.1(4)^{k}$ & worn & -- & -- & $3.8^{\mathrm{k}}$ & 62 & -- & -- \\
\hline
\end{tabular}




\begin{tabular}{|c|c|c|c|c|c|c|c|c|c|c|c|}
\hline Samburu Hills, Kenya, & r. M1 & 4 & 147.3 & 83.8 & $50.0+$ & -- & -- & 2.7 & 57 & -- & -- \\
\hline \multicolumn{12}{|l|}{ Namurungule Fm., } \\
\hline \multicolumn{12}{|l|}{ Tetralophodon sp., } \\
\hline \multicolumn{12}{|l|}{ KNM-SH $12307^{\mathrm{e}}$} \\
\hline & 1. M1 & 4 & 148.4 & 81.1 & $58.0+$ & -- & -- & 2.7 & 55 & -- & -- \\
\hline Sahabi, Libya, & 1. M1? & $x 4 x$ & 158.0 & $87.0(3)$ & $49.0(4)$ & -- & 56 & -- & 55 & pc1-2 & -- \\
\hline Stegotetrabelodon & $\left(1 . M 2^{f}\right)$ & $\left(x 5^{f}\right)$ & & & & & & & & & \\
\hline \multicolumn{12}{|l|}{ syrticus, $7 \mathrm{P} 16 \mathrm{~A}^{\mathrm{f}}$} \\
\hline Lothagam, Kenya, Lower & 1. M1 & $\mathrm{x} 3+$ & $75.3+$ & 67.6 & $52.8+$ & $3.0-3.2$ & -- & -- & -- & at least pc1- & $5-6$ \\
\hline Nawata Fm., & & & & & & & & & & 3 & \\
\hline \multicolumn{12}{|l|}{ Stegotetrabelodon orbus, } \\
\hline KNM-LT 23795B & & & & & & & & & & & \\
\hline
\end{tabular}




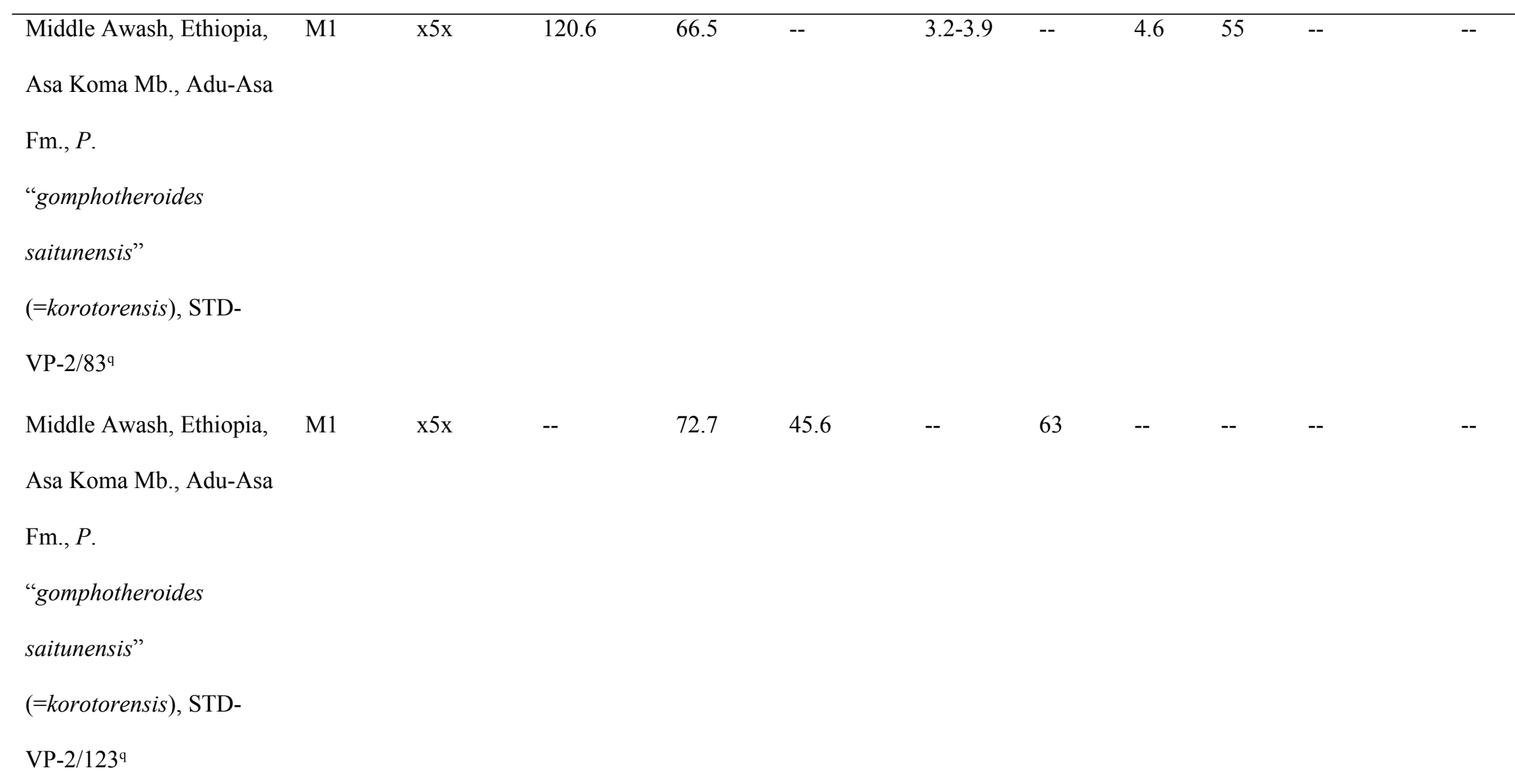




\begin{tabular}{|c|c|c|c|c|c|c|c|c|c|c|c|}
\hline & & & & & & & & & & & \\
\hline Middle Awash, Ethiopia, & M1 & $x 5 \mathrm{x}$ & 110.2 & 71.8 & 38.6 & $2.8-3.3$ & 54 & 4.9 & 65 & pc1 (may be & $5-8$ \\
\hline Asa Koma Mb., Adu-Asa & & & & & & & & & & small & \\
\hline Fm., $P$. & & & & & & & & & & posterior & \\
\hline "gomphotheroides & & & & & & & & & & conules & \\
\hline saitunensis" & & & & & & & & & & associated & \\
\hline (=korotorensis), STD- & & & & & & & & & & with plates 2 & \\
\hline $\mathrm{VP}-2 / 898^{\mathrm{q}}$ & & & & & & & & & & and 3) & \\
\hline Kisegi-Nyabusosi Area, & r. M1 & $x 5 x$ & 125.1 & 74.1 & -- & -- & -- & 4.0 & 59 & $\mathrm{pc} 1$ & $5-7$ \\
\hline Uganda, Lower Oluka & & & & & & & & & & & \\
\hline Fm., P. korotorensis, NY & & & & & & & & & & & \\
\hline $46^{\prime} 92$ & & & & & & & & & & & \\
\hline & 1. M1 & $x 5 x$ & 126.8 & 73.0 & -- & -- & -- & 4.5 & 58 & $\mathrm{pc} 1,2$ & $5-7$ \\
\hline Langebaanweg, South & 1. M1 & $5 \mathrm{x}$ or 6 & 141.8 & $77.7(2)$ & worn & $2.6-3.0$ & -- & 4.0 & 55 & ac1-5; pc1-4 & 5 \\
\hline Africa, Pelletal Phosphate & & & & & & & & & & & \\
\hline Mb., Varswater Fm., & & & & & & & & & & & \\
\hline Loxodonta cookei, PQ-L & & & & & & & & & & & \\
\hline $45617^{\circ}$ & & & & & & & & & & & \\
\hline
\end{tabular}


Langebaanweg, South

r. M1

$\mathrm{x} 6$

Africa, Pelletal Phosphate

Mb., Varswater Fm., $L$.

cookei, PQ-L $45616^{\circ}$

Tugen Hills, Kenya

\begin{tabular}{|c|c|}
\hline 1. M1 & $+6 x$ \\
\hline
\end{tabular}

66.8 (3) worn

$3.0-3.5=-$

$4.3 \quad--\quad$ pc1-5, ac1-6 5

Chemeron Fm., L. cookei,

KNM-BC 1761

\section{Hamra, Abu Dhabi,}

r. M2

$\mathrm{x} 4 \mathrm{X}$

e. 95.0

(3)

Baynunah Fm., cf.

Tetralophodon sp. indet.,

AUH 899

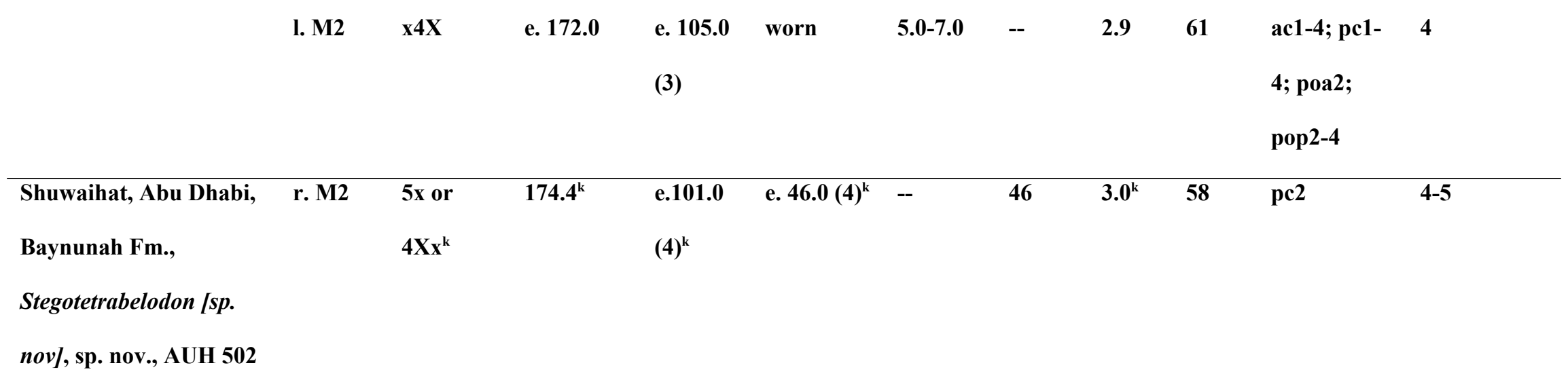




\begin{tabular}{|c|c|c|c|c|c|c|c|c|c|c|c|}
\hline & 1. M2 & $\begin{array}{r}5 x \text { or } \\
4 X x^{k}\end{array}$ & $176.9^{k}$ & $\begin{array}{l}101.4 \\
(4)^{k}\end{array}$ & $50.2(4)^{k}$ & -- & 50 & $2.9^{k}$ & 57 & pc2 & 4 \\
\hline \multirow{6}{*}{$\begin{array}{l}\text { Samburu Hills, Kenya, } \\
\text { Lower Mb., } \\
\text { Namurungule Fm., } \\
\text { Tetralophodon sp., } \\
\text { KNM-SH } 15858\end{array}$} & r. M2 & $\mathrm{x} 4 \mathrm{X}$ & $190.0^{\mathrm{g}}$ & 101.0 & worn & -- & -- & -- & 53 & ac1-3; pc1- & 4 \\
\hline & & & & $(3)^{\mathrm{g}}$ & & & & & & 3; poa2; & \\
\hline & & & & & & & & & & pop2-4 & \\
\hline & & & & & & & & & & & \\
\hline & 1. M2 & $x 4 X$ & $166.0^{\mathrm{g}}$ & 100.0 & worn & -- & -- & -- & 60 & ac1-3; pc1- & 4 \\
\hline & & & & $(3)^{\mathrm{g}}$ & & & & & & $3 ;$ poa2; & \\
\hline syrticus, $1 \mathrm{P} \mathrm{A}^{\mathrm{f}}$ & & & & & & & & & & & \\
\hline Lothagam, Kenya,? & r. M2 & $+5 \mathrm{x}$ & +160.5 & $92.6(4)$ & worn & $5.5-7.0$ & -- & 3.25 & -- & pc1-4 & 5 \\
\hline Apak/Upper Nawata Fn & & & & & & & & & & & \\
\hline Stegotetrabelodon orbu & & & & & & & & & & & \\
\hline (type), KNM-LT 354 & & & & & & & & & & & \\
\hline
\end{tabular}




\begin{tabular}{|c|c|c|c|c|c|c|c|c|c|c|c|}
\hline \multirow{2}{*}{$\begin{array}{l}\text { Lothagam, Kenya, Lower } \\
\text { Nawata Fm., Primelephas }\end{array}$} & r. M2 & $\mathrm{x} 5 \mathrm{X}$ & 171.8 & $83.3(3)$ & $63.0(4)$ & unworn & 76 & 4.0 & 48 & pc1-4 & as many as 6 \\
\hline & & & & & & & & & & & apical \\
\hline korotorensis, KNM-LT & & & & & & & & & & & digitations \\
\hline \multicolumn{12}{|l|}{358} \\
\hline & 1. M2 & $x 5 x$ & 168.9 & $85.8(4)$ & $61.5(4)$ & unworn & 72 & 4.0 & 51 & pc1-4 & as many as 7 \\
\hline & & & & & & & & & & & apical \\
\hline & & & & & & & & & & & digitations \\
\hline Tugen Hills, Kenya, & r. M2 & $x 5 x$ & 169.2 & 86.7 & 57.0 & 4.7 & 66 & 3.5 & 51 & pc1 & $6-8$ \\
\hline Lukeino Fm., $P$. & & & & & & & & & & (doubled), 2 & \\
\hline \multicolumn{12}{|l|}{ korotorensis, KNM-LU } \\
\hline \multicolumn{12}{|l|}{718} \\
\hline Middle Awash, Ethiopia, & M2 & $\mathrm{x} 6$ & $149.8^{q}$ & $80.5^{\mathrm{q}}$ & $53.0^{\mathrm{q}}$ & $4.0-4.4^{\mathrm{q}}$ & $66^{\mathrm{q}}$ & $4.2^{\mathrm{q}}$ & $54^{\mathrm{q}}$ & pc1 & $5-7$ \\
\hline Kuseralee Mb., Sagantole & & & $(149.0)^{\mathrm{h}}$ & $(74.0)^{\mathrm{h}}$ & $(47.0)^{\mathrm{h}}$ & & $(64)^{\mathrm{h}}$ & $(4.5)^{\mathrm{h}}$ & $(39)^{\mathrm{h}}$ & & \\
\hline \multicolumn{12}{|l|}{ Fm., $P$. } \\
\hline \multicolumn{12}{|l|}{ "gomphotheroides } \\
\hline \multicolumn{12}{|l|}{ gomphotheroides" } \\
\hline \multicolumn{12}{|l|}{ (=korotorensis), KL-211- } \\
\hline $2^{\mathrm{d}}$ & & & & & & & & & & & \\
\hline
\end{tabular}


Middle Awash, Ethiopia, M2

Asa-Koma Mb., Adu-Asa

Fm., $P$.

"gomphotheroides

saitunensis"

(=korotorensis), ASK-

$\mathrm{VP}-3 / 16^{\mathrm{q}}$

Middle Awash, Ethiopia, $\quad$ M2

$\times 5 x$

Asa-Koma Mb., Adu-Asa

Fm., $P$.

"gomphotheroides

saitunensis"

(=korotorensis), STD-

VP- $2 / 85^{\mathrm{q}}$ $\mathrm{x} 5 \mathrm{x}$

148.5

95.7$$
\text { 4.6-5.1 }
$$

64

up to 8 apical

digitations 


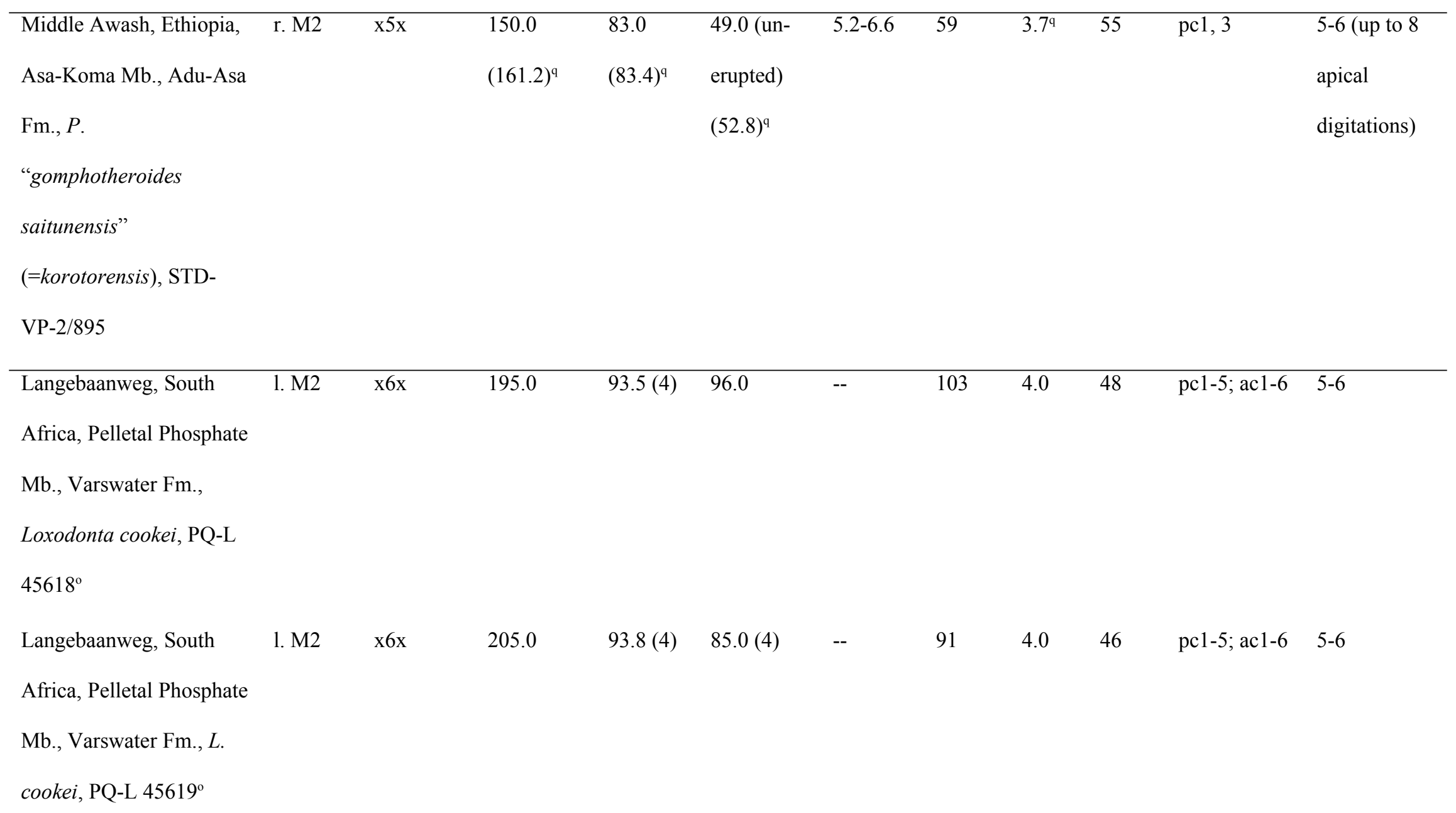


Langebaanweg, South

r. M2

$x 6 x$

Africa, Pelletal Phosphate

Mb., Varswater Fm.,

Loxodonta cookei, PQ-L

45627 (type) $^{\circ}$

Langebaanweg, South

1. M2 $x 6 x$

155.0

$75.0(3)$

worn

3.0

$--$

5.0

48

pc1-5; ac1-6

$5-6$

Africa, Pelletal Phosphate

Mb., Varswater Fm.,

Loxodonta cookei, PQ-L

$69077^{\circ}$

Western Rift, Uganda,

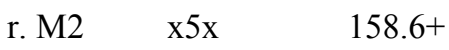

$82.1(3)$

$68.5(5)$

3.9

84

3.3

pc2, ac1-4

5

Warwire Fm., L. cookei,

NK 252’86

Western Rift, Uganda,

1. M2 $\quad x 5 x \quad 167.0$

$82.6(4) \quad 71.0(5)$

4.3

86

49

pc1-4, ac1-4 5

Warwire Fm., L. cookei,

NK 253'86 


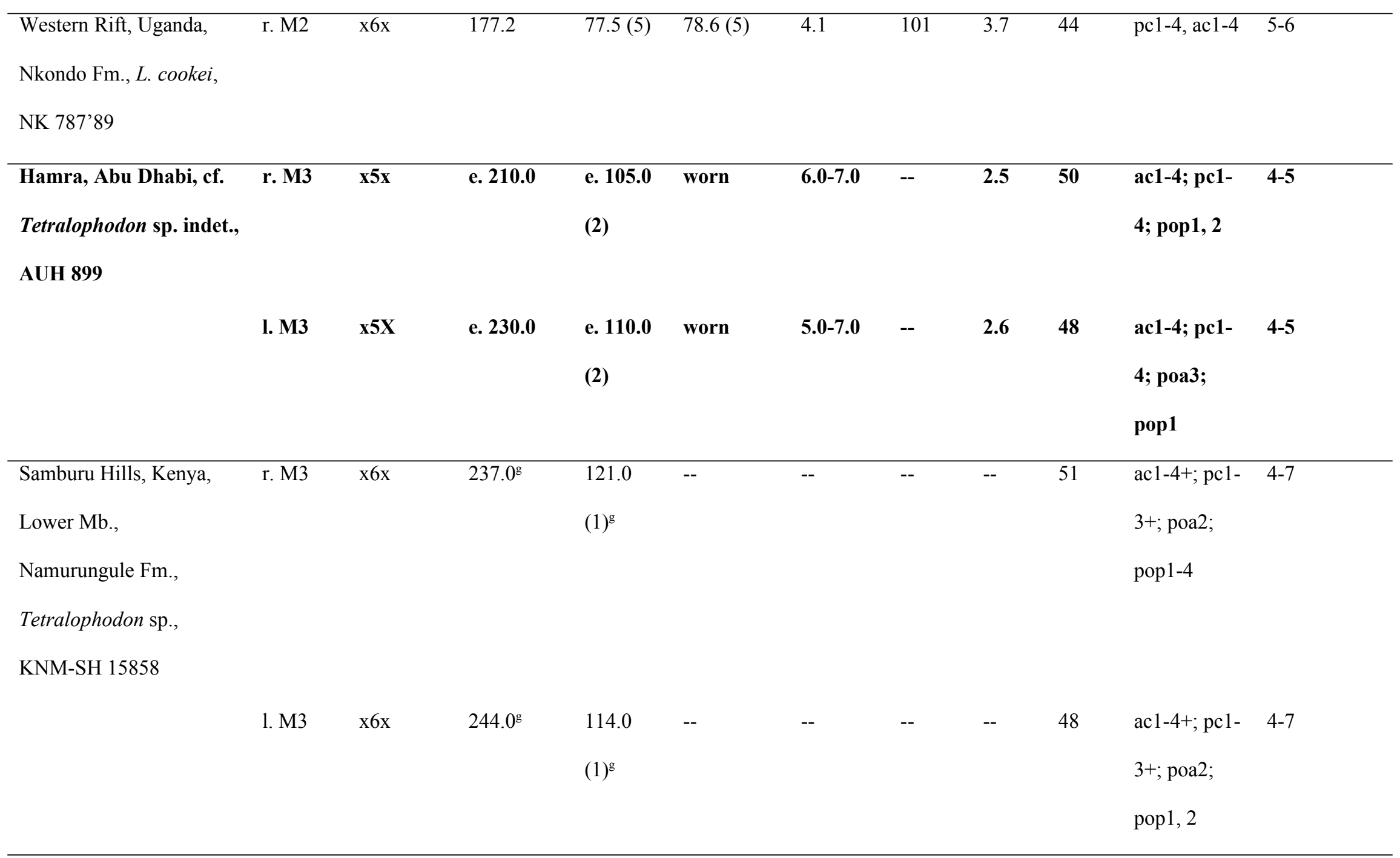




\begin{tabular}{|c|c|c|c|c|c|c|c|c|c|c|c|}
\hline Kisegi-Nyabusosi Area, & 1. M3 & $x 5 x$ & 225.6 & 111.6 & $61.0(4)$ & -- & 55 & 2.6 & 49 & ac1-4; pc1- & $4-5$ \\
\hline Tetralophodon sp. & & & & $(109.4$ & this study) & this & this & this & & & \\
\hline (=Elephantidae, primitive & & & & (1); this & & study) & study) & study) & & & \\
\hline form, gen. et sp. incertae & & & & study) & & & & & & & \\
\hline Sahabi, Libya, & 1. M3 & $6 \mathrm{x}$ & $250.0+$ & 121.0 & -- & -- & -- & -- & -- & pc1-3 & $4-5$ \\
\hline \multicolumn{12}{|l|}{ Stegotetrabelodon } \\
\hline \multicolumn{12}{|l|}{ syrticus, Petrocchi } \\
\hline \multicolumn{12}{|l|}{ collection no \# \#, b } \\
\hline \multicolumn{12}{|l|}{ syrticus, Petrocchi } \\
\hline \multicolumn{12}{|l|}{ collection no \# $\#^{\mathrm{a}, \mathrm{b}}$} \\
\hline Sahabi, Libya, S. syrticus & 1. M3 & $+6+$ & $+243.0+$ & 125.0 & 78.0 & -- & 62 & -- & -- & $\mathrm{pc} 1,2$ & $5-6$ \\
\hline (="Stegolophodon & & & & & & & & & & (doubled) & \\
\hline \multicolumn{12}{|l|}{ sahabianus"), Petrocchi } \\
\hline collection no $\#^{\mathrm{a}}$ & & & & & & & & & & & \\
\hline
\end{tabular}




\begin{tabular}{|c|c|c|c|c|c|c|c|c|c|c|c|}
\hline \multicolumn{12}{|l|}{$16 \mathrm{P} 87 \mathrm{~A}^{\mathrm{f}}$} \\
\hline \multirow{3}{*}{$\begin{array}{l}\text { Sahabi, Libya, S. syrticus, } \\
1 \text { P65 } \mathrm{A}^{\mathrm{f}}\end{array}$} & r. M3 & $x 6 x$ & 226.0 & 108.0 & -- & -- & -- & -- & 48 & pc1-3 & -- \\
\hline & & & & & & & & & & & \\
\hline & 1. M3 & $x 6 x$ & 224.0 & 105.0 & -- & -- & -- & -- & 47 & pc1-3 & -- \\
\hline Sahabi, Libya, S. syrticus, & r. M3 & $+3 \mathrm{x}$ & -- & $97.0+$ & -- & -- & -- & -- & -- & pc1-5 & $4-5$ \\
\hline \multicolumn{12}{|l|}{$30 \mathrm{P} 66 \mathrm{~A}^{\mathrm{f}}$} \\
\hline Lothagam, Kenya,? & r. M3 & $x 6 x$ & 238.2 & 104.3 & $74.0(1)$ & unworn & 71 & -- & 44 & $\mathrm{pc} 1,2$ & $4-5$ \\
\hline Apak/Upper Nawata Fm., & & & & (3) & & & & & & & \\
\hline \multicolumn{12}{|l|}{ Stegotetrabelodon orbus } \\
\hline \multicolumn{12}{|l|}{ (type), KNM-LT 354} \\
\hline Lothagam, Kenya, Lower & 1. M3 & $x 6 x$ & 207.5 & 110.2 & -- & $4.7-7.0$ & -- & 3.25 & 53 & pc1-4 (at & $4-5$ \\
\hline Nawata Fm., S. orbus, & & & & & & & & & & least) & \\
\hline \multicolumn{12}{|l|}{ KNM-LT 347} \\
\hline Lothagam, Kenya, lower & 1. M3 & $\mathrm{x} 6$ & 254.4 & 110.5 & $73.0(4)$ & $5.0-7.0$ & 66 & 2.75 & 43 & pc1-5 & 3-5 (as many \\
\hline Nawata Fm., S. orbus, & & & & (2) & & & & & & & as 7 apical \\
\hline KNM-LT 359 & & & & & & & & & & & digitations) \\
\hline
\end{tabular}




\begin{tabular}{|c|c|c|c|c|c|c|c|c|c|c|c|}
\hline Lothagam, Kenya, $S$. & r. M3 & $x 6 x$ & 235.0 & 106.0 & Worn & 5.7 & -- & 2.9 & 45 & pc1-4 & 4 \\
\hline orbus, KNM-LT 367 & & & & (3) & & & & & & & \\
\hline Lothagam, Kenya, Lower & 1. M3 & $x 6 x ?$ & e. 244.5 & 108.2 & e. $73.0(4)$ & $5.8-6.6$ & e. 67 & 3.0 & 44 & $\mathrm{pc} 1,2$ & $4-5$ \\
\hline Nawata Fm., S. orbus?, & & & & (2) & & & & & & & \\
\hline \multicolumn{12}{|l|}{ KNM-LT 26318} \\
\hline Lothagam, Kenya, & r. M3 & $\mathrm{x} 7 \mathrm{x}$ & 208.0 & $94.3(3)$ & $60.1(4)$ & $4.3-5.6$ & 64 & 3.2 & 45 & $\mathrm{pc} 1,2$ & $4-7$ \\
\hline \multicolumn{12}{|l|}{ Lower Nawata Fm., } \\
\hline \multicolumn{12}{|l|}{ Primelephas korotorensis } \\
\hline \multicolumn{12}{|l|}{ (type), KNM-LT 351} \\
\hline & 1. M3 & $x 7 x$ & 208.4 & $93.0(3)$ & $59.0(4)$ & -- & 63 & 3.5 & 45 & $\mathrm{pc} 1,2$ & $4-5$ (up to 7 \\
\hline & & & & & & & & & & & apical \\
\hline & & & & & & & & & & & digitations) \\
\hline Tugen Hills, Kenya, & 1. M3 & $+7+$ & $+193.0+$ & $98.0+$ & 61.0 & $5.0-6.0$ & $<62$ & 3.7 & -- & pc1 & $5-7$ \\
\hline \multicolumn{12}{|l|}{ Lukeino Fm., $P$. } \\
\hline \multicolumn{12}{|l|}{ korotorensis, KNM-LU } \\
\hline 58 & & & & & & & & & & & \\
\hline
\end{tabular}


Tugen Hills, Kenya,

r. M3

$+5 \mathrm{x}$

$+116.4$

$82.2+$

Lukeino Fm., $P$.

korotorensis, KNM-LU

59

Tugen Hills, Kenya,

$+3 \mathrm{x}$

Chemeron Fm., $P$.

korotorensis, KNM-BC

35

Tugen Hills, Kenya,

1. M3

$x 7 x$

250.0

99.0

57.0

5.5-6.4

58

3.8

40

none

7

Chemeron Fm., $P$.

korotorensis, KNM-BC

377 


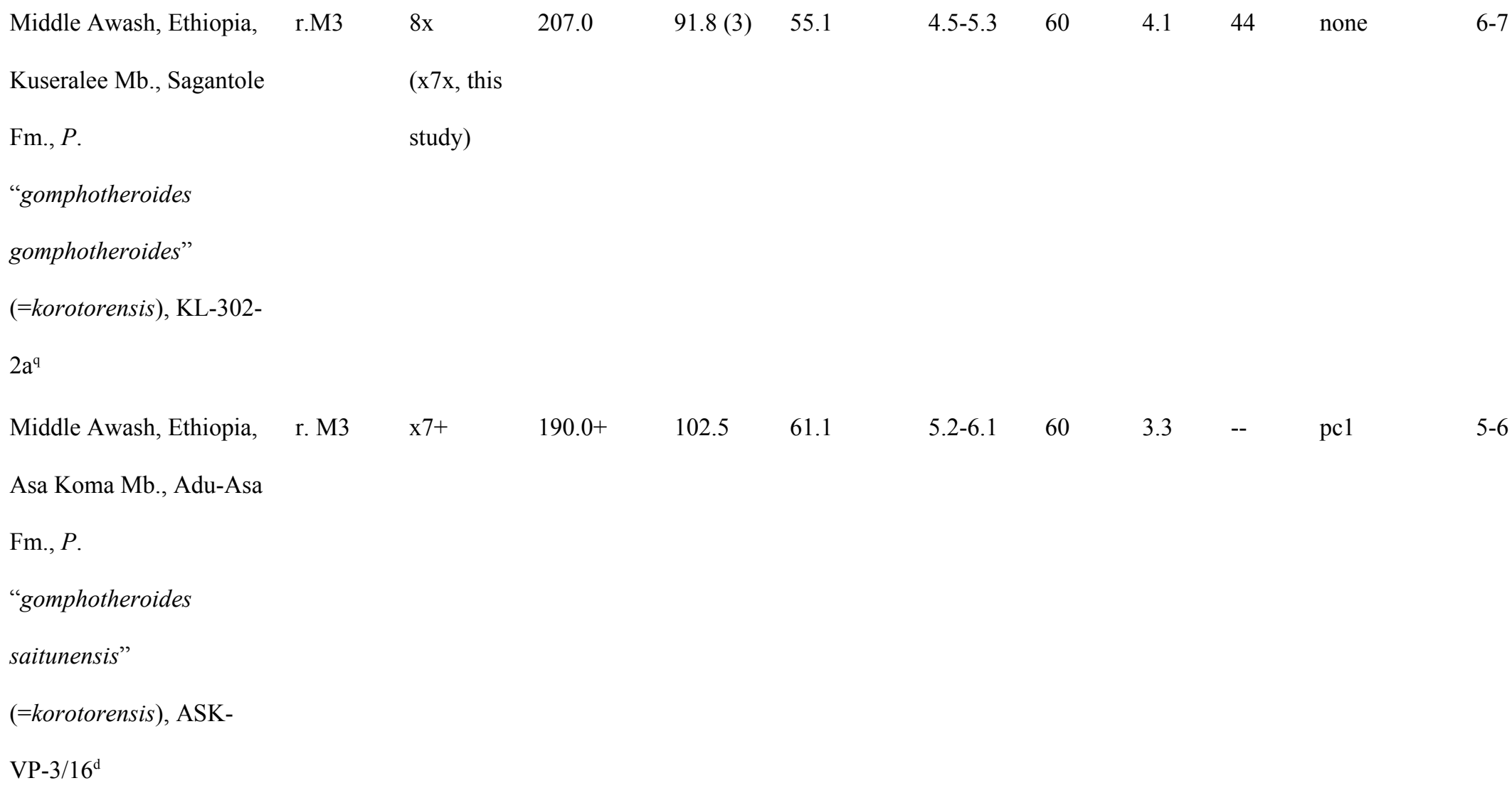

$8 \mathrm{x}$

207.0 $(\mathrm{x} 7 \mathrm{x}$, this

Kuseralee Mb., Sagantole

Fm., $P$.

"gomphotheroides

gomphotheroides"

(=korotorensis), KL-302-

$2 \mathrm{a}^{\mathrm{q}}$

Middle Awash, Ethiopia,

r. M3

$\mathrm{x} 7+$

$190.0+$

102.5

61.1

$5.2-6.1$

60

3.3

$\mathrm{pcl}$

Fm., $P$.

"gomphotheroides

saitunensis"

(=korotorensis), ASK-

VP-3/16 
Middle Awash, Ethiopia,

1. M3

$\mathrm{x} 7 \mathrm{x}$

212.2

Asa Koma Mb., Adu-Asa

Fm., $P$.

"gomphotheroides

saitunensis"

(=korotorensis), STD-

VP-2/896

1. M3

$\mathrm{x} 7 \mathrm{x}$

210.0
235.0

Manonga, Tanzania,

Ibole Mb., Wembere-

Manonga Fm., $P$.

korotorensis, WM 1093 -

92

$x 7 x$

$2^{\mathrm{j}}$
$104.5 \quad 62$.

$$
62.0
$$

83.5

56.6 (un-

5.4

68

3.4

43

pc1, 2

5-7

erupted)

54.6

58

3.2

40

4 
Shoshamagai 2,

Manonga, Tanzania,

Ibole Mb., Wembere-

Manonga Fm., $P$.

korotorensis, WM 1099-

92

Shoshamagai 2 ,

Manonga, Tanzania,

Ibole Mb., Wembere-

Manonga Fm., $P$.

korotorensis, WM 1794

$92^{\mathrm{j}}$

Kolinga, Chad, $P$.

$\mathrm{x} 7 \mathrm{x}$

$+227.0$

104.0

53.0

$5.0-5.5$

5

3

$4-5$

korotorensis, TM

$177.01 .043^{\mathrm{p}}$

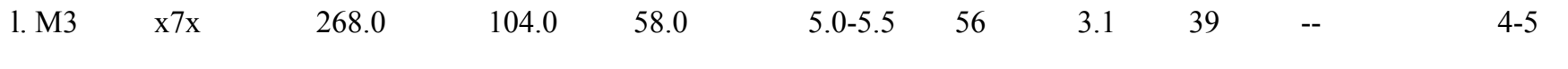




\begin{tabular}{|c|c|c|c|c|c|c|c|c|c|c|c|}
\hline Western Rift, Uganda, & r. M3 & $7 x$ & 202.0 & $86.4(3)$ & worn & $4.5-4.7$ & -- & 3.5 & 43 & pc1-5, ac1-6 & $3-5$ \\
\hline \multicolumn{12}{|l|}{ Nkondo Fm., Loxodonta } \\
\hline \multicolumn{12}{|l|}{ cookei, NK 62'89 } \\
\hline Tugen Hills, Kenya, & r. M3 & $x 7 x$ & 235.0 & $92.2(4)$ & worn & 4.0 & -- & 4.0 & 39 & pc1-6, ac1-6 & as many as 7 \\
\hline \multicolumn{12}{|l|}{ Chemeron Fm., L. cookei, } \\
\hline \multicolumn{12}{|l|}{ KNM-BC 189} \\
\hline Middle Awash, Ethiopia, & 1. M3 & $+5+$ & $+154.0+$ & 102.0 & 91.0 & $2.0-4.0$ & 89 & 3.5 & -- & -- & 6 \\
\hline \multicolumn{12}{|l|}{ Mammuthus } \\
\hline \multicolumn{12}{|l|}{ subplanifrons, L27-1 $\mathrm{b}^{\mathrm{h}}$} \\
\hline Jebel Mimiyah, Abu & r. dp4 & $\mathbf{x 5 X}$ & -- & e. 48.0 & worn & 3.1-3.3 & -- & e. 3.0 & -- & ac1-5; pc 1- & $5-7$ \\
\hline Dhabi, & & (broken & & (4) & & & & & & 4 & \\
\hline Stegotetrabelodon [sp. & & through & & & & & & & & & \\
\hline novl, sp. nov., AUH & & plates 2- & & & & & & & & & \\
\hline \multirow[t]{2}{*}{1779} & & 3) & & & & & & & & & \\
\hline & l. dp4 & $\mathbf{x} 5 X$ & e. 102 & $49.9(4)$ & worn & 3.1-3.3 & -- & 3.0 & e. 49 & ac1-5; pc1-5 & $5-6$ \\
\hline Sahabi, & r. dp4 & $x 4 x$ & 100.0 & $51.0(3)$ & -- & -- & -- & -- & 51 & ac1-4; pc1-3 & $4-5$ \\
\hline
\end{tabular}

Stegotetrabelodon

syrticus, 198P34A ${ }^{\mathrm{f}}$ 


\begin{tabular}{|c|c|c|c|c|c|c|c|c|c|c|c|}
\hline $\begin{array}{l}\text { Sahabi, S. syrticus, } \\
5 \mathrm{P} 15 \mathrm{~A}^{\mathrm{f}}\end{array}$ & 1. $\mathrm{dp} 4$ & $x 4 x$ & e.95.0 & -- & -- & -- & -- & -- & -- & ac1-4; pc1-3 & -- \\
\hline Tugen Hills, Kenya, & r. dp4 & $+5 x$ & +98.8 & $54.1(4)$ & $31.0(4)$ & -- & 57 & -- & -- & $\mathrm{pc} 1-4(\mathrm{pc} 2$ & $4-7$ \\
\hline Lukeino Fm., & & & & & & & & & & doubled) & \\
\hline \multicolumn{12}{|l|}{ Primelephas } \\
\hline \multicolumn{12}{|l|}{ korotorensis, KNM-LU } \\
\hline \multicolumn{12}{|l|}{694} \\
\hline Middle Awash, Ethiopia, & 1. dp4 & $x 5 x$ & 100.9 & 55.2 & 33.8 & 2.4 & 61 & -- & 55 & pc1-3 & $6-9$ \\
\hline \multicolumn{12}{|l|}{ Asa Koma Mb., Adu-Asa } \\
\hline \multicolumn{12}{|l|}{ Fm., Primelephas } \\
\hline \multicolumn{12}{|l|}{ "gomphotheroides } \\
\hline \multicolumn{12}{|l|}{ saitunensis" } \\
\hline \multicolumn{12}{|l|}{ (=korotorensis), KL-89- } \\
\hline $5^{\mathrm{q}}$ & & & & & & & & & & & \\
\hline
\end{tabular}




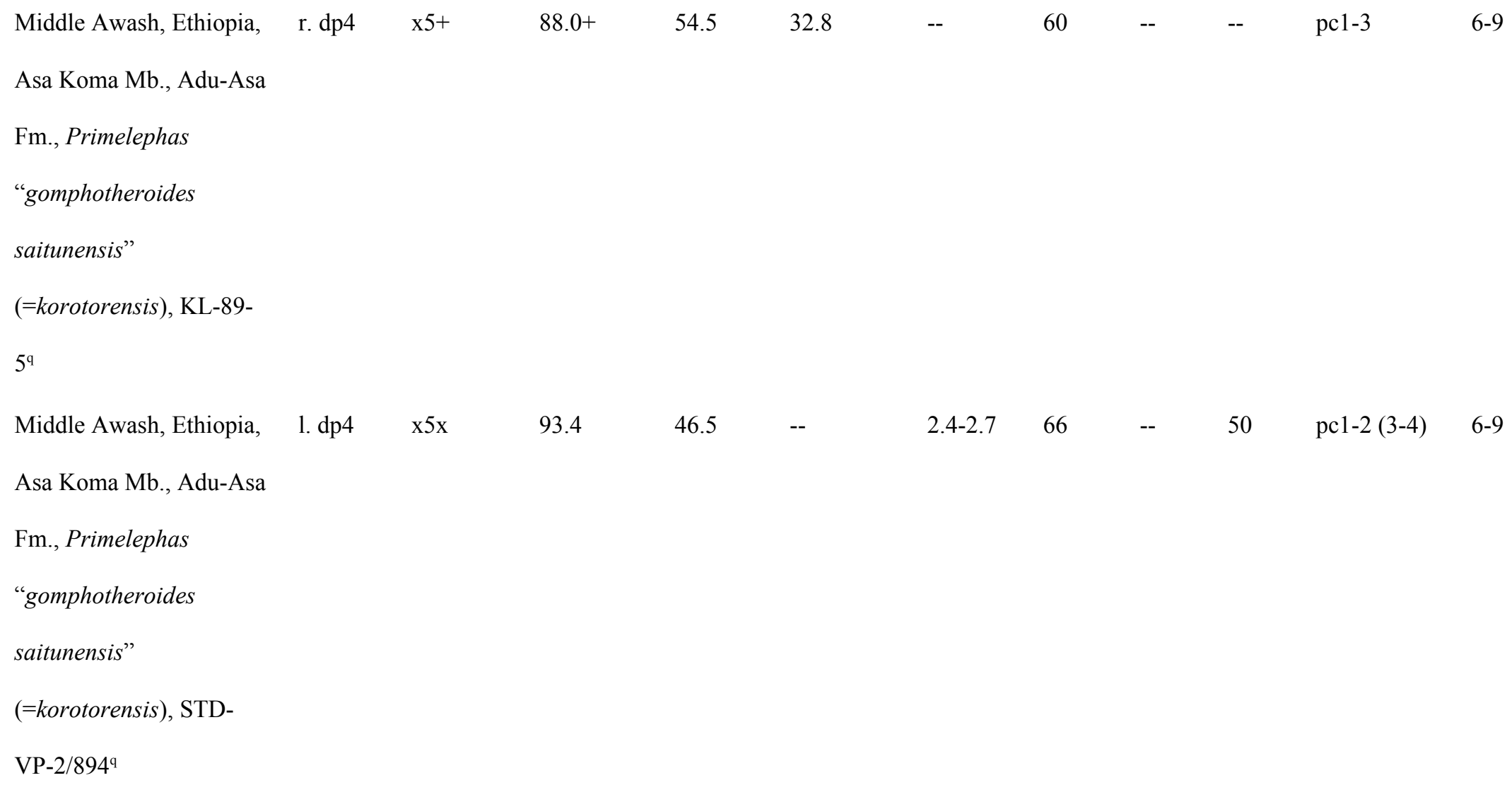

Asa Koma Mb., Adu-Asa

Fm., Primelephas

“gomphotheroides

saitunensis"

(=korotorensis), KL-89-

$5^{\mathrm{q}}$

$\begin{array}{ll}x 5 x & 93.4\end{array}$

46.5

$2.4-2.7$

66

pc1-2 (3-4)

6-9

Asa Koma Mb., Adu-Asa

Fm., Primelephas

"gomphotheroides

saitunensis"

(=korotorensis), STD-

VP-2/894 


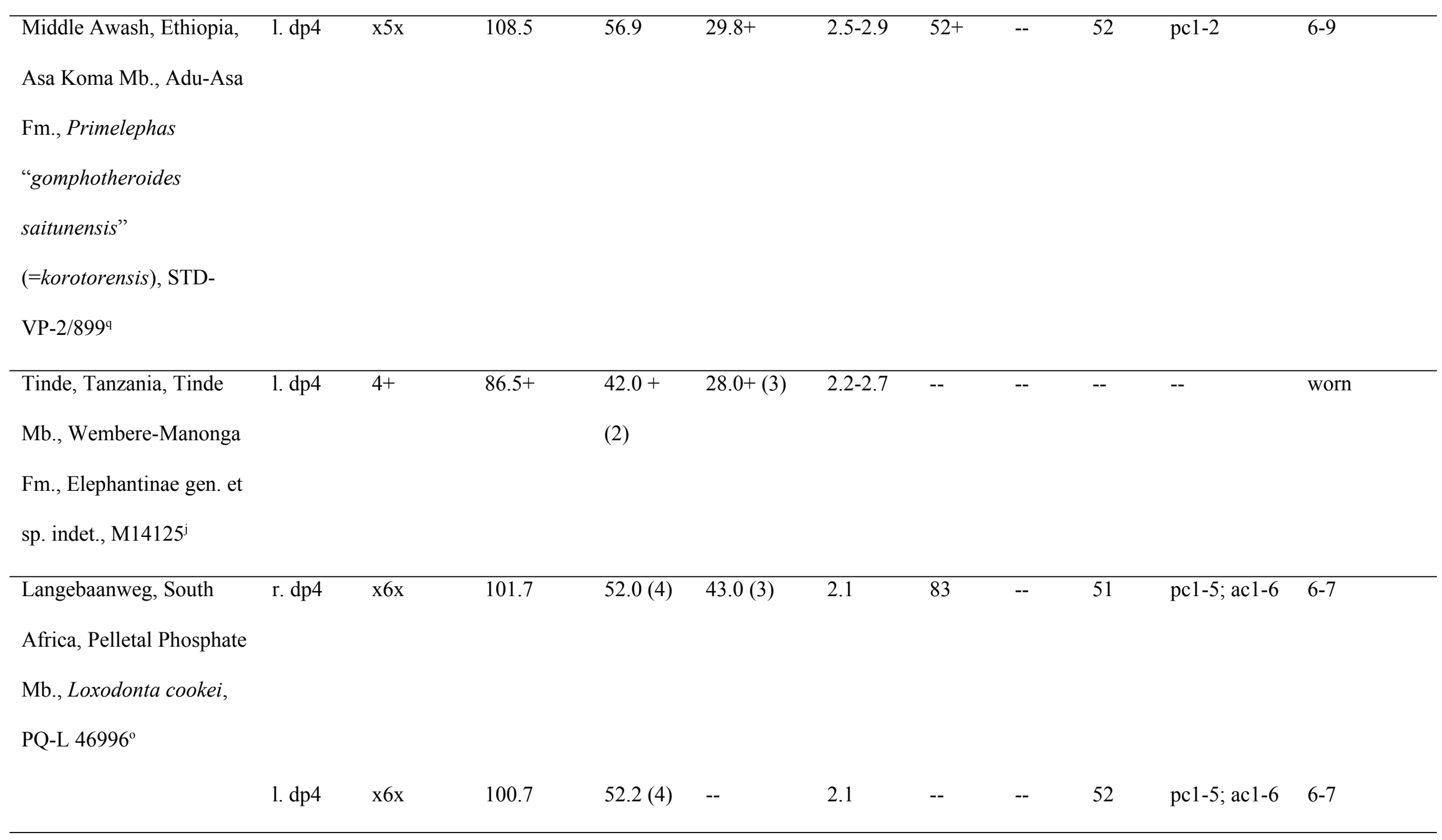




\begin{tabular}{|c|c|c|c|c|c|c|c|c|c|c|c|}
\hline Jebel Mimiyah, Abu & r.p3 & $\mathbf{x} 3 \mathbf{x}$ & 33.8 & $23.0(2)$ & $17.5(1)$ & -- & 76 & -- & 68 & -- & $2-4$ \\
\hline Stegotetrabelodon [sp. & & & & & & & & & & & \\
\hline novl, sp. nov., AUH & & & & & & & & & & & \\
\hline 1779 & & & & & & & & & & & \\
\hline Lothagam, Kenya, Lower & 1.p3 & $\mathrm{x} 3+$ & $33.5+$ & $24.6(2)$ & $12.3+$ & -- & -- & -- & -- & -- & $2-4$ \\
\hline Nawata Fm., & & $\left(x 3 x^{n}\right)$ & $\left(33.8^{\mathrm{n}}\right)$ & $\left(25.0^{\mathrm{n}}\right)$ & & & & & $\left(74^{\mathrm{n}}\right)$ & & \\
\hline Stegotetrabelodon orbus & & & & & & & & & & & \\
\hline Lothagam, Kenya, Lower & r.? p3 & $x 3 x$ & 32.8 & $25.7(2$ & $15.0+(2)$ & -- & $58+$ & -- & 78 & -- & $2-4$ \\
\hline Nawata Fm., S. orbus or & & & & 3) & & & & & & & \\
\hline P. korotorensis, KNM- & & & & & & & & & & & \\
\hline LT-26329n & & & & & & & & & & & \\
\hline
\end{tabular}


Middle Awash, Ethiopia, 1. p3

Asa Koma Mb., Adu-Asa

Fm., Primelephas

"gomphotheroides

saitunensis"

(=korotorensis), ALA-

VP-2/108

Middle Awash, Ethiopia, $\quad$ 1. p3

$\mathrm{x} 3 \mathrm{x}$

33.4

$25.2(2)$

17.3

69

Asa Koma Mb., Adu-Asa

Fm., Primelephas

"gomphotheroides

saitunensis"

(=korotorensis), STD-

VP-2/64

$22.5(2) \quad 12.2$

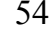

79 


\begin{tabular}{lllllllllll}
\hline Middle Awash, Ethiopia, & $1 . p 3$ & x3x & 26.4 & $21.8(3)$ & 14.4 & -- & 66 & -- & 83 & --
\end{tabular}

Asa Koma Mb., Adu-Asa

Fm., Primelephas

"gomphotheroides

saitunensis"

(=korotorensis), STD-

VP-2/6

\begin{tabular}{|c|c|c|c|c|c|c|c|c|c|c|c|}
\hline Tinde, Tanzania, Tinde & 1. p3 (in & $+2 \mathrm{x}$ & +18.0 & 21.0 & 17.0 & -- & 81 & -- & -- & -- & 4 \\
\hline Mb., Wembere-Manonga & crypt) & & & & & & & & & & \\
\hline \multicolumn{12}{|l|}{ Fm., Elephantinae gen. et } \\
\hline sp. indet., M14125 & & & & & & & & & & & \\
\hline
\end{tabular}

Africa, Pelletal Phosphate

Mb., Loxodonta cookei,

PQ-L $69067^{\circ}$ 


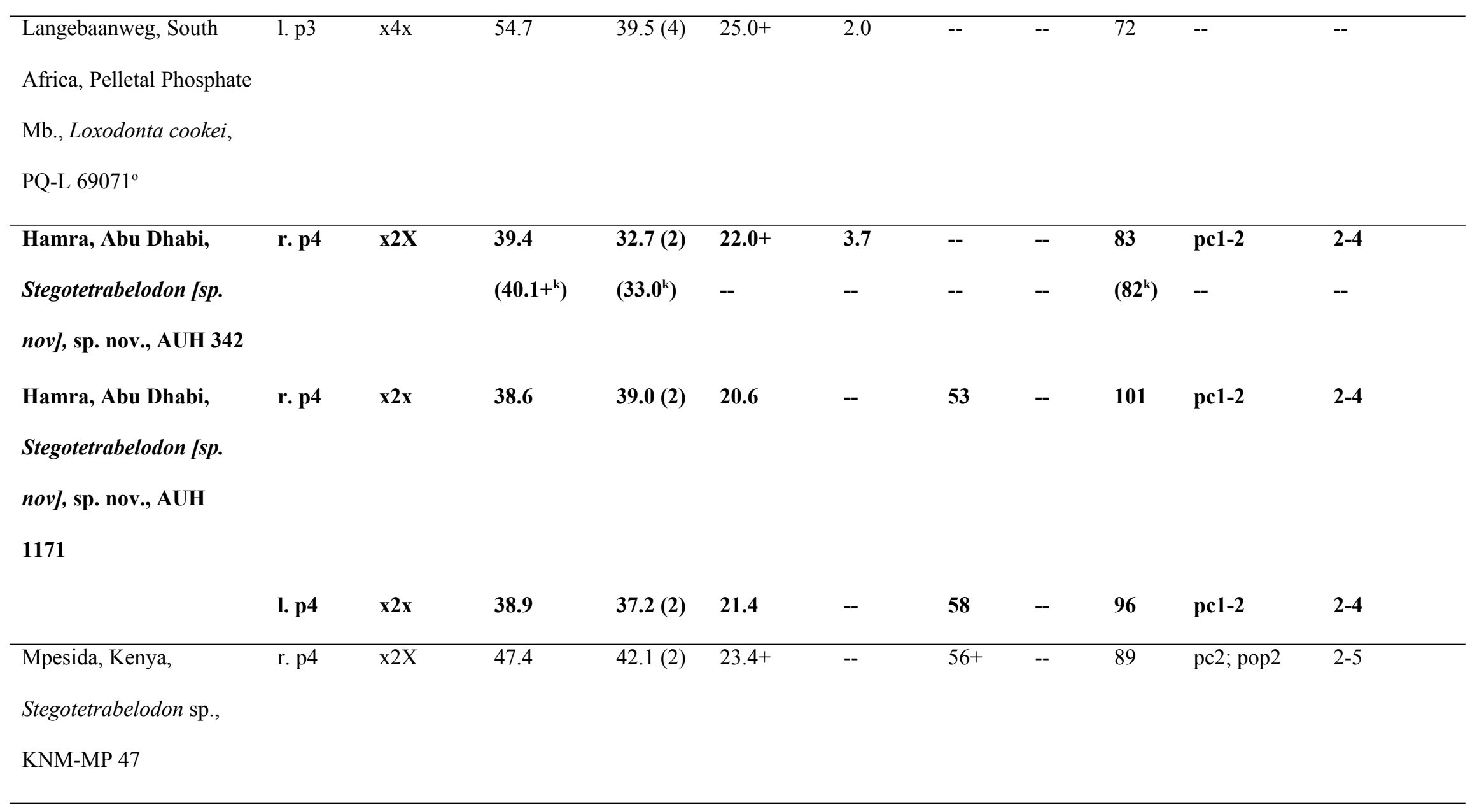




\begin{tabular}{|c|c|c|c|c|c|c|c|c|c|c|c|}
\hline Tugen Hills, Kenya, & 1. $\mathrm{p} 4$ & $\mathrm{x} 3 \mathrm{x}$ & 46.5 & $40.3(3)$ & $28.4+(1)$ & 3.5 & $70+$ & -- & 87 & -- & 4 \\
\hline \multicolumn{12}{|l|}{ Lukeino Fm., } \\
\hline \multicolumn{12}{|l|}{ Primelephas } \\
\hline \multicolumn{12}{|l|}{ korotorensis, KNM-LU } \\
\hline \multicolumn{12}{|l|}{925} \\
\hline Middle Awash, Ethiopia, & r. $\mathrm{p} 4$ & $\mathrm{x} 3$ & 44.2 & $40.0(3)$ & -- & -- & -- & -- & 91 & -- & $2-4$ \\
\hline \multicolumn{12}{|l|}{ Asa Koma Mb., Adu-Asa } \\
\hline \multicolumn{12}{|l|}{ Fm., Primelephas } \\
\hline \multicolumn{12}{|l|}{ "gomphotheroides } \\
\hline \multicolumn{12}{|l|}{ saitunensis" } \\
\hline \multicolumn{12}{|l|}{ (=korotorensis), STD- } \\
\hline \multicolumn{12}{|l|}{$\mathrm{VP}-2 / 86^{\mathrm{q}}$} \\
\hline Tinde, Tanzania, Tinde & r. p4 & $+2 \mathrm{x}$ & +32.7 & $38.6(\mathrm{I})$ & $19.7+(\mathrm{II})$ & $2.5-3.0$ & $51+$ & -- & -- & pc, pop, last & $3-4$ \\
\hline Mb., Wembere-Manonga & & & & & & & & & & lophid & \\
\hline \multicolumn{12}{|l|}{ Fm., Elephantinae gen. et } \\
\hline sp. indet., WM 83/94 & & & & & & & & & & & \\
\hline
\end{tabular}




\begin{tabular}{|c|c|c|c|c|c|c|c|c|c|c|c|}
\hline Langebaanweg, South & 1. $\mathrm{p} 4$ & $\mathrm{x} 4 \mathrm{x}$ & 66.0 & $47.4(3)$ & worn & $2.5-3.0$ & -- & -- & 72 & ac1-4; pc1-4 & $3-5$ \\
\hline \multicolumn{12}{|l|}{ Africa, Pelletal Phosphate } \\
\hline \multicolumn{12}{|l|}{ Mb., Loxodonta cookei, } \\
\hline \multicolumn{12}{|l|}{ PQ-L 45608 } \\
\hline Langebaanweg, South & 1. $\mathrm{p} 4$ & $x 4 x$ & 66.5 & 45.3 & worn & $3.2-3.7$ & -- & -- & 68 & -- & -- \\
\hline \multicolumn{12}{|l|}{ Mb., Loxodonta cookei, } \\
\hline \multicolumn{12}{|l|}{ PQ-L 45782 } \\
\hline Langebaanweg, South & 1. $\mathrm{p} 4$ & $x 4 x$ & 63.9 & 44.0 & worn & $2.4-3.3$ & -- & -- & 69 & -- & -- \\
\hline \multicolumn{12}{|l|}{ Mb., Loxodonta cookei, } \\
\hline Hamra, Abu Dhabi, & r. m1 & $x 5 x$ & 117.1 & $72.3(4)$ & worn & $4.2-4.5$ & -- & 4.75 & 62 & pc1-5 & worn; \\
\hline \multicolumn{12}{|l|}{ Stegotetrabelodon } \\
\hline \multirow{2}{*}{\multicolumn{12}{|c|}{ [sp. nov], sp. nov., }} \\
\hline & & & & & & & & & & & \\
\hline AUH 1171 & & & & & & & & & & & \\
\hline
\end{tabular}




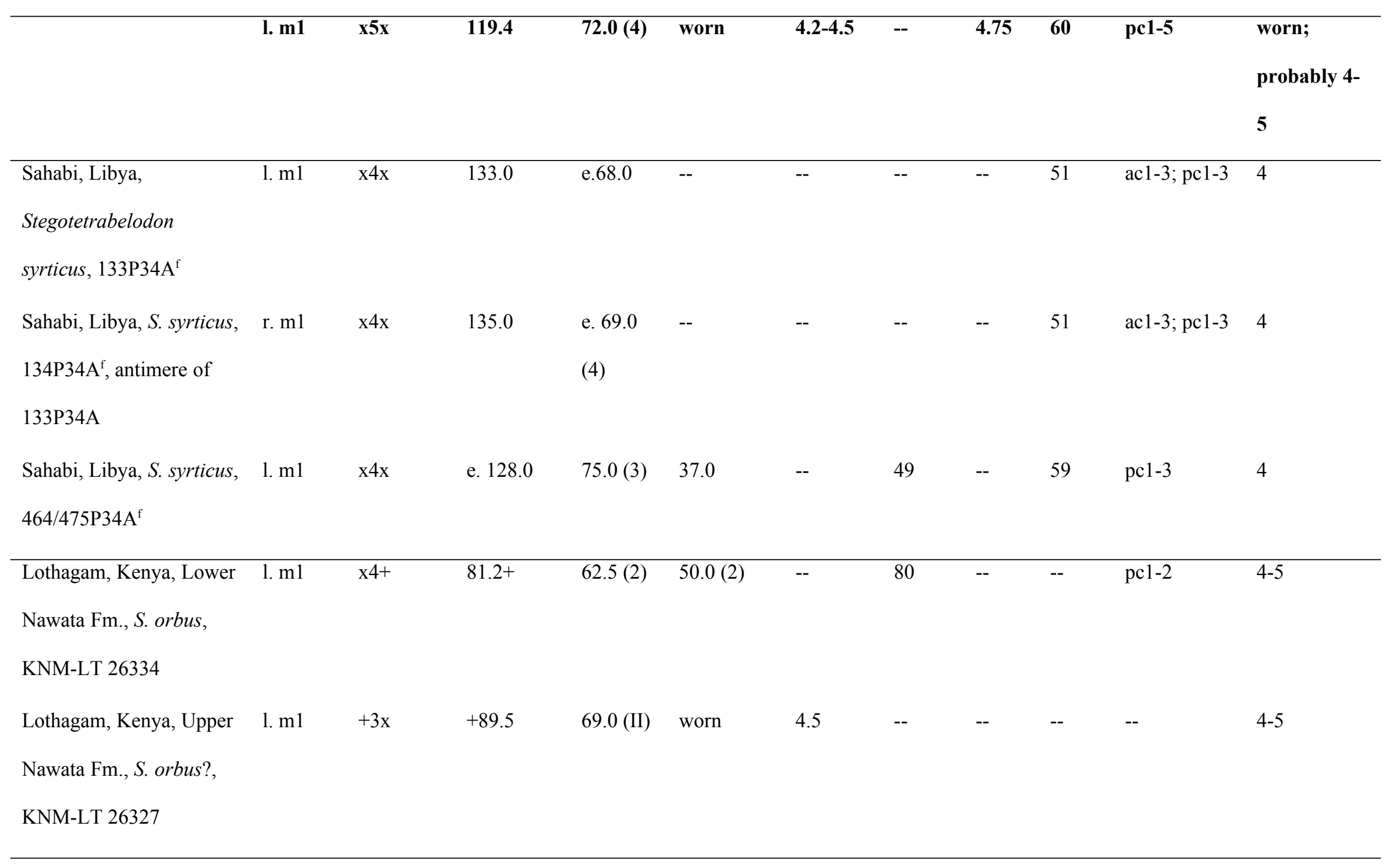




\begin{tabular}{|c|c|c|c|c|c|c|c|c|c|c|c|}
\hline \multirow{2}{*}{\multicolumn{12}{|c|}{ Lothagam, Kenya, Upper r. m1 }} \\
\hline & & & & & & & & & & & \\
\hline \multicolumn{12}{|l|}{ Nawata Fm., "Elephas } \\
\hline \multicolumn{12}{|l|}{ nawataensis" } \\
\hline \multicolumn{12}{|l|}{$(=$ Primelephas } \\
\hline \multicolumn{12}{|l|}{ korotorensis), KNM-LT } \\
\hline \multicolumn{12}{|l|}{23783} \\
\hline & 1. $\mathrm{m} 1$ & $\mathrm{x} 5 \mathrm{X}$ or $\mathrm{x} 6$ & 140.7 & $61.5(4)$ & $49.0(4)$ & 3.9 & 80 & -- & 44 & pc1 & $4-8$ \\
\hline Lothagam, Kenya, & r. m1 & $+5 \mathrm{x}$ & +122.0 & $63.5(4)$ & $40.6+$ & 3.0 & $64+$ & 4.0 & -- & pc1-4; ac2 & $4-6$ \\
\hline \multicolumn{12}{|l|}{ Horizon indet. ${ }^{n}$, Nawata } \\
\hline \multicolumn{12}{|l|}{ Fm., P. korotorensis, } \\
\hline \multicolumn{12}{|l|}{ KNM-LT 375} \\
\hline Lothagam, Kenya, Lower & r. $\mathrm{m} 1$ & $+5 \mathrm{x}$ & +109.1 & $61.0(4)$ & $32.0+$ & $3.0-4.0$ & $52+$ & 5.0 & -- & ac 4-5; pc1- & worn \\
\hline Nawata Fm., $P$. & & & & & & & & & & 4 & \\
\hline \multicolumn{12}{|l|}{ korotorensis, KNM-LT } \\
\hline 358 & & & & & & & & & & & \\
\hline
\end{tabular}




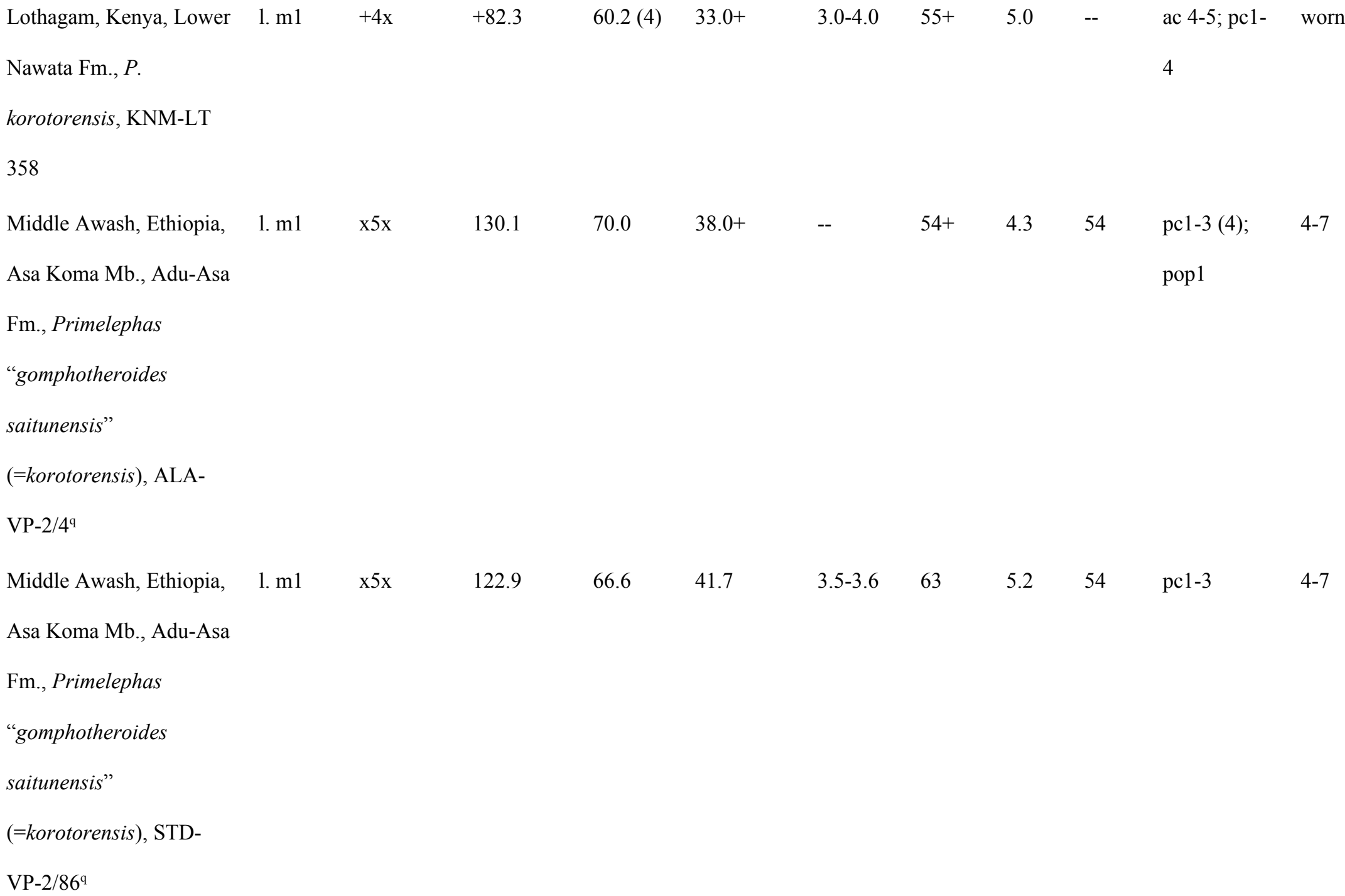

Nawata Fm., $P$.

korotorensis, KNM-LT

358

Middle Awash, Ethiopia, 1. m1 $\mathrm{x} 5 \mathrm{x}$

$38.0+$

$54+$

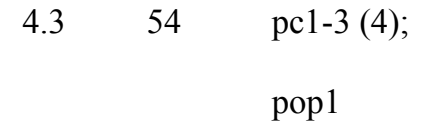

Asa Koma Mb., Adu-Asa

Fm., Primelephas

"gomphotheroides

saitunensis"

(=korotorensis), ALA-

$\mathrm{VP}-2 / 4^{\mathrm{q}}$

Middle Awash, Ethiopia, 1. $11 \quad \mathrm{x} 5 \mathrm{x}$

$x 5 x$

Asa Koma Mb., Adu-Asa

Fm., Primelephas

"gomphotheroides

saitunensis"

(=korotorensis), STD-

$\mathrm{VP}-2 / 86^{\mathrm{q}}$ 


\begin{tabular}{|c|c|c|c|c|c|c|c|c|c|c|c|}
\hline Middle Awash, Ethiopia, & 1. $\mathrm{m} 1$ & $x 5 x$ & 134.6 & 64.3 & -- & $3.2-3.6$ & -- & 4.1 & 48 & Expanded & worn \\
\hline Kuseralee Mb., Adu-Asa & & & & & & & & & & mesially anc & \\
\hline Fm., Loxodonta sp., & & & & & & & & & & distally in & \\
\hline \multirow[t]{7}{*}{ AME-VP-1/159q } & & & & & & & & & & midline & \\
\hline & & & & & & & & & & throughout & \\
\hline & & & & & & & & & & crown; too & \\
\hline & & & & & & & & & & worn to see & \\
\hline & & & & & & & & & & individual & \\
\hline & & & & & & & & & & accessory & \\
\hline & & & & & & & & & & conules & \\
\hline Jebel Barakah, Abu & 1. $? \mathrm{m3}$ & $+5 x$ & +190.4 & 87.2 & worn & 6.3-7.6 & -- & 3.0 & -- & acIII-IV; & $3-4$ \\
\hline Dhabi, & & & $195.6^{k}$ & (IV) & & & & & & pcII-V; & \\
\hline Gomphotheriidae gen. & & & & $88.2^{\mathrm{k}}$ & & & & & & poaIV; & \\
\hline et sp. indet., 1965 I 112 & & & & & & & & & & popIII-V & \\
\hline Sahabi, Libya, & r. $\mathrm{m} 3$ & $+6+$ & $+211.0+^{\mathrm{f}}$ & $85.0(3)^{\mathrm{f}}$ & $64.0(3)^{\mathrm{f}}$ & -- & 75 & -- & -- & ac1-5; pc1- & $3-4$ \\
\hline Konobelodon cyrenaicus, & & & & & & & & & & $5 ;$ pop $1-5$ & \\
\hline 200P15A & & & & & & & & & & & \\
\hline
\end{tabular}




\begin{tabular}{|c|c|c|c|c|c|c|c|c|c|c|c|}
\hline $\begin{array}{l}\text { Chorora, Awash Basin, } \\
\text { Ethiopia, ?Tetralophodon }\end{array}$ & r. m3 & $+x 6 x$ & $+183.0^{\mathrm{c}}$ & $86.5(3)^{\mathrm{c}}$ & -- & -- & -- & -- & -- & $\begin{array}{l}\text { ac1-4; pc1- } \\
\text { 5; pop1-5 }\end{array}$ & $3-4$ \\
\hline \multicolumn{12}{|l|}{ sp., } \\
\hline \multicolumn{12}{|l|}{ Stegotetrabelodon n. sp. ${ }^{1}$} \\
\hline \multicolumn{12}{|l|}{ Proboscidea indet. $^{\mathrm{c}}, \mathrm{AL}$} \\
\hline \multicolumn{12}{|l|}{$1000-1$} \\
\hline Ras Dubay’ah, Abu & r. $\mathbf{m 3}$ & $\mathbf{x 8 x}$ & $277.0^{k}$ & 109.1 & $62.0^{k}$ & $6.6^{k}$ & $56^{k}$ & $3.0^{k}$ & 39 & ac2, 3; pc1- & $3-5$ \\
\hline Dhabi, & & & & $(4)^{k}$ & & & & & & 6 & \\
\hline \multicolumn{12}{|l|}{ Stegotetrabelodon } \\
\hline \multicolumn{12}{|l|}{ [sp. nov], sp. nov., } \\
\hline \multicolumn{12}{|l|}{ AUH 456 (type) } \\
\hline Sahabi, Libya, & r. m3 & $\mathrm{x} 7 \mathrm{x}$ & 280.0 & 112.0 & $70.0(6)$ & -- & 63 & 3.0 & 40 & pc1-6 & $3-5$ \\
\hline Stegotetrabelodon & & & & (3) & & & & & & & \\
\hline syrticus, $1 \mathrm{P} 26 \mathrm{~A}^{\mathrm{f}}$ & & & & & & & & & & & \\
\hline Sahabi, Libya, S. syrticus, & r. $\mathrm{m} 3$ & $x 7 x$ & e. 267.0 & e.99.0 & $62.0(6)$ & -- & 63 & -- & 37 & pc1-4; pop4 & $3-5$ \\
\hline $17 \mathrm{P} 87 \mathrm{~A}^{\mathrm{f}}$ & & & & (4) & & & & & & & \\
\hline
\end{tabular}




\begin{tabular}{|c|c|c|c|c|c|c|c|c|c|c|c|}
\hline Sahabi, Libya, S. syrticus, & 1. $\mathrm{m} 3$ & $7 \mathrm{x}$ & 260.0 & 121.0 & -- & -- & -- & -- & & $\mathrm{pc} 1-5$ & $3-5$ \\
\hline no $\#^{\mathrm{b}}$ & & & & (4) & & & & & & & \\
\hline Sahabi, Libya, S. syrticus, & r. m3 & $7 \mathrm{x}$ & 280.0 & 119.0 & -- & -- & -- & -- & & $\mathrm{pc} 1-5$ & $3-5$ \\
\hline no $\#^{\mathrm{b}}$ & & & & $(5)$ & & & & & & & \\
\hline \multirow[t]{4}{*}{ Cessaniti, Italy, $S$. } & r. m3 & $7 \mathrm{x}$ & 254.0 & 104.0 & worn & $4.0-5.0$ & -- & -- & 41 & pc1 (pc2-7); & 4 \\
\hline & & & & (5) & & & & & & pop1 & \\
\hline & 1. $\mathrm{m} 3$ & $7 \mathrm{x}$ & 254.0 & 107.0 & worn & $4.0-5.0$ & -- & -- & 42 & pc1 (pc2-7); & 4 \\
\hline & & & & $(5)$ & & & & & & pop1 & \\
\hline Lothagam, Kenya,? & $1 . \mathrm{m} 3$ & $7 \mathrm{x}$ & 276.7 & $92.5(5)$ & 88.0 & 6.0 & -- & 3.0 & 33 & pc1-4 & 4 (up to 6 \\
\hline Apak/Upper Nawata Fm., & & & & & & & & & & & apical \\
\hline Stegotetrabelodon orbus & & & & & & & & & & & digitations) \\
\hline \multicolumn{12}{|l|}{ (type), KNM-LT 354} \\
\hline Lubeho, Manonga, & r. m3 & $\mathrm{x} 4+$ & $119.3+$ & 107.6 & $66.2+$ & $4.4-5.4$ & $61.5+$ & 3.0 & -- & ac1; pc1-3+ & $4-5$ \\
\hline \multicolumn{12}{|l|}{ Tanzania, Ibole Mb., } \\
\hline \multicolumn{12}{|l|}{ Wembere-Manonga Fm., } \\
\hline \multicolumn{12}{|l|}{ S. orbus, WM 110-94' } \\
\hline & 1. m3 & $\mathrm{x} 5+$ & $160.0+$ & $99.2+$ & -- & $4.8-5.1$ & -- & 3.0 & -- & -- & $4-5$ \\
\hline
\end{tabular}




\begin{tabular}{|c|c|c|c|c|c|c|c|c|c|c|c|}
\hline Kisegi, Uganda, Kakara & r. $\mathrm{m} 3$ & $+6 \mathrm{x}$ & -- & 94.0 & $52.0(\mathrm{I})$ & 6.8 & 66 & 3.8 & -- & pc1 & $3-5$ \\
\hline \multicolumn{12}{|l|}{ Fm., Stegotetrabelodon } \\
\hline \multicolumn{12}{|l|}{ sp., KI 102'92i } \\
\hline Nyabusosi, Uganda, & 1. $\mathrm{m} 3$ & $+8 \mathrm{x}$ & +241.6 & 102.0 & $81.0(5)$ & 5.4 & 79 & 3.0 & -- & ac2-4; pc1-3 & -- \\
\hline lower Oluka Fm., & & & & $(5)$ & & & & & & & \\
\hline \multicolumn{12}{|l|}{ Stegotetrabelodon sp., } \\
\hline \multicolumn{12}{|l|}{ NY $12^{\prime} 92^{i}$} \\
\hline Lothagam, Kenya, Lower & 1. $\mathrm{m} 3$ & $+8 \mathrm{x}$ & 249.5 & $93.1(3)$ & $61.0(5)$ & $3.5-5.0$ & 66 & 3.5 & 37 & pc1-3 & $3-5$ \\
\hline \multicolumn{12}{|l|}{ Nawata Fm., Primelephas } \\
\hline \multicolumn{12}{|l|}{ korotorensis (type), } \\
\hline \multicolumn{12}{|l|}{ KNM-LT 351} \\
\hline Tugen Hills, Kenya, & 1. $\mathrm{m} 3$ & $x 7 x$ & 237.0 & 98.0 & worn & $5.8-6.3$ & -- & 3.5 & 41 & none & $4-7$ \\
\hline \multicolumn{12}{|l|}{ Chemeron Fm., $P$. } \\
\hline \multicolumn{12}{|l|}{ korotorensis, KNM-BC } \\
\hline 378 & & & & & & & & & & & \\
\hline
\end{tabular}


Middle Awash, Ethiopia, m3

Kuseralee Mb., Sagantole

Fm., $P$.

"gomphotheroides

gomphotheroides"

(=korotorensis), KL-302-

$1^{\mathrm{q}}$

Middle Awash, Ethiopia,
Fm., $P$.

"gomphotheroides

saitunensis"

(=korotorensis), ASK-

$\mathrm{VP}-3 / 15^{\mathrm{q}}$ 
Middle Awash, Ethiopia, m3

$\mathrm{x} 8 \mathrm{x}$

Asa Koma Mb., Adu-Asa

Fm., $P$.

"gomphotheroides

saitunensis"

(=korotorensis), STD-

$\mathrm{VP}-2 / 833^{\mathrm{q}}$

Middle Awash, Ethiopia,

Asa Koma Mb., Adu-Asa

Fm., $P$.

"gomphotheroides

saitunensis"

(=korotorensis), STD-

VP-2/919q

Kolinga, Chad, $P$.

korotorensis,

TM16.97.003 


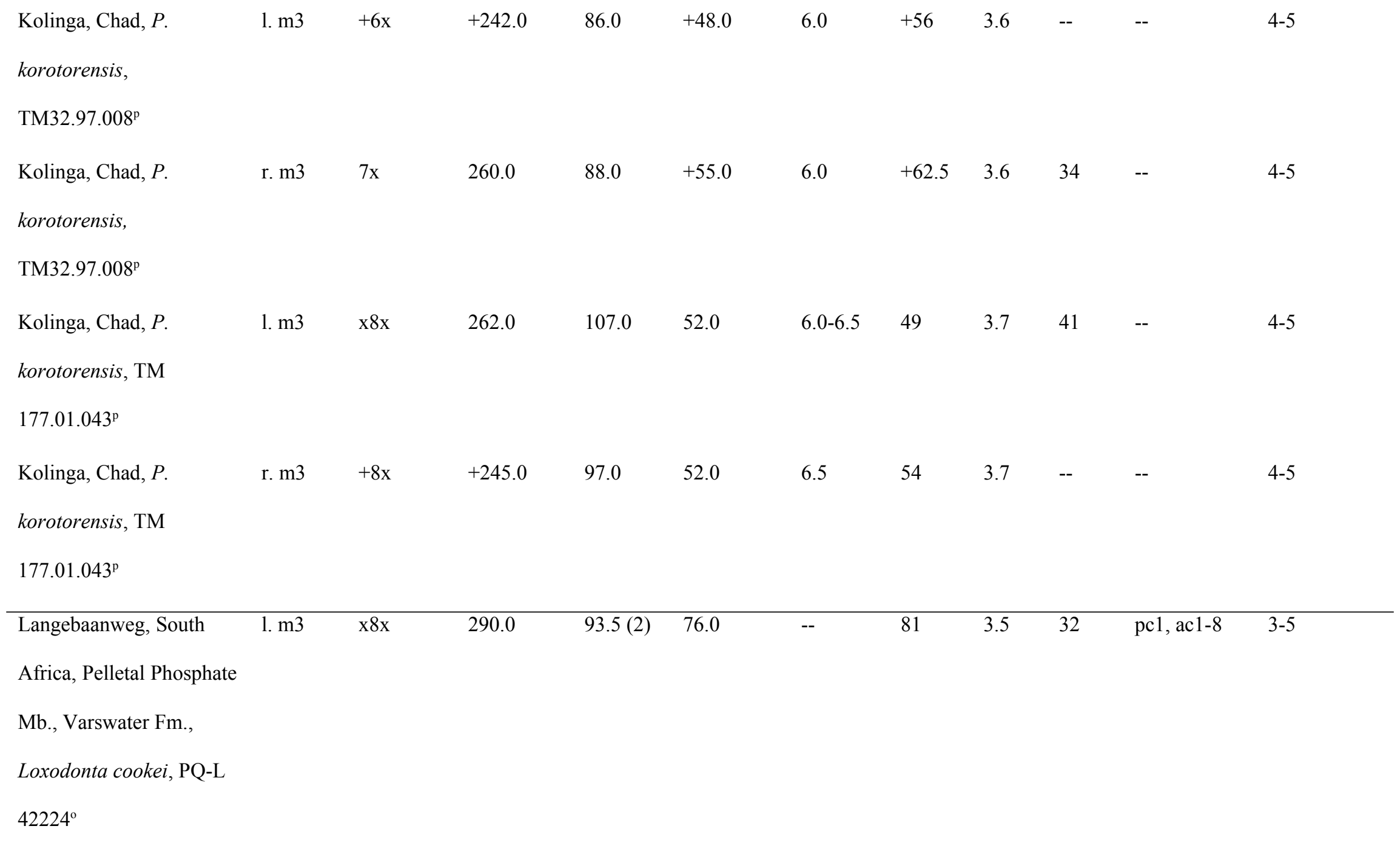


Langebaanweg, South

$$
\text { r. } \mathrm{m} 3
$$

$\mathrm{x} 8 \mathrm{x}$

Africa, Pelletal Phosphate

Mb., Varswater Fm., $L$.

cookei, PQ-L $45788^{\circ}$

\begin{tabular}{|c|c|c|c|c|c|c|c|c|c|c|}
\hline & 1. $\mathrm{m} 3$ & $x 8 x$ & 260.0 & $92.0(6)$ & worn & $4.9-6.2$ & -- & 4.0 & 35 & $\mathrm{pc} 1-8, \mathrm{ac} 1-8$ \\
\hline Tugen Hills Kenva & $r . m 3$ & $x 8 x$ & 2178 & 850 & worn & 38 & -- & 40 & 39 & \\
\hline
\end{tabular}

KNM-LU 67

Vaal River, South Africa,

r. m3

$+5 \mathrm{x}$

$+151.6$

101.4

worn

4.5

5-6

Mammuthus

subplanifrons (type),

MMK 3920

Virginia, South Africa,

1. $\mathrm{m} 3$

$+9 \mathrm{x}$

$+196.0$

91.0

worn

4.0-5.0

4.75

M. subplanifrons, A2882 


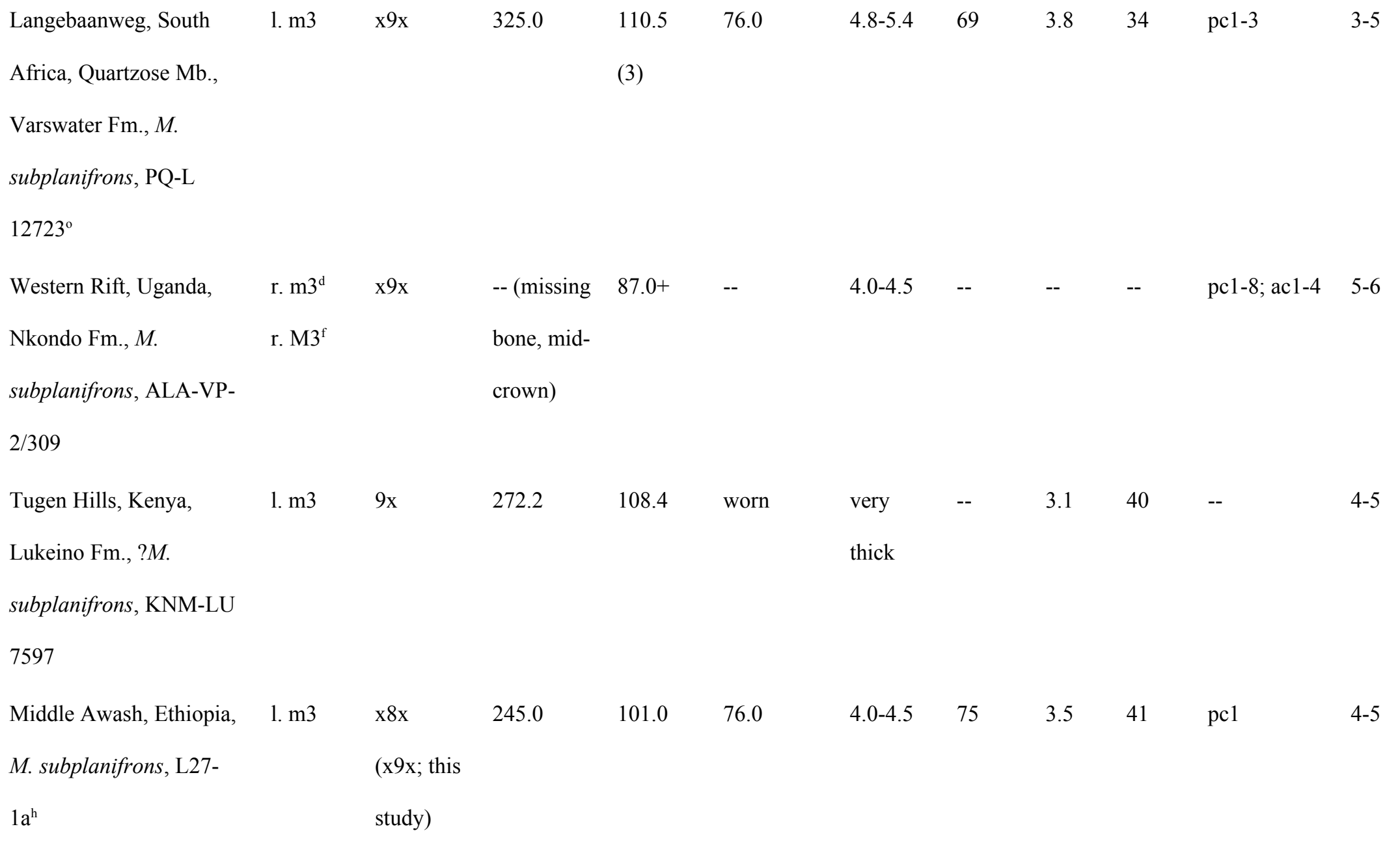

Africa, Quartzose Mb.,

(3)

Varswater Fm., $M$.

subplanifrons, PQ-L

$12723^{\circ}$

\begin{tabular}{|c|c|c|c|c|c|c|c|c|c|c|c|}
\hline Western Rift, Uganda, & r. $m 3^{d}$ & $x 9 x$ & -- (missing & $87.0+$ & -- & $4.0-4.5$ & -- & -- & -- & pc1-8; ac1-4 & $5-6$ \\
\hline Nkondo Fm., $M$. & r. $M 3^{f}$ & & bone, mid- & & & & & & & & \\
\hline subplanifrons, ALA-VP- & & & crown) & & & & & & & & \\
\hline \multicolumn{12}{|l|}{$2 / 309$} \\
\hline Tugen Hills, Kenya, & 1. $\mathrm{m} 3$ & $9 x$ & 272.2 & 108.4 & worn & very & -- & 3.1 & 40 & -- & $4-5$ \\
\hline Lukeino Fm., ?M. & & & & & & thick & & & & & \\
\hline \multicolumn{12}{|l|}{ subplanifrons, KNM-LU } \\
\hline \multicolumn{12}{|l|}{7597} \\
\hline Middle Awash, Ethiopia, & 1. $\mathrm{m} 3$ & $\mathrm{x} 8 \mathrm{x}$ & 245.0 & 101.0 & 76.0 & $4.0-4.5$ & 75 & 3.5 & 41 & $\mathrm{pc} 1$ & $4-5$ \\
\hline M. subplanifrons, L27- & & $(\mathrm{x} 9 \mathrm{x}$; this & & & & & & & & & \\
\hline $1 \mathrm{a}^{\mathrm{h}}$ & & study) & & & & & & & & & \\
\hline
\end{tabular}

${ }^{\text {aPetrocchi (1943) }}$

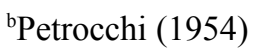


${ }^{c}$ Coppens and Tassy in Tiercelin et al. (1979)

${ }^{\mathrm{d}}$ Mebrate (1983)

'Nakaya et al. (1984)

${ }^{f}$ Gaziry (1987)

'Nakaya et al. (1987)

${ }^{\mathrm{h}}$ Kalb and Mebrate (1993)

'Tassy (1995)

jSanders (1997)

kTassy (1999)

${ }^{1}$ Geraads et al. (2002)

${ }^{\mathrm{m}}$ Ferretti et al. (2003)

${ }^{\mathrm{n}}$ Tassy (2003)

${ }^{\text {oSanders }}$ (2007)

${ }^{\mathrm{p}}$ Mackaye et al. (2008)

${ }^{q}$ Saegusa and Haile Selassie (2009) 
Fig 10.1

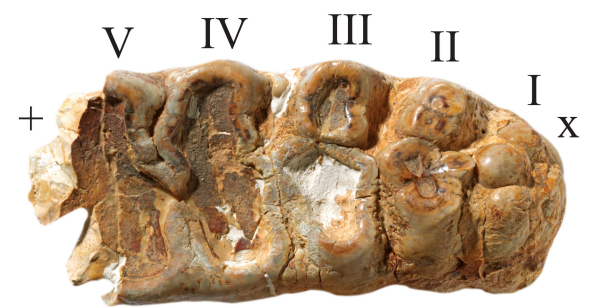

A

$1 \overline{\mathrm{cm}}$
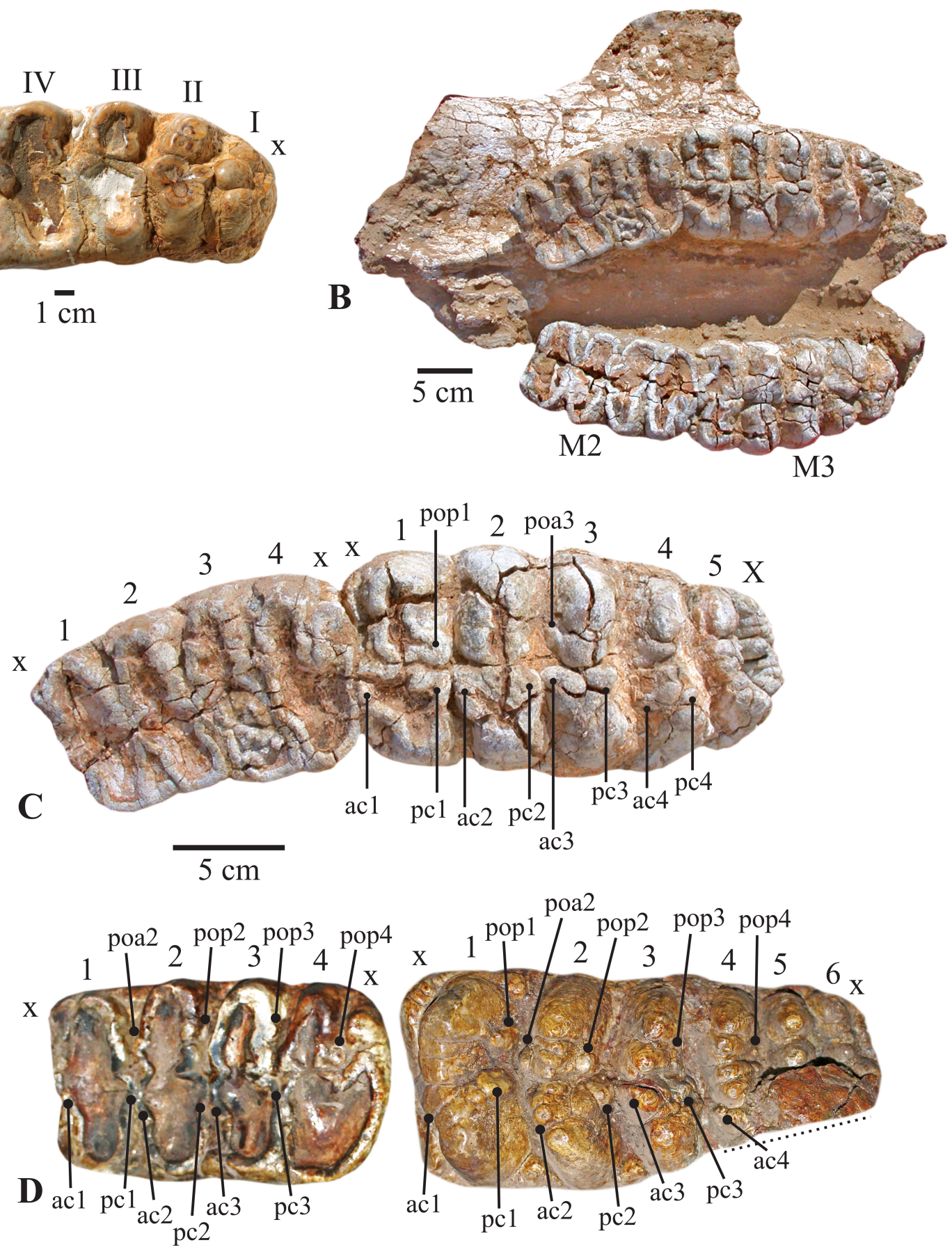
Fig 10.2
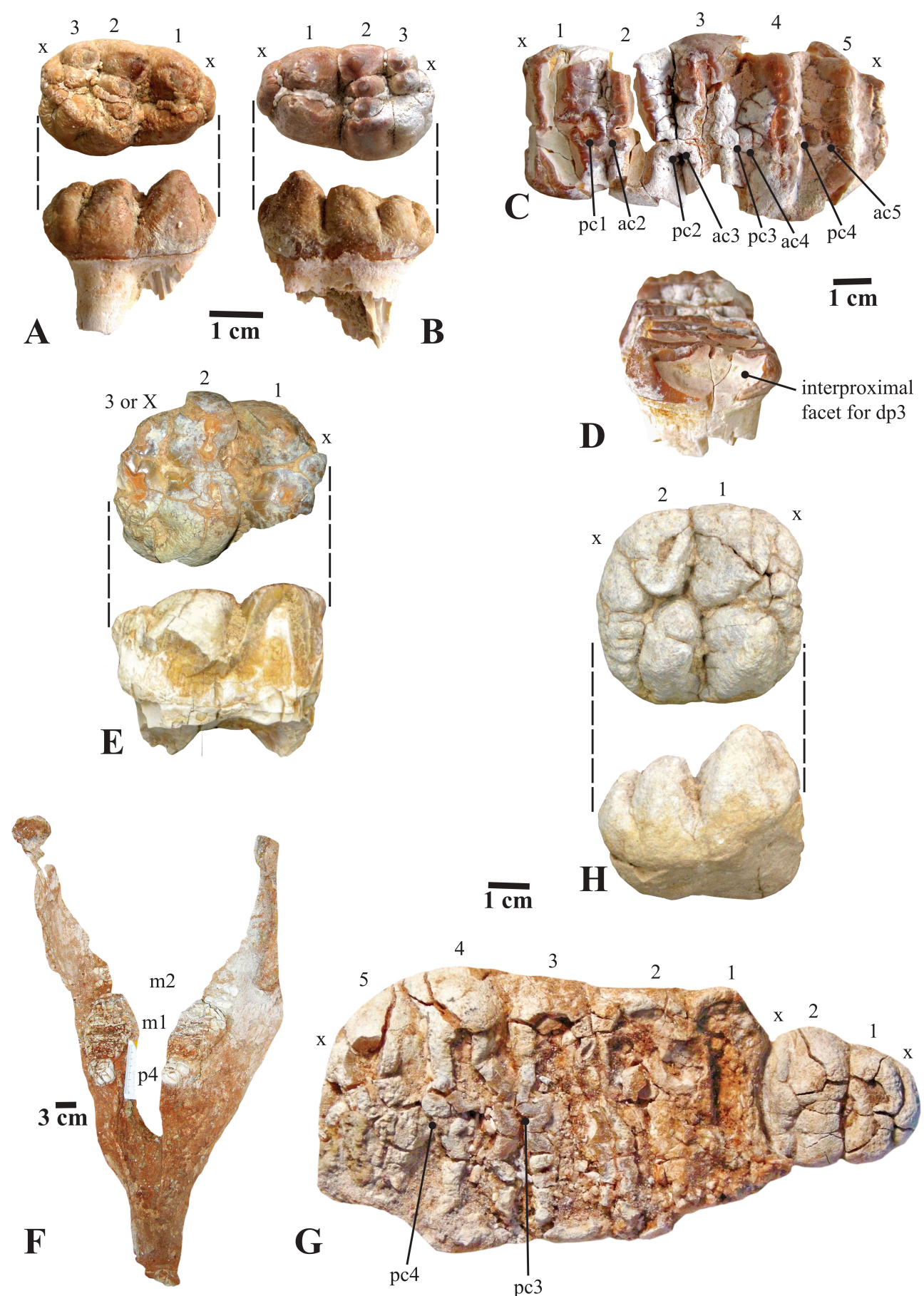

$\overline{\mathrm{cm}}$
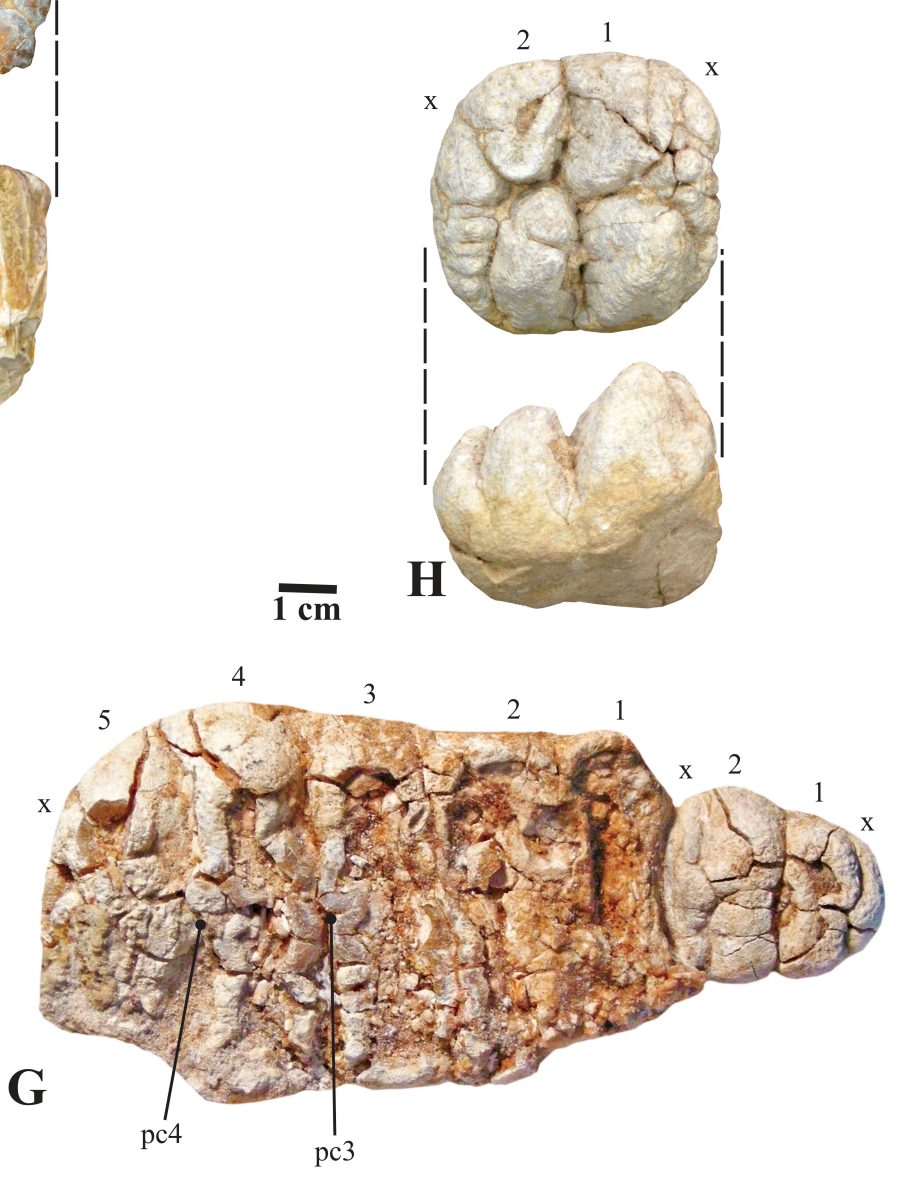
Fig 10.3
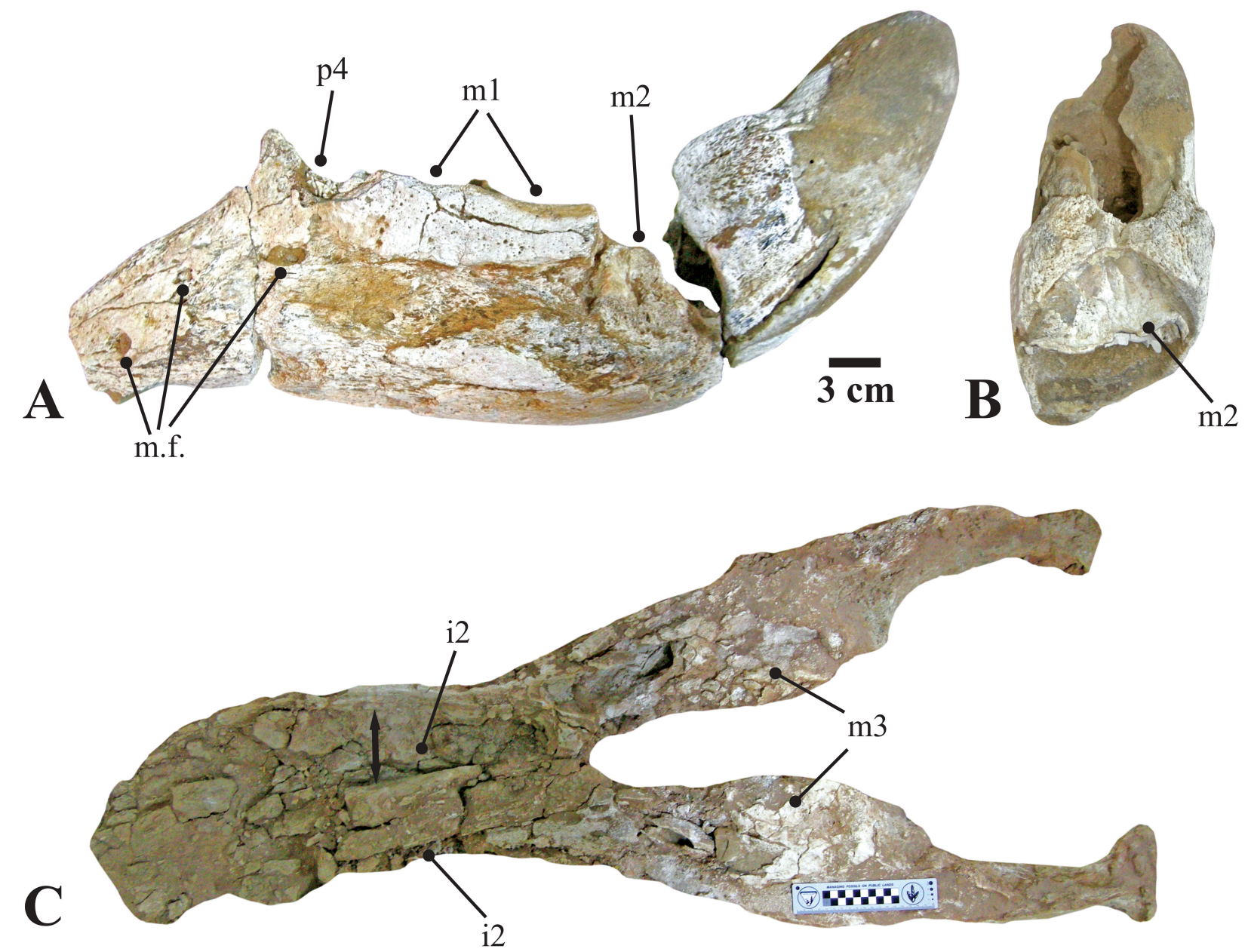
Fig 10.4

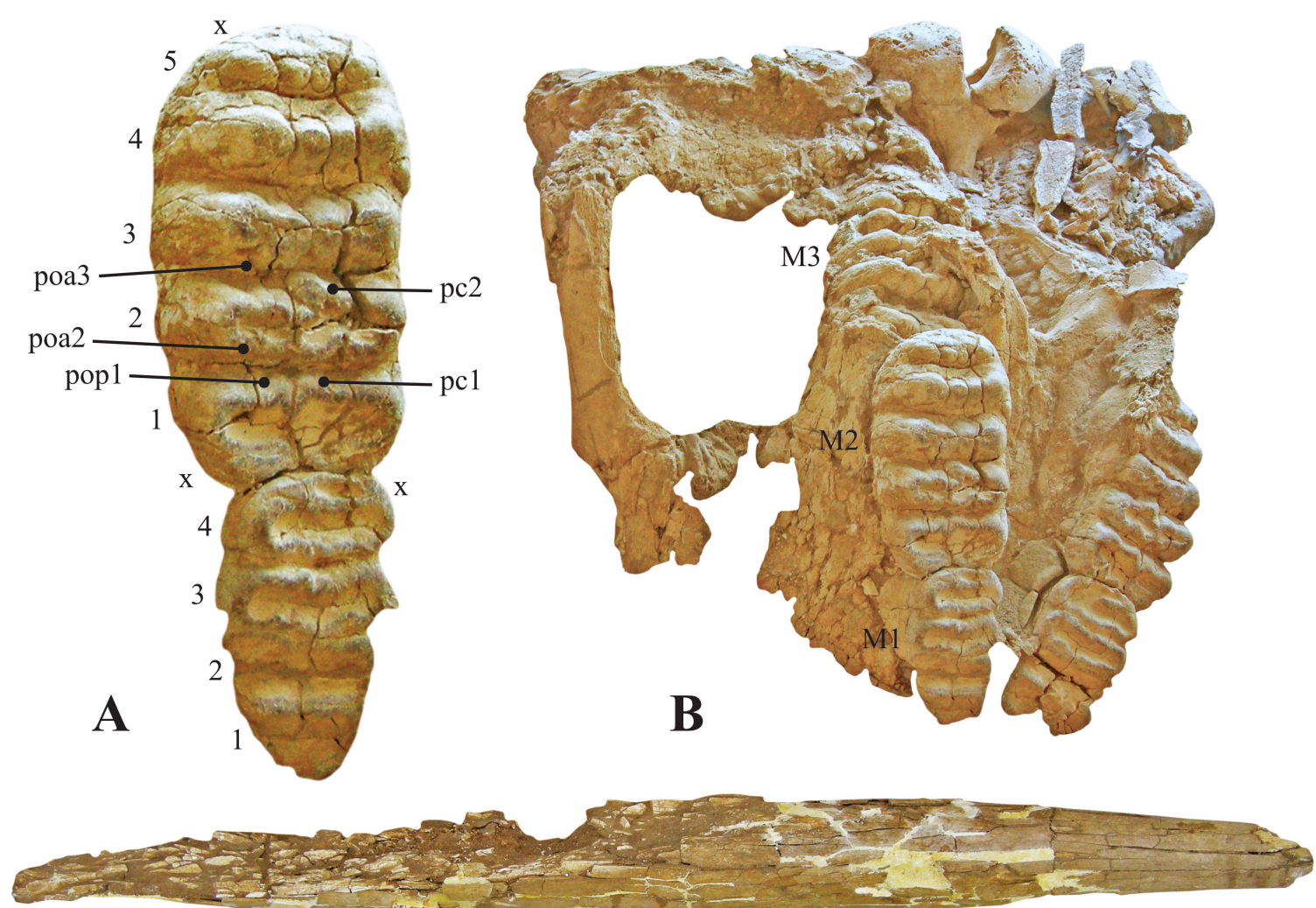

C

$3 \overline{\mathrm{cm}}$

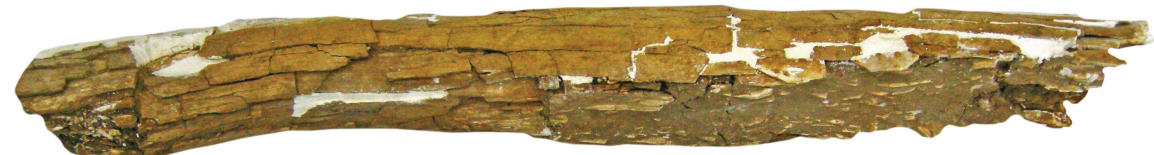

D

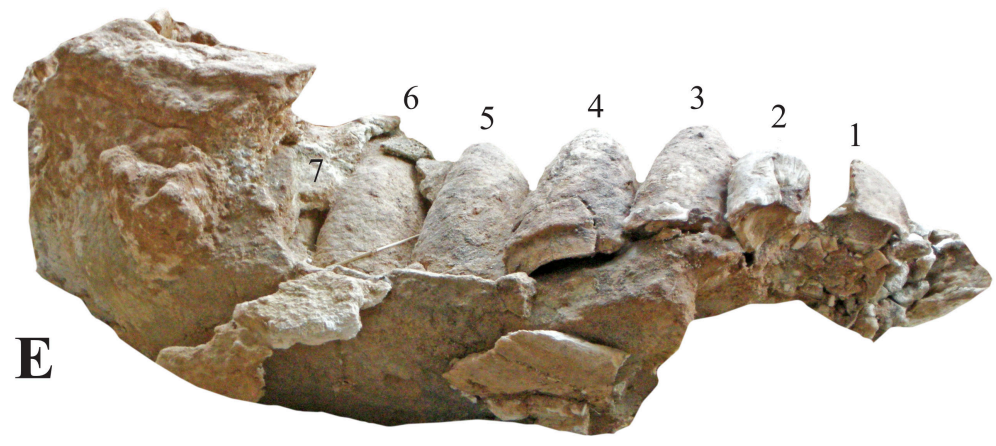


Fig 10.5

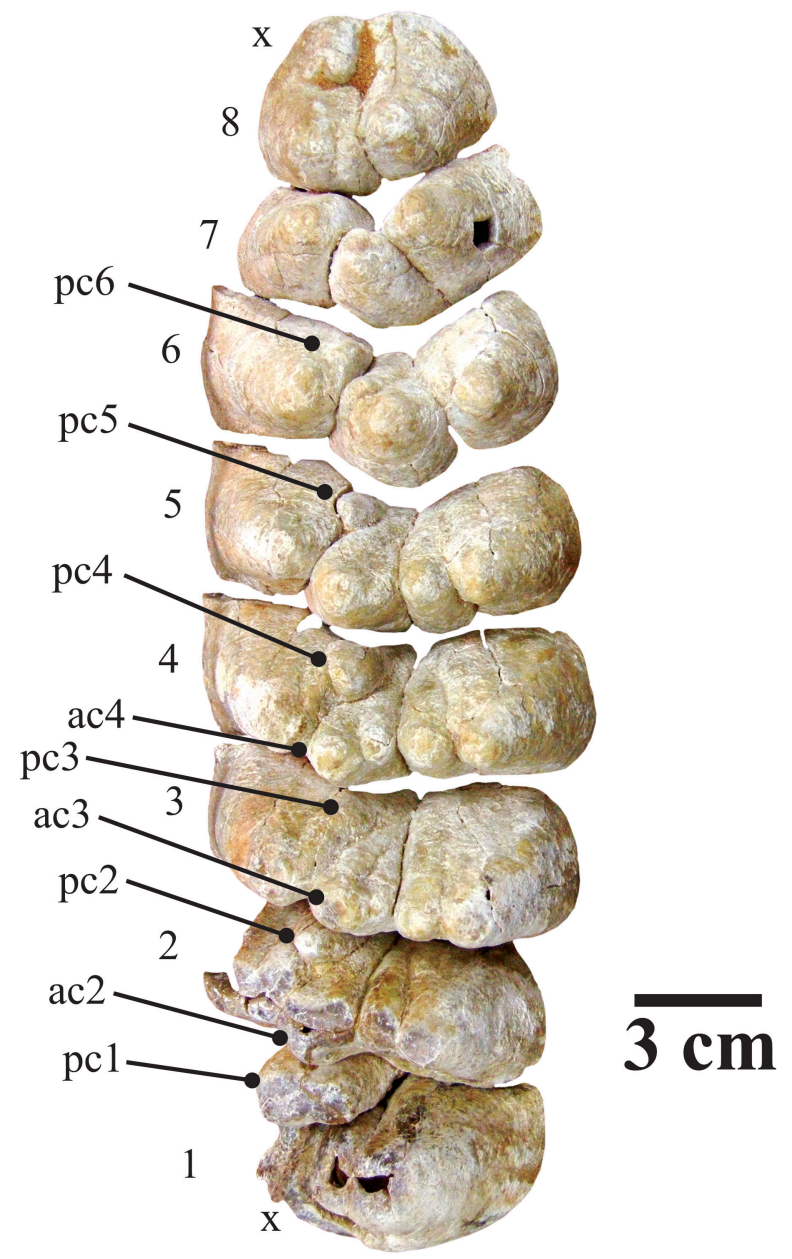


Fig 10.6
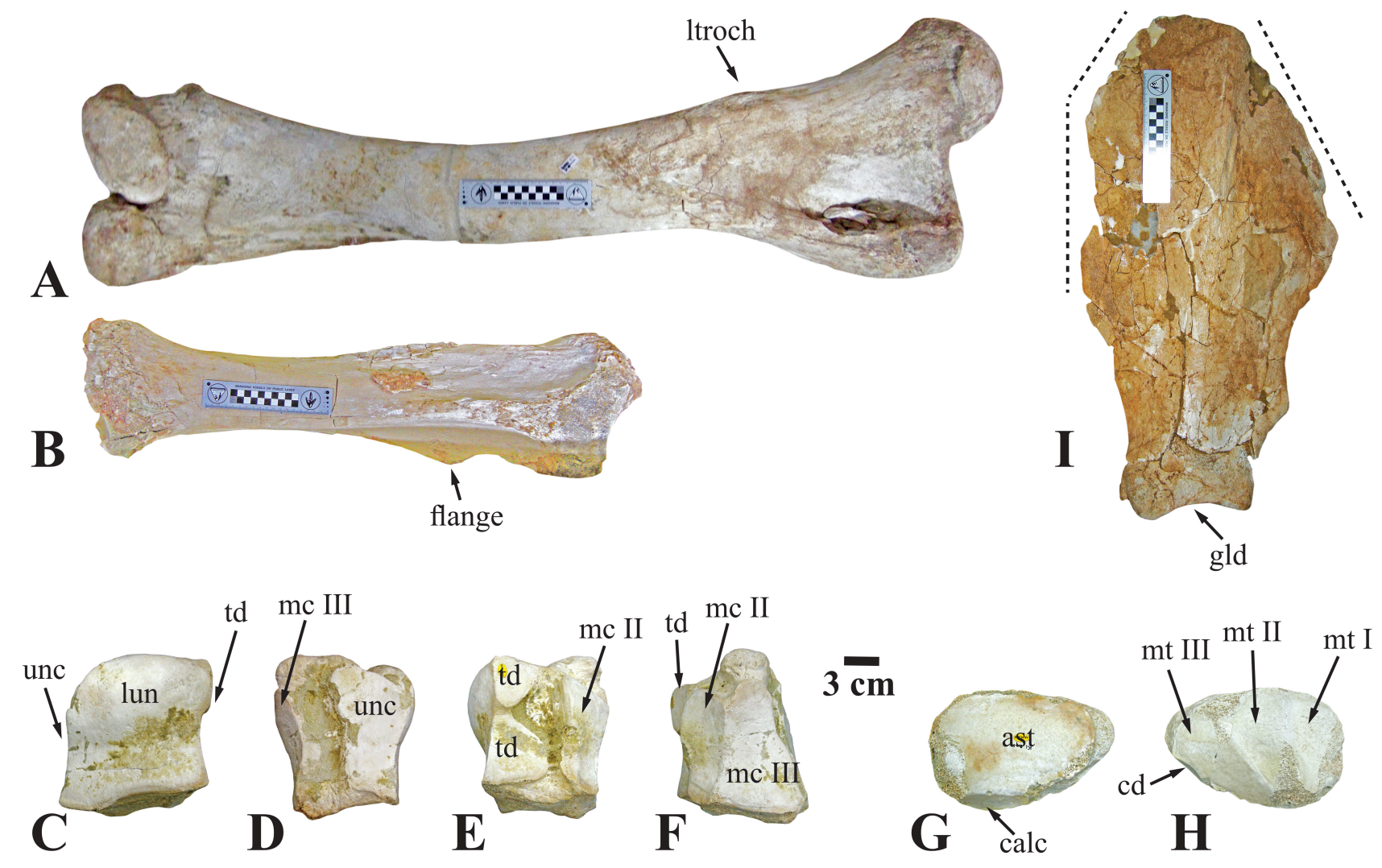
Fig 10.7
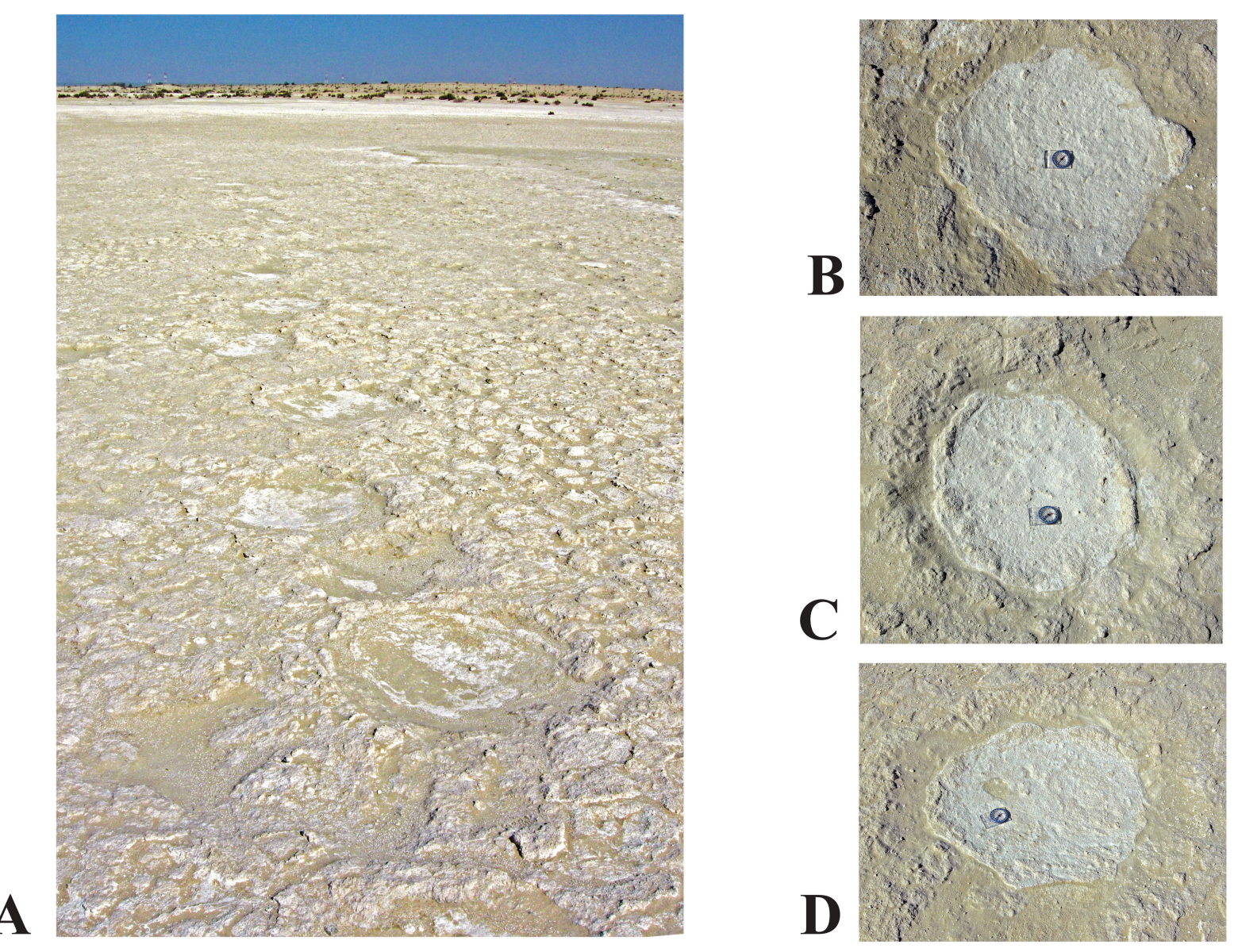